Microscopic Anatomy

of the Digestive System of the Chicken 



\section{Microscopic Anatomy \\ of the Digestive System of the Chicken}

by M. LOIS CALHOUN, M.S., D.V.M., Ph.D.

Professor and Head Department of Anatomy School of Veterinary Medicine Michigan State College 
Copyright, 1954, by The Iowa State College Press. All rights reserved. Composed and printed by The Iowa State College Press, Amos, Iowa, U.S.A.

Library of Congress Catalog Card Number: $54-7658$ 
SF $767 . P 6$

C $128 \mathrm{mZ}$

c. 1

\author{
To \\ H. L. Foust \\ Friend, Adviser \\ and
}

Educator 



\section{Preface}

The sustaining demand for reprints of this original work and the increasing importance of the poultry industry has prompted us to bring this work up to date and publish it as a reference book. Most of the original plates were used, with the addition of a few new ones to clarify particular points.

The initial assistance of Dr. H. L. Foust, formerly Head of the Veterinary Anatomy Department at Iowa State College, is gratefully acknowledged. Sincere appreciation also is extended to the Iowa State College Library. The author is indebted to Miss Esther M. Smith, Bacteriology Department, Michigan State College, for the preparation of the new plates, and to Clyde Douglass for technical assistance.

M. Lois Galmoun 



\section{Contents}

Review of Literature . . . . . . . . . . . 1

Mouth . . . . . . . . . . . . . . 2

pharynx . . . . . . . . . . . . . . . 3

Salivary Glands . . . . . . . . . . . . . . . 4

Esophagus . . . . . . . . . . . . . . 5

Crop . . . . . . . . . . . . . . . . 6

Proventriculus . . . . . . . . . . . . . . . . 7

Ventriculus . . . . . . . . . . . . . . . 9

Small Intestine . . . . . . . . . . . . . . . . . 11

Caeca . . . . . . . . . . . . . . . . 13

Rectum . . . . . . . . . . . . . . . 14

Cloaca . . . . . . . . . . . . . . . . 14

Anus . . . . . . . . . . . . . . . . . 15

Liver . . . . . . . . . . . . . . . . . 15

Gall Bladder . . . . . . . . . . . . . . . . 16

Pancreas . . . . . . . . . . . . . . . . 17

Bursa Cloacae . . . . . . . . . . . . . . . 18

Diverticulum . . . . . . . . . . . . . . 20

Gross Anatomy . . . . . . . . . . . . 21

Materials and Methods . . . . . . . . . . . 29

Results . . . . . . . . . . . . . 29

Beak . . . . . . . . . . . . . . . . . 29

Mouth Cavity . . . . . . . . . . . . . . . . 31

Tongue . . . . . . . . . . . . . . . . 33

Salivary Glands . . . . . . . . . . . . . . 38 


\section{x Contents}

Pharynx . . . . . . . . . . . . . . . 43

Esophagus . . . . . . . . . . . . . . . 43

Crop . . . . . . . . . . . . . . . . 47

Junction of Proventriculus and Esophagus . . . . . . . . . 47

Proventriculus . . . . . . . . . . . . . . . 49 49

Junction of Proventriculus and Gizzard . . . . . . . . . . 53

Gizzard (Ventriculus) . . . . . . . . . . . . . . 53

Section Between Gizzard and Duodenum . . . . . . . . . . 60

Small Intestine . . . . . . . . . . . . . . . . . 60

Caeca . . . . . . . . . . . . . . . . . 65

Rectum . . . . . . . . . . . . . . . . 70

Cloaca . . . . . . . . . . . . . . . 70

Anus . . . . . . . . . . . . . . . 70

Liver . . . . . . . . . . . . . . . . 75

Bile Duct . . . . . . . . . . . . . . . 76

Gall Bladder . . . . . . . . . . . . . . . 76

Pancreas . . . . . . . . . . . . . . . 82

Pancreatic Duct . . . . . . . . . . . . . . . 82

Bursa Cloacae . . . . . . . . . . . . . . . 82

Yolk Sac . . . . . . . . . . . . . . . 85

Yolk Stalk . . . . . . . . . . . . . . . . 85

Discussion . . . . . . . . . . . . . 90

Summary . . . . . . . . . . . . . . . 95

Literature Cited . . . . . . . . . . . . . 97

Additional References.............. . . 103 


\section{Microscopic Anatomy}

\section{of the Digestive System of the Chicken}

A study of the microscopic anatomy of the entire digestive tract of the chicken (Gallus domesticus) at different ages has never been undertaken. The author has never seen a related work illustrated with photomicrographs. These features added to the large compilation of literature included herein should make this a valuable source of reference to the anatomist. ${ }^{1}$ It should be of added value to the English-speaking anatomist since previous to this time the more complete works were written in the German language.

This study was also considered with the idea that it would help solve a problem which has long confronted the pathologist. Since he is concerned with the effects of disease on organs, it is hoped that this paper will give him a standard for comparison.

\section{REVIEW OF LITERATURE}

Literature concerning the microscopic anatomy of the digestive tract of the bird is quite voluminous, but with few exceptions [Zietschmann (1911) and Bradley and Grahame (1951)] no author included the entire tract with all its appendages. In many cases the work covered chiefly gross anatomy with an occasional reference to the microscopic structure. Authors dealing with the gross anatomy alone included Huxley (1878), Wiedersheim (1907), Kingsley (1917), Johnston (1920), Kaupp (1921), Latimer and Osborn (1923), and Ellenberger and Baum (1943). Baum (1930) has made quite a complete study of the lymph system of the digestive tract of the chicken. Sturkie (1954) has in-

${ }^{2}$ The original was a thesis submitted to the Graduate Faculty of Iowa State College in July, 1931, in partial fulfillment of requirements for the degree Master of Science and was published in the Iowa State College Journal of Science 7:261$382,1933$. 
cluded a limited amount of both gross and microscopic anatomy in his book on avian physiology. Strong (1939) published a bibliography of bird literature which includes all biological fields with a great many references to anatomy, histology, and embryology of the domestic fowl.

\section{Mouth}

Owen (1866), Wiedersheim and Parker (1897), Chauveau (1905), Zietschmann (1911), Kaupp (1918), Krause (1922), Schauder (1923), Grossman (1927), Boetticher (1928), and Bradley and Grahame (1951) spoke of the "horny" beak of the bird. Boetticher gave the time of beginning cornification as the sixteenth day of incubation. Krause gave a complete histological description of the beak. He divided it into four layers: bone, subcutis, cutis, and epidermis. Kingsbury et al. (1953) studied the histology of the beak of White Plymouth Rock embryos to follow the process of keratinization. According to Owen, "the beak consists of an upper mandible supported by the maxillary and premaxillary bones, and of a lower mandible formed by the lower jaw." Rosenstadt (1912), Schauder (1923), and Bütschli (1924) described the "Eizahn," a protuberance found on the upper beak of newly hatched chicks.

All recent authors are agreed that birds lack teeth. Blanchard (1860) described vestigial teeth in certain birds (parrots). Marsh (1881-82) stated that no true teeth had yet been found; and Ihde (1912), that further research along that line would be fruitless.

Owen (1866), Shufeldt (1890), and Marschall (1895) described the tongue muscles. Hollis (1901) gave particular attention to the skeleton of the tongue as associated with its function. Zietschmann (1911) described the relation of the shape of the tongue to the conformation of the mouth roof. Owen (1866), Wiedersheim and Parker (1897), and Ward and Gallagher (1926) spoke of it as a prehensile organ. Wiedersheim and Parker (1897), Schauder (1923), Bütschli (1924), Grossman (1927), and Otte (1928) described the tongue as pointed, especially horny at the apical end, and poor in muscle. Kaupp stated that the body of the tongue was made up of muscle and connective tissue. Schauder said the tongue corresponded to the form of the beak, while Marschall found that "the tongue of the chicken does not correspond to the form of the beak but has approximately the form of 
a shoe sole and is soft." Kallius (1905) dealt with the embryology of the tongue of the sparrow.

It is the common belief that the sense of taste is not enjoyed by the chicken, but taste cells were found on the tongue and hard palate by Schauder (1923), in the beak and tongue by Krause (1922), and in the mucous membrane between the sides of the lower beak by Otte (1928). Botezat (1904 and 1906) found that chickens have a sense of taste resembling that of mammals. He found taste organs in the throat region. According to Bradley and Grahame (1951) taste buds are not present in the chicken. McLeod (1939) stated that the existence of taste buds had been both affirmed and denied but that such endings, if present, are probably concerned with touch rather than taste. Moore and Elliot (1944) found 27-59 taste buds on the tongue of the pigeon, 70.7 per cent of which were on the dorsal and lateral surfaces of the soft portion of the tongue caudad from the tongue fold.

According to Heidrich (1905), Kaupp (1918), Grossman (1927), Ward and Gallagher (1926), Otte (1928), and Bradley and Grahame (1951), the roof of the mouth is the hard palate. Marschall (1895), on the contrary, stated that all birds lack a palate; Heidrich, Ward and Gallagher, and McLeod (1939), that a soft palate was absent. Heidrich gave a detailed histological description of the different layers in the wall of the mouth. Chamberlain (1944) found the lateral walls of the mouth cavity are covered with keratinized epithelium similar to that of the beak.

\section{Pharynx}

All authors agreed that there was no exact line of demarcation between the mouth cavity and the pharynx. Killian (1888) stated that "birds have no naso-pharyngeal cavity." Grossman (1927) set aside the transverse row of papillae on the root of the tongue as a "convenient" mark for separating the two cavities while Heidrich (1905) designated a row of papillae in the palate for the same purpose. McLeod (1939) considered the mouth and pharynx as one continuous cavity, which he termed oropharynx. He stated that its posterior extent reaches the level of the third cervical vertebra. Foust (1952) chose the most posterior row of palatine papillae and the row at the base of the tongue as a dividing line between the mouth and pharynx. Heidrich (1905) and Zietschmann (1911) stated that the mouth-pharyngeal cavity is 
covered by a "cutaneous mucous membrane." The latter added that a stratum corneum was found only on the roof of the mouth and on the caudal part of the dorsum of the tongue. Bradley and Grahame (1951) mentioned a stratified squamous epithelium lining the whole of the mouth and pharynx. Zietschmann did not find any muscularis mucosae in the mouth-pharyngeal cavity while Heidrich described it as beginning in the pharynx. Gadow (1891b) said that the pharynx was thin-walled; Heidrich, that it had no muscle, while Thomson (1923) designated the pharynx as a muscular region at the back of the mouth. Otte (1928) stated that instead of a soft palate a strong musculature was present. According to Schauder (1923), there were no voluntary muscles in the mouth except in the tongue.

Heidrich (1905) and Zietschmann (1911) described macroscopic papillae which have a matrix belonging to the tunica propria. Zietschmann stated that in the anterior part of the roof of the mouth there was little lymphoid tissue but that it increased posteriorly until the maximum was reached in the region of the opening of the Eustachian tubes. Killian (1888) has designated a certain area of adenoid tissue as "throat tonsil," especially in the region of the openings of the Eustachian tubes between the epithelium and the throat glands.

\section{Salivary Glands}

All authors who discussed the mouth parts at all mentioned salivary glands. Heidrich (1905), Zietschmann (1911), and Holting (1912) wrote the most complete works on the subject. The first two agreed, except on two points. Heidrich found basket cells while Holting did not, and Heidrich perceived some change in the gland according to the physiologic state while Holting failed to do so. Zietschmann differed from Heidrich on three points. Heidrich gave fifty as the number of openings of the lateral palatine glands and ten to fifteen openings for the anterior submaxillary gland, while Zietschmann gave "approximately one hundred" for the former and forty for the latter. Heidrich found muscle fibers in the gland capsule, and Zietschmann did not. Bradley and Grahame (1951), in their work, referred to Heidrich. Kovacs (1928) found the salivary glands to be uniformly constructed, in contrast to Heidrich, who described three different forms. Owen (1866), Marschall (1895), and Chauveau (1905) described them 
as being little developed. McLeod (1939) found salivary gland tissue abundant in the chicken.

Other authors mentioned them briefly: Browne (1922), "true salivary glands are absent"; Thomson (1923) mentioned their role in lubrication; Schauder (1923) "numerous glands purely mucous"; and Grossman (1927) spoke of several glands being in the submucous tissue producing a mucous secretion which did not contain a digestive enzyme. Schauder gave the location of all the glands but did not include the histology of them. Halnan (1949) described the salivary glands as branched tubular glands. Kaupp (1918) gave the location of angular, sublingual, and palatine glands. Otte (1928) spoke of the first two and, in addition, the submaxillary and the spheno-pterygoideae salivary glands. Bütschli (1924) mentioned particularly diffuse glands of the tongue. Owen mentioned the following: "folliculi lingualis," "glandulae sublinguales," "glandulae submaxillares," "glandulae anguli oris," "folliculi preglottidei," 'folliculi post-nasales," and "amygdalae." Cholodkowsky (1892) described the glands of the lower mandible and the "glandula angularis oris." Wiedersheim and Parker (1897) compared the lingual and palatine glands of the bird to those of the reptiles. Chodnik (1948) studied the cytology of the salivary glands in relation to feeding. He found that the cells go through a physiological cycle coincident with the alternate accumulation and discharge of the mucous contents. Zietschmann described elastic fibers in the connective tissue propria in which the glands lie, as well as in the gland capsule itself. Leasure and Link (1940) made a study of the saliva of the hen.

\section{Esophagus}

In general, the esophagus has been described as a very elastic tube extending from the pharynx to the proventriculus and containing at its entrance into the thorax a dilatation called the crop. Kupfer (1908) used the term pharynx instead of esophagus to designate the part from the back of the mouth to the proventriculus. There are, however, two markedly contrasting views as to its structure. Barthels (1895), Heidrich (1905), Kaupp (1918), Browne (1922), Batt (1925), Kovacs (1928), Otte (1928), and Bradley and Grahame (1951) spoke of the outer layer of muscle as a longitudinal one, while Owen (1866), Gadow (1879), Gazin (1888b), Newton (1893-97), Marschall (1895), Zietschmann 
(1911), and Otte (1928) mentioned an outer transverse or circular muscle layer. Heidrich observed that smooth muscle began quite a distance anterior to the esophagus.

Zietschmann (1911), Schauder (1923), and Kovacs (1928) found an esophageal tonsil near the lower extremity of the esophagus.

Another difference in opinion was manifested as to the number of layers in the wall. Kupfer (1908), Zietschmann (1911), and Otte (1928) said three; Marschall (1895), Batt (1925), and Grossman (1927), four; and Newton (1893-97), five.

The esophagus was described quite briefly by the following authors: Wiedersheim and Parker (1897), Browne (1922), Thomson (1923), Bütschli (1924), Ward and Gallagher (1926), and Grossman (1927). Schreiner (1900) and Schauder (1923) mentioned chiefly the Iongitudinal folds of the mucous membrane, smooth muscle, a longitudinally arranged elastic tissue sheath besides the muscularis mucosae, and the mucous glands. Of particular note in Barthels' (1895) work were "border cells," a detachment of the marginal edge of the mucosa.

Klein (1871) and Rubeli (1890) dealt with the structure, and Schumacher (1926) with the structure and development of the mucous glands. Batt (1925) -stated that the mucous glands were most numerous in the upper esophagus. Michalka (1924) found pavement epithelium in the glands of the esophagus. Ivey and Edgar (1952) described the histogenesis of the esophagus and crop of the chicken.

\section{Crop}

It was agreed that the crop had the same general structure as the esophagus. Marschall (1895), Wiedersheim and Parker (1897), Chauveau (1905), Kaupp (1918), Browne (1922), Schauder (1923), Batt (1925), Ward and Gallagher (1926), and Otte (1928) merely stated that mucous glands were present. Barthels (1895) found no glands in the diverticulum of the crop. Schreiner (1900) found glands only on the "back side." According to Kupfer (1908) "the ventral surface of the crop and the side parts in the ventral surface are free from glands." Owen (1866) described "muciparous follicles" as being larger and more numerous than those of the esophagus. Gadow (1891b) found the crop to have a glandless lumen, and Kovacs (1928) found glands in the dorsal wall. Browne (1922) found them most 
numerous near its openings. Schauder (1923) wrote that the middle part of the ventral crop wall had no glands. Klein (1871) and Bradley and Grahame (1951) found them absent in the crop. Zietschmann quoted Barthels, Gadow, and Schreiner on the matter of mucous glands and said in addition that the crop lacked lymphoid tissue. Mayberry (1935) followed the gross development of the crop of the chick embryo from the seventh to twenty-first day.

\section{Proventriculus}

Bischoff's (1838) work brings forcibly to one's mind the advancement made in histology in the last century. A quotation from his work follows: "The mucous membrane of the proventriculus which is present here and which is separated from the little sacs is in the form of small pyramidal pouches or villi in which I could not observe any epithelium but only a granular structure. ... If one sections it with a fine pair of scissors and flattens it out...."

In general the proventriculus was described as having a mucous membrane lined with simple columnar epithelium and containing in the tunica propria superficial tubular glands, a muscularis mucosae next, and between it and the lamina muscularis were the deep propria glands [Zietschmann (1911), Bradley and Grahame (1951) ]. In contrast to this, Batt (1925) described the deep propria glands as being between the muscularis mucosae and the epithelium. There were differences of opinion as to the structure of the glands. Browne (1922), Batt (1925), Grossman (1927), Otte (1928), and Bradley and Grahame (1951) described the deeper glands as tubular. According to Cazin (1887b and 1888a), the glands were "by no means tubular." Cazin (1887c) mentioned them as "culs-de-sac." Kovacs (1928) stated that the deep glands were sac-formed. Schreiner (1900) and Zietschmann (1911) found them to be multilobar. Recent papers on the proventriculus have all included a description of the macroscopic papillae containing a cavity into which the deep glands empty [McLeod (1939), Ellenberger and Baum (1943), Chamberlain (1944), Elias (1945), and Sisson and Grossman (1953) ]. Wilczewski (1870) stated that the glands increased in size near the esophagus and decreased near the gizzard, while Marschall (1895) found the glands to decrease at both extremities. According to Gadow (1891b), glands were located in approximately 
fifty scattered rows. Newton (1893-97), Wiedersheim and Parker (1897), and Ward and Gallagher (1926) mentioned particularly the large amounts of glandular tissue in the proventriculus. Dawson and Moyer (1948) described elongated threadlike argentophile cells scattered over the surface of the lobules or arranged radially between the tubules of the chicken proventriculus. Chodnik (1947) described the deep glands as tubular and found the superficial columnar epithelium similar to the intestinal epithelium. He found some transitional neck cells between the two.

Kovacs (1928) stated that "the glands may be likened to fundus glands"; Browne (1922), that the proventriculus was "analagous to true stomach in mammals"; Bütschli (1924) compared the proventriculus to the cardiac portion of the mammalian stomach; Batt (1925) stated that there were no acid or peptic cells in the proventriculus but that they resembled the parietal cells of mammals; and Kaupp (1918) found them similar to the fundic glands of the horse.

The same differences of opinion as to the muscle layers existed here as in the case of the esophagus. Cazin (1888b) admitted that a longitudinal layer might be seen on the outside of the external circular layer. He also found the muscularis mucosae to contain both a longitudinal and transverse layer. Zietschmann (1911) made this statement, "Of twenty-six investigated kinds of birds, only one, Iotames calidris, lacked the longitudinal layer." In Oppel's (1895) work on the muscular layers of the proventriculus he described an outer longitudinal layer (often rudimentary) and an inner circular layer comprising the lamina muscularis and an inner longitudinal layer and the muscle around the glands as making up the muscularis mucosae. Zietschmann stated that the outer longitudinal layer ended at the beginning of the gizzard.

Zietschmann (1911) described a lymphocytic infiltration of the propria which included many eosinophils. Hässe (1866) found only a trace of elastic elements visible. Laroche (1926-27) quoted Cazin. Swenander (1902) studied Gallus domesticus in comparison with other birds. Owen (1866), Chauveau (1905), and Schauder (1923) gave slight consideration to this organ. Schreiner's (1900) work included quite a detailed cytological study of the epithelium. At the point of the folds, prismatic cells had a height of thirty microns. The basal part of the cell was small, granular, and contained an oval nucleus. Other vacuolated cells which took a deeper stain were described. He also found the 
cells to diminish in height as the fold widened. Hibbard (1942) studied the Golgi apparatus in both proventriculus and gizzard of chicken embryos and growing chicks.

According to some authors there is a so-called "intermediary piece" between the proventriculus and the gizzard. Batt (1925) said it was analogous to the mammalian pylorus. Hässe (1866), Cazin (1886b), Zietschmann (1908), Schauder (1923), and Kovacs (1928) stated that it was characterized by the lack of the deep propria glands of the proventriculus. Cazin (1886a) described the tubular glands as longer than the surface glands of the proventriculus. Cazin (1888b) stated that the exudate was more complex. Schauder and Zietschmann agreed that it lacked the hornified layers of the gizzard, while Kovacs characterized it by its keratinized layer. Marschall (1895) found a sphincter of circular muscle fibers separating the proventriculus and gizzard, while Bradley and Grahame (1951) designated the constriction only as a demarcation. Bütschli (1924) stated that a "clear intermediary piece is seldom inserted between the two sections."

\section{Ventriculus}

Most authors agreed on the general structure of the gizzard: its peculiar musculature, a thin submucosa, and the mucous membrane with its glandular layer and its keratinized secretion forming an inner layer. Owen (1866), Gadow (1891b), Newton (1893-97), Wiedersheim and Parker (1897), Cornelius (1924), Grossman (1927), Otte (1928), and Bradley and Grahame (1951) described the internal layer as hard, thick, yellowish, horny, and keratinized. Zietschmann (1911) said it was falsely called a horny layer and Hedenius (1892) described it as a keratinoid layer medial between keratin and albumin. Cazin (1887a) stated that it was not analagous to tegumentary coverings.

According to Bütschli (1924), this layer was strata-like and contained cast-off cells, and Hässe (1866) mentioned parallel lines in it. Cazin (1886b) described a "secretion in the form of colonnades between which the secretion from the superficial epithelium is poured."

Browne (1922) spoke of a "horny epithelium" and stated that there were no true glands present. Otte (1928) said that the true mucous membrane lay under the inner membrane and that the glands therein resemble the stomach glands of mammals. Schauder (1923) and Kovacs (1928) compared them to pyloric glands of 
mammalian stomachs. Hässe (1866), Cazin (1886b), and Bütschli (1924) described the glands as tubular; Cazin (1886a), as long cylindrical culs-de-sac. Hässe (1866), Zietschmann (1911), Cornelius (1924), and Kovacs (1928) mentioned the cluster arrangement of the glands.

Cazin (1888b) stated that the cells were arranged obliquely to the axis of the tube. Pilliet (1886) stated that the gland cells were not cylindrical and Zietschmann (1911) that they were cubical to flat. Wiedersheim (1872) described secretion cells which appeared on the edge of the glands in profile. He also included a microscopic study of the secretion cone and secretion hook, the two latter being in contact with the cell itself. Zietschmann stated that the glands were shorter where the mucosa was thinner. He also found elastic tissue to be confined to an area beneath the gland region. Cazin (1885), in writing of the development of the cornified layer, stated that on the sixteenth day of incubation the glands approached the adult form. Dawson and Moyer (1948) found a few oval or triangular argentophile cells in association with the epithelium of the gland tubules. Kaupp (1917) stated that walls of gizzards of granivorous birds were very thick, while Magnan (1911a) contended that the muscle masses were reduced to a minimum. Batt (1925) mentioned a thin outer longitudinal muscle layer. Sisson and Grossman (1953) described three muscle layers - inner oblique, middle circular, and outer longitudinal.

Both Garrod (1872), who wrote a paper on the mechanism of the gizzard, and Ashcraft (1930), in writing of the activities of the alimentary canal of the fowl, stated that in hunger the proventriculus and gizzard were vigorously and continually contracting, but they did not discuss the minute structure of the gizzard. Bauer's (1901) work on the histology of the gizzard was chiefly done on the duck. Cazin (1887b) dealt with the embryonal development.

Marschall (1895) and Kaupp (1918) designated a valve and Otte (1928) a fold in the mucous membrane as separating the gizzard from the duodenum.

Marschall (1895) also stated that the wall of the gizzard became thinner as it approached the duodenum. According to Bradley and Grahame (1951), the keel of the gizzard contains striated muscle. They described coarse transverse striations varying from $25 \mu$ to $90 \mu$ apart. According to their reports, nuclei crossed by the striations were distorted. According to Zietschmann (1911), the 
border zone was rich in lymphocytes. Oppel (1896-1914) stated that this transitional zone corresponded to the pyloric region of mammals. Zietschmann called it the pyloric gland zone of the gizzard.

According to Oppel (1896-1914), one cannot speak of a pyloric sphincter between the ventriculus and the duodenum. He also stated that the circular muscle of the intestine could be considered as a continuation of the diminished muscles of the ventriculus. Zietschmann (1911) stated that the surface of the gland layer in this intermediary portion became uneven and the glands were farther apart and took on an aspect of villi. Oppel described the glands in this areas as club-shaped and curved at their lower end - not a beginning of Lieberkühn's glands. Kovacs (1928) described an alteration of the glands and the presence of lymphoid infiltration possessing follicular character.

\section{Small Infestine}

Zietschmann (1911), Batt (1925), and Clara (1926a) agreed in general on the structure of the small intestine (duodenum included): the mucous membrane was lined with simple columnar epithelium interspersed with goblet cells; the villi were tongueshaped, longer and more numerous in the duodenum; a submucosa in which the blood vascular system was contained; and two layers of muscle - an inside muscularis mucosae, the middle circular and outer longitudinal layers of the lamina muscularis. Cloetta (1893) stated that there was no submucosa and that the blood and lymph vessels were in the tunica propria.

Two bile ducts and three pancreatic ducts opening into the duodenum were described for the chicken by all authors with the exceptions of Batt (1925), who described one bile duct and two pancreatic ducts, and Chamberlain (1944) and Sisson and Grossman (1953), who indicated that there might sometimes be only two pancreatic ducts. According to Gadow (1879), the entrance of the ducts into the intestine was marked by a small warty projection which contained a valve.

Newton (1893-97) described a villus as a structure containing a prolongation from the submucosa, a lacteal, arteries and veins, and smooth muscles. Bujard's (1906) work indicated a change in the villi according to age. Clara (1927b) found the villi to present a picture of geometric regularity upon cross section.

Cloetta (1893) described the epithelial cells of the glands as 
being smaller than the epithelial cells of the villi. He also found goblet cells nearer the tip of the villus as the age of the birds increased. Chodnik (1947) found the goblet cells of the domestic fowl to differ from those of mammals in that they always presented the form of a neatly shaped goblet. He followed the cycle of the Golgi apparatus and mitochondria in relation to secretory activities. Ackert et al. (1939) found that the numbers of goblet cells in a unit area $(122 \mu \times 10 \mu)$ along the side of the villi of the duodenum varied from 2.9 in a 2-day-old chick to 9.0 in a 320 day-old bird. Birds of 71 and 124 days had 9.3 and 10.7 goblet cells per unit area, respectively. Zietschmann (1911) found that the epithelial cells contained a cuticular border. Moog (1950) observed that the striated cuticular border of the duodenum of chicks up to 2 days old exhibited large quantities of alkaline phosphomonoesterase indicating a powerful phosphatase-synthesizing mechanism present at hatching. Bradley and Grahame (1951), Greschik (1922), and Clara (1926b and 1927a) agreed that there were cells of Paneth, while Cloetta doubted their presence, All authors with the exception of Kaupp were agreed that Brunner's glands were lacking. Kaupp (1918) made the following statement: "Openings of simple intestinal tubular glands, the duodenal glands, or the glands formerly known as Brunner's glands, are located between the villi."

Otte.(1928) described Peyer's patches in the bird intestine, and Retterer and Lelièvre (1910a) found areas having the appearance of Peyer's patches.

Zietschmann (1911) found that elastic fibers were not demonstrable in the gland layer and were comparatively few in other layers. Batt (1925) described a layer of white fibrous tissue between the outer longitudinal and the inner circular muscle. According to Batt there were valvulae conniventes present; also lymph nodules were fewer in the remainder of the small intestine than in the duodenum.

Browne (1922) made the statement that the intestine was uniform in caliber throughout, while Cloetta (1893) and Otte (1928) found the duodenum to have a wider lumen.

Gadow (1891b), Newton (1893-97), and Thomson (1923) mentioned the ileo-cecal valve, and Zietschmann (1911), an iliac sphincter. Marschall (1895), Wiedersheim and Parker (1897), Ward and Gallagher (1926), and Grossman (1927) described the small intestine briefly. 


\section{Large Intestine}

The term large intestine was seldom used. Some used the term colon, while others used the term rectum to include the portion from the caeca the cloaca. Still others used the terms combined - colon and rectum. McLeod (1939) suggested the term colorectum. In this paper rectum will be used to refer to this portion.

\section{Caeca}

Zietschmann (1911) and Looper and Looper (1929) made the most complete studies of the caeca. The general structure corresponded to the small intestine. According to Eberth, as reported by Oppel (1897), Zietschmann (1911), and Kaupp (1918), there was an elevation in the caeca about two to four millimeters from their origin. Muthmann (1913) found so-called "caecal tonsils." Looper and Looper found that lymph nodules first appeared at about fourteen days in the tunica propria two millimeters from the origin of the caeca, and in the tunica propria and submucosa of the blind ends. Prior to this age, the lymphoid tissue was scarce and diffuse. Berry (1900) found lymphoid tissue diffused throughout the mucosa. Looper and Looper (1929) and Bradley and Grahame (1951) described many lymphoid nodules in the caeca. Batt (1925) stated that there were "few small lymphatic nodes" and Zietschmann (1911) that follicles seldom appear.

Looper and Looper (1929) found the muscularis mucosae to be absent in many places, while Batt (1925) stated that it was well developed.

Looper and Looper found many eosinophils throughout the wall, and Muthmann (1913) stated that cells with large granules were present in large quantities. Bittner (1924) and Otte (1928) divided the caeca into three parts: a neck with many villi, a middle portion with few villi, and the vescicular blind end which was thin walled and free from villi. Zietschmann (1911) and Browne (1922) stated that the villi were short or absent in the dilated portion. According to Batt (1925), the mucous membrane was thrown into folds which gave the appearance of villi.

Oppel (1895) referred to Eberth as finding ciliated epithelium in the folds and extending into the glands. Maumus (1902) attempted to verify this but failed. He concluded they were probably artifacts.

Zietschmann (1911) found goblet cells to be lacking in spaces where lymphoid tissue was numerous. 
Other important facts brought out by Looper and Looper (1929) were: the submucosa was occupied by or obliterated by lymph nodules where the lymphoid tissue was present in the tunica propria; circular layers of muscle were displaced by lymphoid tissue in the blind end; reticular connective tissue fibers extended into the circular muscle layers and encircled the fibers; most important of all, the mucosa of the distal two-thirds underwent a degenerative change as fowls became older. The regression involved the atrophy of the epithelium and glands accompanied by the appearance of lymphoid tissue. This had, in turn, been replaced by sclerotic fibrous tissue in the blind ends of the caeca in a 3-year-old specimen.

Marschall (1895), Wiedersheim and Parker (1897), Schauder (1923), Ward and Gallagher (1926), Grossman (1927), and Otte (1928) gave slight consideration to the caeca. Maumus and Launoy (1901), Röseler (1929), and Mangold (1931) dealt primarily with the physiology of these organs.

\section{Rectum}

Regarding the structure of the rectum, little has been said beyond the fact that it was very similar to the small intestine. Owen (1866) stated that the villi of the rectum were coarser, shorter, and less numerous than those of the small intestine. Greschik (1912), on the contrary, found them to continue the same height to the anus. Zietschmann (1911) in describing the "cloacal end of the rectum" agreed with Owen (1866) and added that the villi "afterwards take on the greatest length of anywhere in the intestine." Marschall (1895) and Grossman (1927) described numerous villi with glands emptying between them. Greschik mentioned simple tubular glands, and Zietschmann stated that the glands were longer than in the rest of the intestine. Zietschmann (1911), Greschik (1912), and Clara (1926a) found lymphoid tissue in the rectum. According to Greschik, the submucosa was weakly developed and in many cases not apparent.

\section{Cloaca}

Bütschli (1924) found a sphincter marking the limitation of the rectum. Owen (1866) and Otte (1928) made the statement that the rectum terminated in a valvular circular orifice. Kaupp (1917) agreed with them by saying that there was a strong oblique fold of the mucous membrane where the large intestine emptied 
into the cloaca. According to Retterer (1885) and Jolly (1915), there was no demarcation between the two.

Gadow (1891a), Schauder (1923), Thomson (1923), Bütschli (1924), Ward and Gallagher (1926), and Bradley and Grahame (1951) described three compartments in the cloaca. The most anterior was named coprodaeum, the middle one urodaeum, and the posterior one proctodaeum. Retterer (1885) spoke of a "rectal. vestibule" in describing the anterior compartment. Owen (1866) stated that the rectum terminated in a rudimentary urinary bladder. McLeod (1939) did not favor the use of the terms coprodaeum, urodaeum, and proctodaeum because he felt such divisions did not coincide with the facts. He preferred to describe the cloaca as a tubular cavity incompletely divided into an anterior functional and a posterior non-functional part by a circular fold of mucous membrane. Bennett (1944) studied 181 White Leghorn chickens and found three compartments: the coprodaeum, which was the largest; the urodaeum, the smallest; and the proctodaeum. He found definite folds separating the urodaeum from the other two compartments. Foust (1952) also described three compartments in the cloaca as did Chamberlain (1944) and Sisson and Grossman (1953).

According to Gadow (1891a), the coprodaeum had the same mucous membrane as the rectum, and Zietschmann (1911) described a one-layered epithelium extending as far as the anal opening. Bradley and Grahame (1951) found Paneth cells to the end of the proctodaeum.

\section{Anus}

Retterer (1885) described a sphincter of smooth muscle outside of which was a voluntary transverse cloacal muscle. Marschall (1895) described the anal opening as an oblique slit, while Gadow (189la) stated that it was a round opening.

\section{Liver}

Few writers have given much attention to the microscopic anatomy of the bird liver. Krause (1922) studied the liver of the pigeon as representative of the livers of birds and found it to be very similar to the mammalian liver. He found indications of changes in the cells according to the secretory condition. Batt (1926) also noted the similarity to the mammalian liver. Zietschmann (1911) stated that the liver of the bird had a smaller lobule 
design than the mammal. According to him central veins were lacking. Batt stated central veins and a portal system were present.

Chodnik (1948) stated that the liver of the domestic fowl is much simpler than that of mammals and has no true lobular structure. He also found prominent morphological changes in both Golgi material and mitochondria to be connected with cellular activity and secretory phenomena. Elias and Bengelsdorf (1952) have presented some new ideas on the structure of the liver. They believe that the vertebrate liver is a "solid mass of hepatic cells, perforated by more or less cylindrical lacunae which contain the sinusoids." The hepatic plates or lamina are walls separating these sinusoids. In chickens they found all hepatic plates to be two cells in thickness. They described the chicken liver as "sacculosinusoidal." These same authors also found the nuclei of the liver cells of germ-free chickens from the Lobund Laboratory at Notre Dame University to be the most extremely basally or parietally located of any vertebrate specimen examined. Bradley and Grahame (1951) found the chicken liver to be simpler than mammalian liver and more like reptile liver. According to their work the liver cords form columns arranged in a tubular manner about a bile capillary.

Zietschmann (1911) found elastic fibers only in the vessel walls. Batt (1926) described a scant reticulum in the liver of the bird. Shore and Jones (1889) described the liver parenchyma as dense with obscure cell outlines. In young chickens the cell structure was clearly tubular with five rows of cells to the tubules. Shore and Jones further indicated that there was no distinction between interlobular and intralobular vessels. Shore (1890-91) found the liver cells of baby chicks to be excavated by spaces for oil droplets. He suggested a relationship between the color of the liver and the yolk. Doyle and Mathews (1928) stated that the color of the liver changed from the yellow of the baby chick liver to the red or maroon of the adult liver by the time a chick was a week to ten days old. Dalton (1933) studied the mitochondria and Golgi network in the hepatic cell of the chick.

\section{Gall Bladder}

The wall of the gall bladder, as described by Zietschmann (1911), consisted of an adventitia with many blood vessels and some lymph follicles, an outer longitudinal and inner circular 
muscular layer, and a mucous membrane with many folds. The propria was filled with lymph cells. According to him, "the surface epithelium resembles that of the liver," and the surface was pouched and contained short crypts. Otte (1928) found many tubulose glands in the tunica propria. Bradley and Grahame (1951) described only a thin longitudinal muscle layer in the gall bladder.

The structure of the ducts was similar to that of the gall bladder. The ducts contained, according to Zietschmann (1911), a one layered cylindrical epithelium, while goblet cells and special glands were lacking.

\section{Pancreas}

Zietschmann (1911) found the pancreas to differ little from that of the mammal. Pugnat (1897) described three lobes, each possessing a distinct excretory duct. Clara (1924) described, in addition to the two lobes in the loop of the duodenum, a splenic lobe. He did not find a separate excretory duct for it. Clara found this splenic segment to be of a lobular structure, while the other two were not. According to Pugnat, the pancreas was a ramifying and reticular tubulo-acinar gland. Krause (1922) described more islets of Langerhans in the dorsal lobe than in the ventral, while Clara (1924) and Nagelschmidt (1939) found more in the splenic lobe of the pancreas. According to Zietschmann, the islets of Langerhans showed nothing special in the bird, while Clara described a "pseudo-islet" similar in structure, but different in staining affinity. According to Batt (1926), they were smaller than the islets of the mammalian pancreas but similar in structure. Böhm (1904) did not find a pronounced accumulation of Langerhans cells. He did not find the islets to be set off from the surrounding pancreas, while Batt described a delicate fibrous capsule surrounding them. Lucas (1947) observed that the islets were small in both relative amounts and size in embryos and young chicks. As chicks grew older he found a rapid increase both in size of islets and in amount of islet tissue. He reported the islets to vary in size from one with a few cells up to one $363 \mu$ by $458 \mu$. Lucas also observed a lumen as large as $23 \mu$ in diameter in one islet. Other islets presented only a slitlike lumen. Clara (1924) had previously found a lumen in the islets of birds. Lucas also found intranuclear inclusions in the islands of the White Leghorn chicken. They first appeared in birds of 30 days and were present in 75 per cent 
of those between the ages of 31 to 40 days. By the time the birds had reached 101 days or more, 99.4 per cent of them exhibited inclusion bodies. He found no relation to sex, lymphomatosis, or other possible causes.

Oakberg (1949) made a study of the ratio of pancreas weight to body weight and determined the number of islets in different areas in various aged White Leghorn chickens. He confirmed the observations of Nagelschmidt (1939) and Miller (1942) that there were two types of islets in birds, one "dark" composed of alpha and delta cells, the other "clear" made up of beta and delta cells. Miller made his observations on the pigeon pancreas. Oakberg (1949) found from 150 alpha islets at one day to 2,000 at 100 days and 3,500 beta islets at one day to 40,000 at 300 days regardless of sex. More alpha islets were present in the proximal portion of the body of the pancreas. Beta islets were distributed throughout. Alpha islets were larger in males. In the splenic lobe both types of islets were larger than in the body of the pancreas. Clausen (1953) in studying the phylogeny of the islet of Langerhans found two types of islets in birds, clear islands of the regular type and dark islands which are specialized organs similar to "Gangorgane," a secondary island found in some lower forms. Chodnik (1947 and 1948) made a study of the relation of zymogen granules, Golgi material, and mitochondria to the physiological activity of the pancreas cells. Zietschmann (1911), Krause (1922), and Bradley and Grahame (1951) found few centroacinar cells, while Pugnat (1897) stated that there were no centro-acinar cells. According to Pugnat, the pancreatic cell was small. Batt found basket cells forming a reticulum about the acinar cells. Zietschmann described scant elastic tissue between the gland tubes.

Zietschmann (1911) stated that the pancreatic ducts were similar in structure to the bile ducts. Batt (1926) mentioned a simple columnar epithelium lining the main duct and involuntary muscle fibers in its walls.

\section{Bursa Cloacae}

The bursa cloacae (bursa of Fabricius) has given rise to much speculation in regard to its function. According to Retterer and Lelièvre (1913b), it had previously been given the names: egg reservoir, third caecum, anal gland, anal pouch, urinary vessel, bladder, genital apparatus, seminal vesicle, prostate, Cowper's 
gland, and one author even described it as a pouch characteristic of the female which received the sperm of the male. Microscopically this organ has in general been described as having a serosa, a muscular tunic of smooth fibers, and a mucous membrane of longitudinal folds made up of a mass of lymphoid and epithelial tissue. Retterer (1885) described a thick serosa; Osawa (1911), a thin serosa; and Jolly (1915) stated that the capsule was made up of a thin connective tissue layer and a thin smooth muscle layer. Gadow (1891a) also mentioned the smooth muscle. Retterer (1885) found the exterior muscle layer longitudinal and the internal transverse, while Osawa found the opposite arrangement. Retterer (1885) stated that there might be as many as 40 to 50 follicles in a single fold. Jolly (1915) stated that there were 12 to 14 folds in the chicken.

There were two opposing views on the structure of the follicle: one that there was a connective tissue network and blood vessels in the medullary portion [ Stieda (1880), Retterer (1885), and Osawa (1911) ]; the other that connective tissue and blood vessels did not penetrate the medullary part [ Wenckebach (1889 and 1896) and Schumacher (1903) ]. Retterer and Lelièvre (1910a) described an abundance of elastic fibers in the "interfollicular walls."

There were some differences of opinion regarding the epithelium. Jolly (1915) mentioned only cylindrical epithelium; Schumacher stated that the epithelium varied from cuboidal and tall columnar to pseudostratified columnar; according to Osawa (1911) the epithelium was stratified with the surface layer cylindrical. Wenckebach (1889) did not find any goblet cells. Gadow (1891a) found few goblet cells in the epithelium of the bursa cloacae.

Forbes (1877) could not find a valve or flap over the opening to the bursa cloaca. Retterer (1885) stated that the posterior face of the uroanal fold overhung the opening into the bursa in the murre (Uria aalge).

Retterer (1893), Jolly (1910, $1911 \mathrm{la}$, and 1913a), and Retterer and Lelièvre (1913a) concerned themselves chiefly with the development of the bursa cloacae. Retterer and Lelièvre $(1910 \mathrm{~b}$ and 1913b) stated that the medullary portion was of epithelial origin. According to Retterer (1885), its size at its maximum development was probably $2.5 \mathrm{~cm}$. in length, $2 \mathrm{~cm}$. in width, and $1.5 \mathrm{~cm}$. in thickness. Jolly (1913b) stated that the beginning of 
involution coincided exactly with the appearance of sexual maturity, while Riddle (1928) found involution usually complete coincident with sexual maturity. According to Kaupp (1918), Schauder (1923), Otte (1928), and Bradley and Grahame (1951), its maximum growth was reached between four and five months. Bittner (1924) compared the bursa cloacae to an acorn at five months and a hemp seed or a pea at one year. Others such as Gadow (1891a), Marschall (1895), Wiedersheim and Parker (1897), Thomson (1923), and Ward and Gallagher (1926) discussed its retrogression briefly. Jolly (1911c and 1915) wrote more in detail on the subject. On the matter of its physiological function, Boyden (1922) referred to Jolly (1911b), who ascribed to it a hematopoietic function. Jolly (1911b) and Jolly and Levin (1911) found that fasting had a rapidly degenerative effect on the bursa cloacae.

\section{Diverticulum}

The remnant of the yolk stalk was described as an appendage to the small intestine. Owen (1866), Retterer and Lelièvre (1910c), and Otte (1928) observed this diverticulum in many birds. Zietschmann (1911) stated that in all birds, except the goose, it disappeared completely after birth. Muthmann (1913) found it to remain during the entire life of the bird. Latimer (1924) and Bradley and Grahame (1951) found it to be constantly present in the chicken. Maumus (1902) stated that the cells lining the so-called third caecum were a continuation of the intestinal canal. Much lymphoid tissue was present. As age increased macrophages became numerous, the villi diminished, and the longitudinal muscle fibers near the blind end seemed to disappear little by little. Maumus made the statement that the disappearance of the muscle varied with the activity of the macrophages. Generally it began to disappear about the third month and had completely disappeared in the greater part of Gallinacea two months later.

The disappearance of the yolk sac itself was considered by Schilling and Bleecker (1928) to be almost complete by the fourteenth day. Schauder (1923) stated that it underwent involution at the sixteenth day in the chick. Latimer (1924) found the yolk sac, with one exception, up to and including the thirty-eighth day, and thereafter frequenly up to the two hundred thirty-seventh day. 


\section{GROSS ANATOMY}

Prehensile and masticatory organs are limited to an upper and lower beak. (P1. I-1).

The chicken possesses a hard palate which is separated from the pharynx by a row of papillae. (Pl. II-5). The nares (Pl. II-4) open through a longitudinal slit into the middle of the hard palate and the dorsal mid-portion of the pharynx.

The tongue (PI. II-12) is attached to the caudal part of the floor of the mouth and conforms to the shape of the beak. On its posterior part is a row of papillae. (Pl. II-13). The tongue muscles include lingual and hyoid muscles [Owen (1866) and Shufeldt (1890)].

The pharynx (P1. II-6) is a poorly defined area in the back of the mouth into which open the Eustachian tubes (Pl. II-8), esophagus (P1. II-11), larynx, mouth, and the nasal openings as described above. The aditus laryngis (Pl. II-16) presents no epiglottis.

The esophagus (Pl. I-5) is a long dilatable tube leading from the pharynx to the proventriculus with an outpouching, the crop (P1. I-6), at the entrance into the thoracic cavity.

The proventriculus (P1. I-7) appears as a dilatation of the esophagus at its posterior extremity but upon palpation is found to be thicker-walled and spongy. It opens after a narrow constriction at its posterior extremity into the muscular stomach, the gizzard or ventriculus.

The ventriculus (Pl. I-8) is oval, flattened laterally, and particularly prominent because of its musculature. This muscular mass is comprised of two pairs of muscles: the two thin musculi intermedii (Pl. I-10), one of which arises near the proventriculus and the other at the posterior end, are between the thick musculi laterales, (PI. I-9) which are part of the wall of the lumen. Both pairs have their insertion on a tendinous aponeurosis (PI. I-11) on the lateral side of the ventriculus.

The duodenum (P1. I-12), the fore part of the small intestine, forms a loop in which the main part of the pancreas lies. Three pancreatic and two bile ducts enter at a point approximating the junction of the duodenum with the remainder of the small intestine.

The jejunum and ileum (Pl. I-16), between which there is no line of differentiation, are arranged in coils supported by the mesentery. 


\section{GROSS ANATOMY}

Prehensile and masticatory organs are limited to an upper and lower beak. (Pl. I-1).

The chicken possesses a hard palate which is separated from the pharynx by a row of papillae. (Pl. II-5). The nares (Pl. II-4) open through a longitudinal slit into the middle of the hard palate and the dorsal mid-portion of the pharynx.

The tongue (P1. II-12) is attached to the caudal part of the floor of the mouth and conforms to the shape of the beak. On its posterior part is a row of papillae. (P1. II-13). The tongue muscles include lingual and hyoid muscles [Owen (1866) and Shufeldt (1890) ].

The pharynx (PI. II-6) is a poorly defined area in the back of the mouth into which open the Eustachian tubes (Pl. II-8), esophagus (Pl. II-11), larynx, mouth, and the nasal openings as described above. The aditus laryngis (P1. II-16) presents no epiglottis.

The esophagus (P1. I-5) is a long dilatable tube leading from the pharynx to the proventriculus with an outpouching, the crop (Pl. I-6), at the entrance into the thoracic cavity.

The proventriculus (Pl. I-7) appears as a dilatation of the esophagus at its posterior extremity but upon palpation is found to be thicker-walled and spongy. It opens after a narrow constriction at its posterior extremity into the muscular stomach, the gizzard or ventriculus.

The ventriculus (Pl. I-8) is oval, flattened laterally, and particularly prominent because of its musculature. This muscular mass is comprised of two pairs of muscles: the two thin musculi intermedii (P1. I-10), one of which arises near the proventriculus and the other at the posterior end, are between the thick musculi laterales, (Pl. I-9) which are part of the wall of the lumen. Both pairs have their insertion on a tendinous aponeurosis (Pl. I-lI) on the lateral side of the ventriculus.

The duodenum (P1. I-12), the fore part of the small intestine, forms a loop in which the main part of the pancreas lies. Three pancreatic and two bile ducts enter at a point approximating the junction of the duodenum with the remainder of the small intestine.

The jejunum and ileum (Pl. I-16), between which there is no line of differentiation, are arranged in coils supported by the mesentery. 


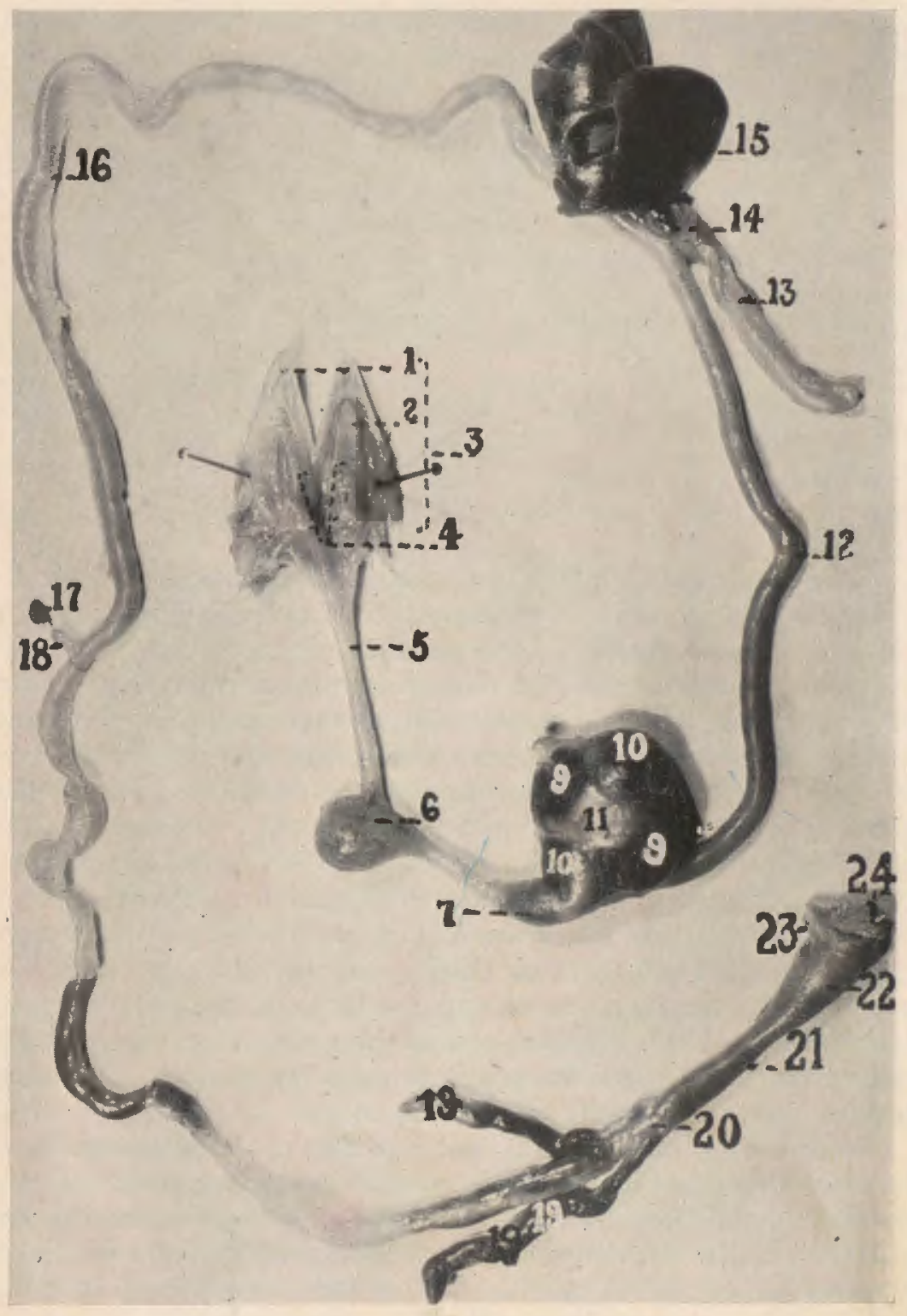


At a point about midway in the small intestine may be found the attachment of the stalk of the yolk sac (Pl. I-17) or its remnant (Pl. I-18) depending on the age of the chicken.

There is no line of demarcation between the colon and rectum, the two usually being considered as one, the rectum (Pl. I-21) .

At the junction of the small intestine and rectum (Pl. I-20) the paired caecae (Pl. I-19) are given off anteriorly. Each terminates as a blind sac which is larger than the constricted part near its origin.

The rectum terminates in the anterior portion of the cloaca. There is no line of demarcation except a gradual widening.

The cloaca (Pl. I-22) is divided into three parts: the coprodaeum into which the rectum empties; the middle part, the urodaeum, into which the ureters and genital ducts enter; and the external part, proctodaeum, from which the bursa cloacae (Pl. I-23) extends antero-dorsally.

The anus (Pl. I-24) is comprised of a prominent dorsal and a ventral lip which meet at each side forming a lateral commissure. If these lips are extended dorsoventrally, the anal opening will be seen as a vertical slit.

The liver (Pl. I-15) is a two-lobed organ lying posterior to the rudimentary diaphragm. Its posterior edges are quite noticeably notched. The gall bladder (PI. I-14) is located on its visceral surface, and from it the ductus cysticus carries the bile to the duodenum, while a second duct, the ductus hepaticus, comes directly from the left lobe and empties into the duodenum in close proximity to the first.

As mentioned the main part of the pancreas (PI. III-10, 11)

Plate 1 - Entire digestive tract of a baby chick. The duodenum was separated from the pancreas and the loop opened. The pancreas and liver were joined to the intestine
by the ducts.

1. Beak

2. Tongue

3. Mouth

4. Pharynx

5. Esophagus

6. Crop

7. Praventriculus

9. Mm. laterales

10. Mm. intermedii

11. Tendinaus aponeurosis of the ventriculus, or gizzard

12. Duadenum
13. Pancreas

14. Gall bladder

15. Liver

16. Jejunum and ileum

17. Yolk sac

18. Yolk stalk

19. Caeca

20. Junction of caeca and small intestine

21. Rectum

22. Cloaca

23. Bursa cloacas

24. Anus 


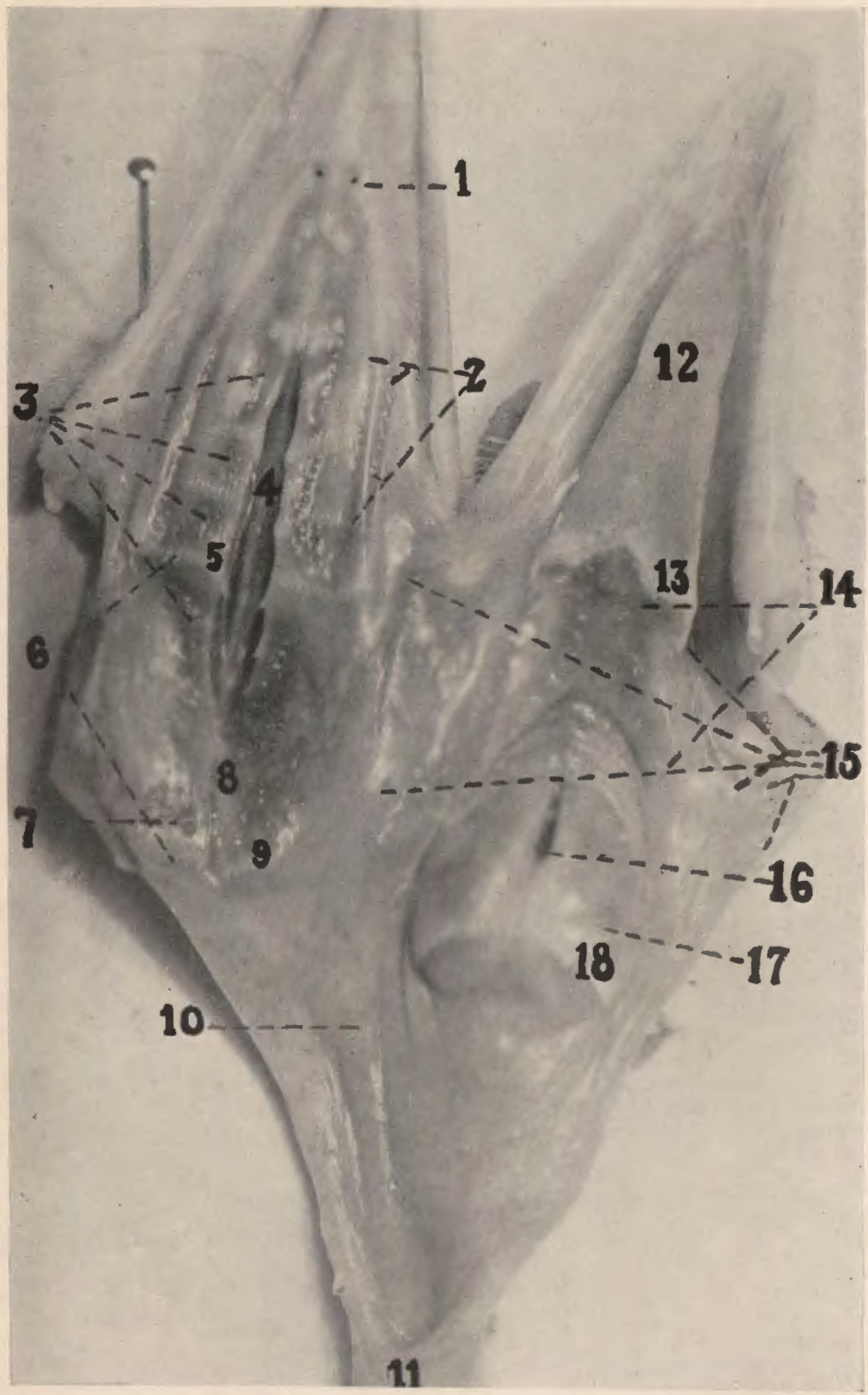


is located in the loop of the duodenum. The pancreas is composed of three lobes, the dorsal and ventral lobes located as described and a third much smaller lobe extending dorsally to the spleen. (PI. III-12).

Measurements of the digestive tract of five chickens were made and are included in Table 1, to show the relative lengths. By comparing the figures one may get an idea of the rate of growth.

TABLE 1

Growth Changes in the Digestive Tract

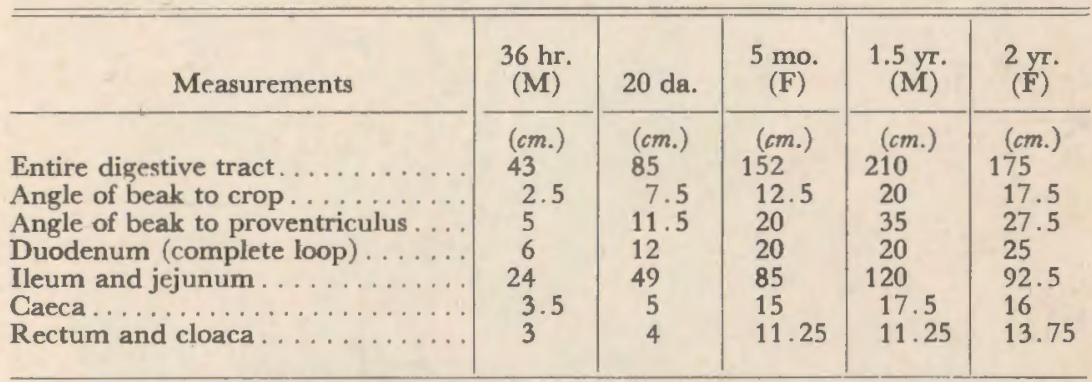

Marsden (1940) measured the intestines of 10 male and 10 female turkeys. The total length and the length of individual organs was longer in the male than in the female. The above data for the 11/2-year-old male and the 2-year-old female followed the same pattern.

Orr (1931) took measurements and computed averages on the intestines of 35 birds. The birds ranged in weight from 1200 to $1800 \mathrm{gm}$., 85 per cent of which were within a $200 \mathrm{gm}$. range. His results follow: the duodenum (measurements including the entrance of the bile and pancreatic ducts) , $25.3 \mathrm{~cm}$; the remainder of the small intestine, $104 \mathrm{~cm}$; entire small intestine, $132.5 \mathrm{~cm}$.;

Plate $\|$ - Mouth parts of the chicken.

1. Opening of the maxillary gland

2. Openings of the lateral palatine gland

3. Openings of the medial palatine gland

4. Nasal opening

5. Papillae separating mouth from pharynx

6. Pharynx

7. Openings of the sphenopterygoid gland

8. Opening of the Eustachian tubes

9. Pharyngeal papillae

10. Aditus esophagus with mucous gland opening on its surface
11. Esophagus

12. Tongue

13. Lingual papillae

14. Openings of the posterior lingual gland

15. Openings from the three parts of the posterior submaxillary gland

16. Aditus laryngis

17. Openings of the cricoarytenoid gland

18. Laryngeal papillae 


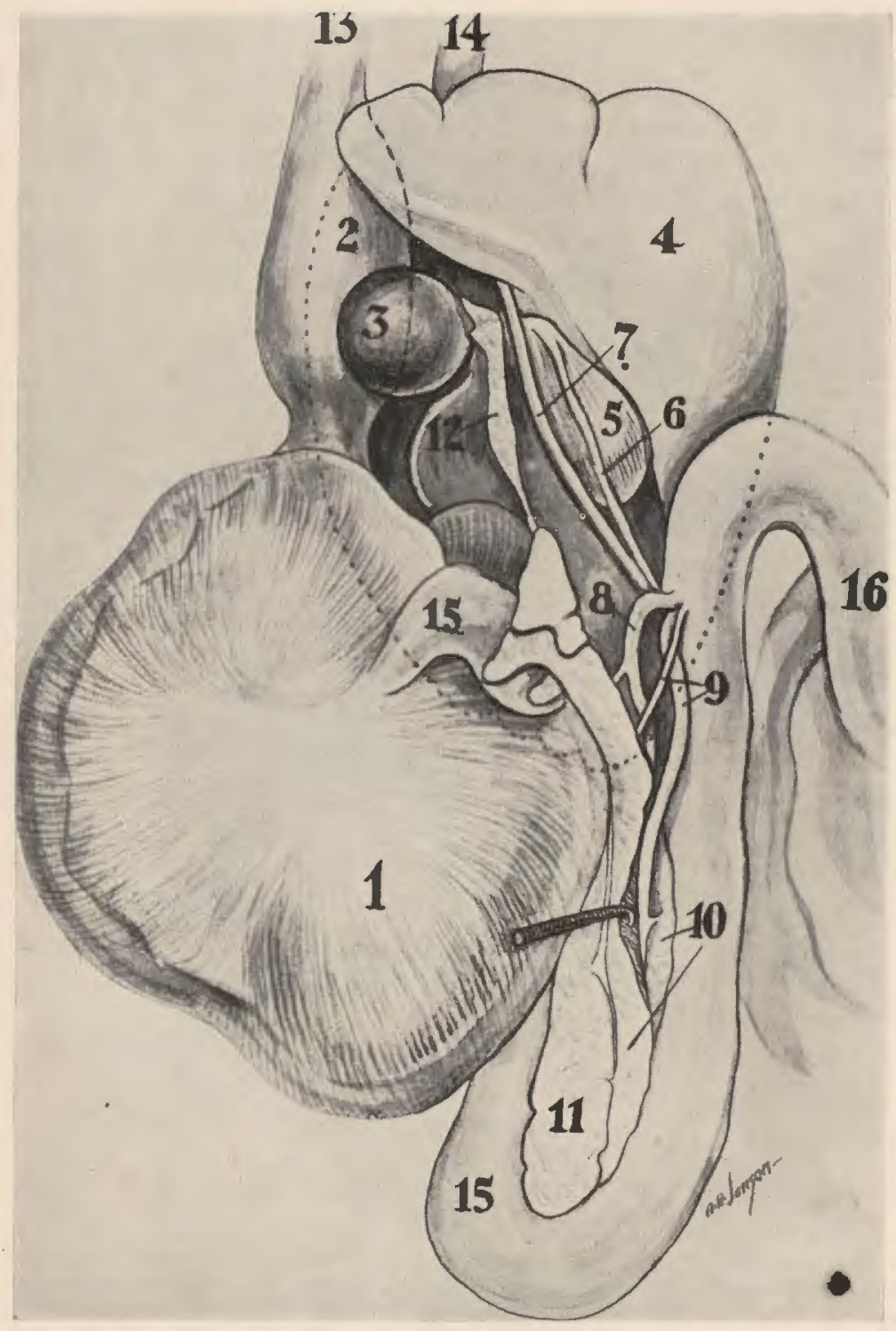


caeca, $14.4 \mathrm{~cm}$.; and "colon" (measured from the entrance of the caeca to the point where the rectum began to widen), $6.36 \mathrm{~cm}$.

Kersten (1912) made measurements on the intestine of 24 specimens ranging from 2 da. $3 \mathrm{hr}$. to $21 \mathrm{wk} .8 \mathrm{hr}$. (Table 2).

In a 3-week-old chick, Kersten found the length of the small intestine to be $72 \mathrm{~cm}$., while the writer found it to be $61 \mathrm{~cm}$. Likewise in a 5-month-old specimen, Kersten found the length of the small intestine to be $127.5 \mathrm{~cm}$. and the writer found it $105 \mathrm{~cm}$. The latter measurement by Kersten compares with Orr's figures $(132.5 \mathrm{~cm}$.) of the intestinal length. An average of the length of the two adult specimens of the intestine studied by the writer was $128.7 \mathrm{~cm}$. Other figures are similar: the duodenal length of the adult according to Orr was $25.3 \mathrm{~cm}$. and the writer found 22.5 $\mathrm{cm}$.; the length of the small intestine without the duodenum was $106.5 \mathrm{~cm}$. according to Orr, and $140 \mathrm{~cm}$. according to the author's observation; the caecal length as Orr gave it was $14.4 \mathrm{~cm}$. and the author found $16.5 \mathrm{~cm}$. According to Kersten, the caecal length in a 5 -month-old chicken was $16 \mathrm{~cm}$. and the author found it to be $15 \mathrm{~cm}$. In the 3-week-old specimen the figures for the caeca were similar, being $6.5 \mathrm{~cm}$. as Kersten gave it and $5 \mathrm{~cm}$. according to the author.

In the oldest specimen Kersten measured (21 weeks), the length of the "colon and rectum" was $9.5 \mathrm{~cm}$. In the adult specimens, Orr found the "colon" to be $6.36 \mathrm{~cm}$. in length.

Magnan (1911a) made the statement that the total surface of the body was 2.4 times the intestinal surface in granivorous birds (917 individuals, 12 species). In the same article M. Caullery criticized Magnan's work and said that the surface of the intestine from a physiological viewpoint should be its glandular surface and should take into consideration the villi and crypts.

Plate III - Photograph of a drawing to show the pancreas, the pancreatic ducts, and the bile ducts.

1. Gizzard

2. Proventriculus

3. Spleen

4. Liver

5. Gall bladder

6. Ductus cysticus

7. Ductus hepaticus

8. Pancreatic ducts from the dorsal pancreas
9. Pancreatic ducts from the ventral pan. creas

10. Ventral lobe of the pancreas

11. Dorsal lobe of the pancreas

12. Splenic lobe of the panereas

13. Esophagus

14. Vena cava

15. Duodenum

16. Small intestine 
TABLE 2

Length of the Intestinal Canal After Hatching

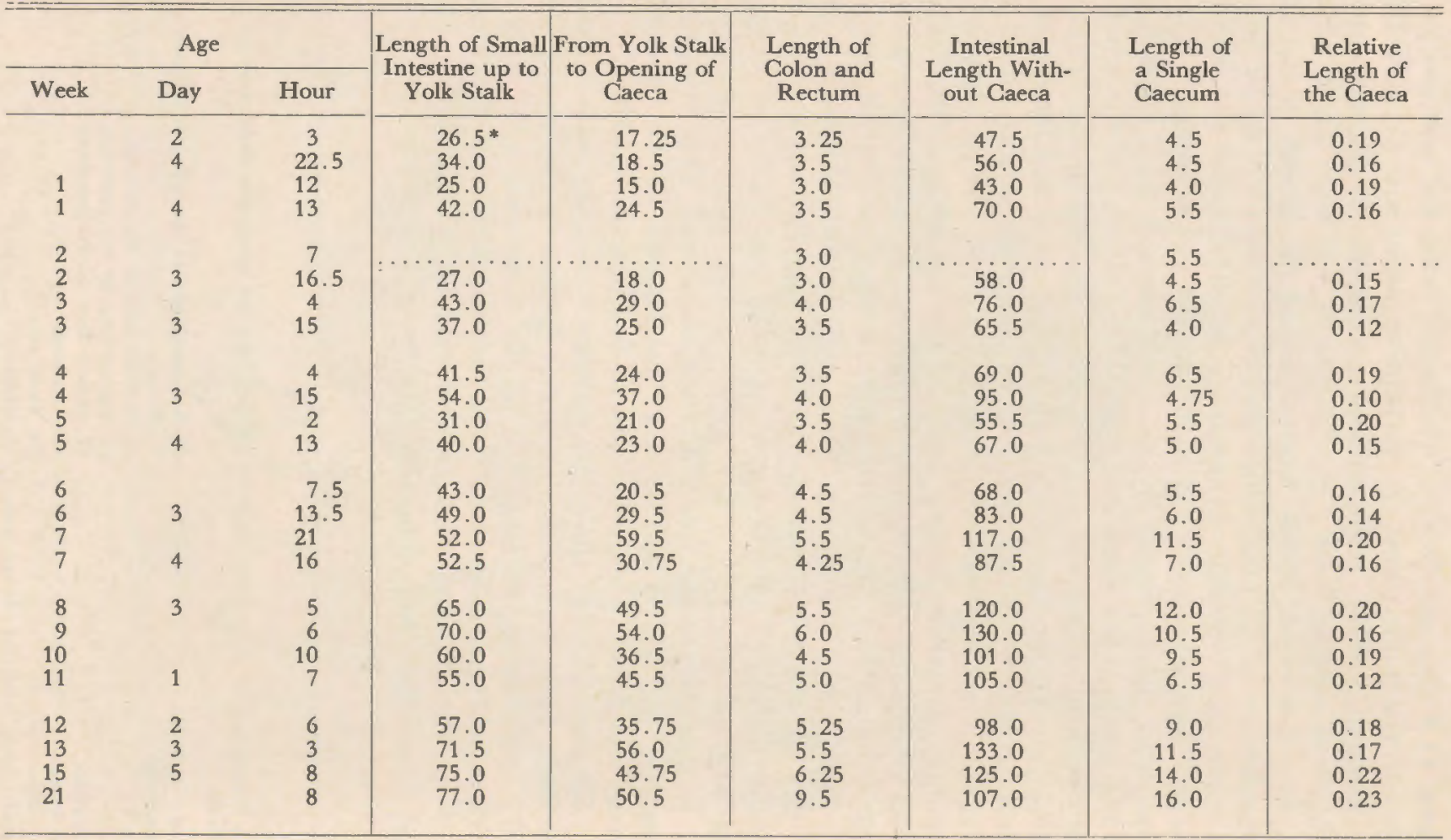

* All measurements in centimeters. 


\section{MATERIALS AND METHODS}

The specimen material was secured from one carcass each of chickens aged thirty-six hours (male), twenty days (sex unrecorded), five months (female), one and one-half years (male), and two years (female). Besides these, livers and some additional material were obtained from two groups of baby chicks. Several specimens of the bursa cloacae were obtained from other chickens. For the current revision, portions of several other specimens were utilized to check the original work and to verify the work of recent investigators.

The following methods were used: paraffin embedding with the exception of frozen sections of a specimen of each liver; Harris hematoxylin and eosin were used as a routine stain; Weigert's elastic tissue stain was used for elastic connective tissue; Van Gieson's picro-acid-fuchsin was used for white fibrous connective tissue; frozen sections of liver were stained with Scharlach $\mathbf{R}$ [alcohol-acetone method according to Mallory and Wright (1924) ]; mucin was demonstrated by Mayer's mucicarmine method as given by Hoepke (1930); keratohyalin granules were stained by Pasini's (1930) method; reticulum, according to Foot and Menard (1927).

In the experiments with the baby chicks the chicks were killed at stated intervals and a section of the liver stained for fat to determine at what age the fat began to disappear and how long it persisted.

\section{RESULTS}

Observations were made on the digestive tract from the beak to the anus, including all appendages. No differences existed in the digestive tract of either sex, so the matter of sex will not be referred to again.

\section{Beak}

The beak, as shown in Plate IV, Figure A, consisted of three layers, bone (11), corium (6), and epidermis (1). The bone in the upper beak was the os incisivum and in the lower the os dentale. A layer of periosteum was observed outside the bone. (Pl. IV, Fig. A-10).

The corium (P1. IV, Fig. A-6) extending from the periosteum to the epithelium was made up of connective tissue containing 


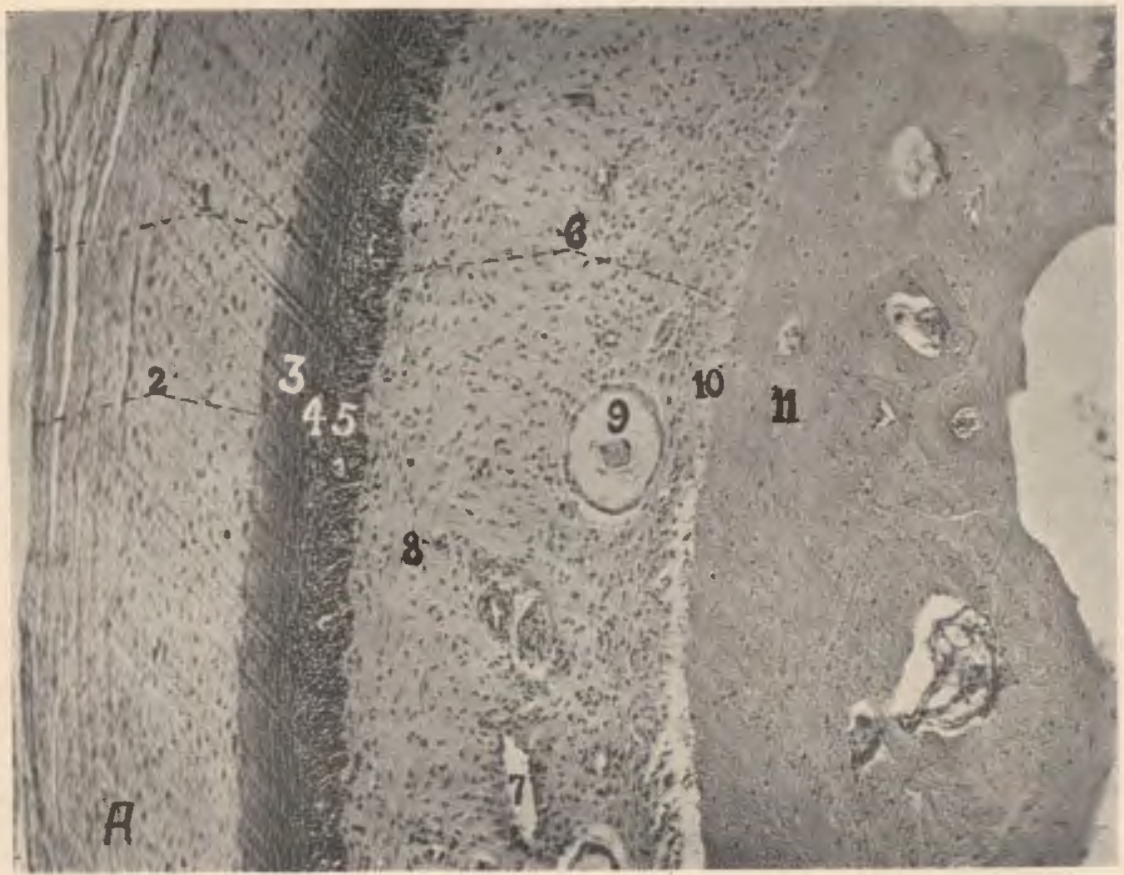

Plate IV - Fig. A. Upper beak, cross section. Hematoxylin-eosin. 200 X. 45 days.

1. Epidermis

2. Stratum corneum

3. Stratum lucidum

4. Stratum granulosum

5. Stratum germinativum

6. Corium
7. Blood ressels
8. Nerve
9. Taste corpuscle
10. Periosteum
11. Bone

blood vessels (7), nerves (8), and special nerve endings (9), as shown in Plate IV, Figure A.

The epidermis (Pl. IV, Fig. A-1) comprised four layers. The stratum germinativum (PI. IV, Fig. A-5) was composed of three rows of tall cylindrical epithelial cells which changed abruptly to the stratum granulosum. (Pl. IV, Fig. A-4). This latter contained four to five layers of flattened cells, with their long axes parallel to the surface. They were distinctly granular. Intercellular bridges were very prominent in this layer. The stratum lucidum (Pl. IV, Fig. A-3) was less distinct than the corresponding layer in the skin of mammals. It comprised about one-eighth of the entire epidermis. The stratum corneum (Pl. IV, Fig. A-2) was a very thick layer of flat structureless cells. 


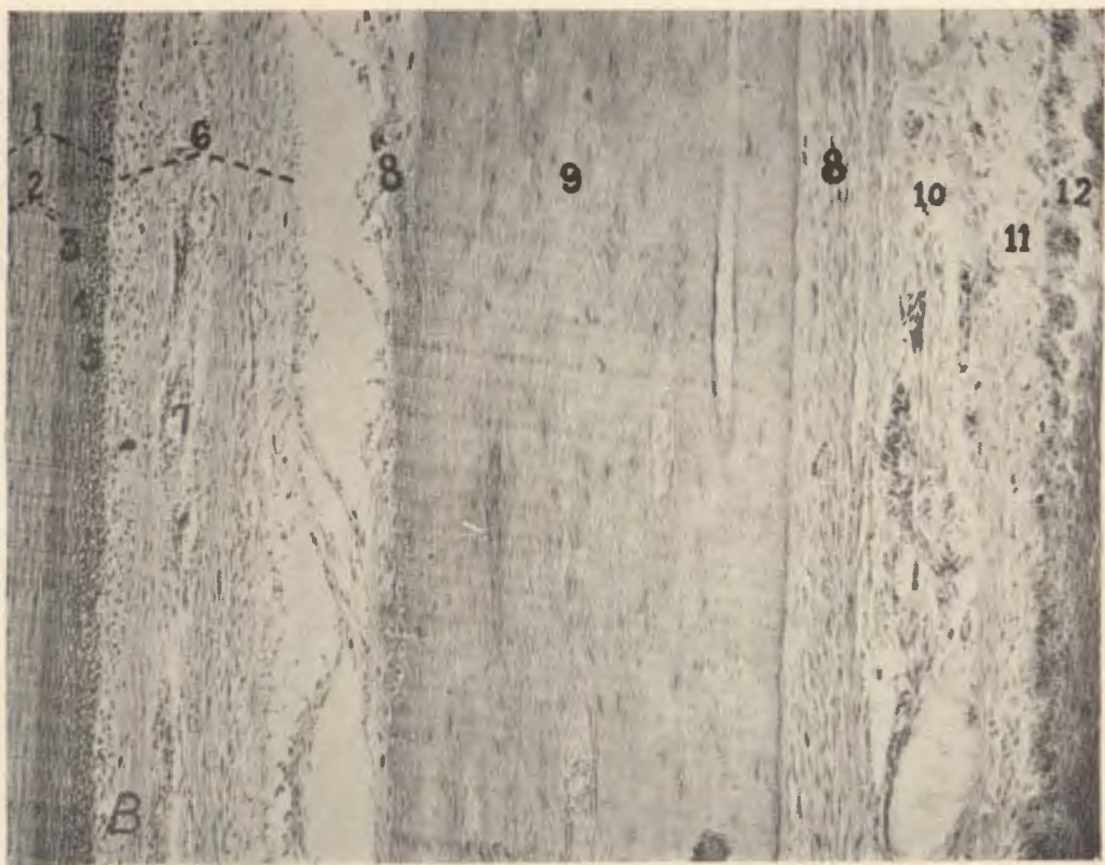

Plate IV - Fig. B. Lower beak, longitudinal section. Hematoxylin-eosin. $200 \times .45$ days.
1. Epidermis
2. Stratum corneum
3. Stratum lucidum
4. Stratum granulosum
5. Stratum germinativum
6. Corium
7. Blood vessels
8. Periosteum
9. Bone
10. Submucosa
11. Tunica propria
12. Epithelium of mouth

The general structure of the lower beak (Pl. IV, Fig. B) corresponded to the above. The cutis appeared more vascular. There were no taste corpuscles present. The epidermis was about onethird as wide as that of the upper beak. The stratum germinativum contained polyhedral cells, instead of cylindrical cells as in the upper beak.

\section{Mouth Cavity}

The mucous coat of the mouth cavity was lined throughout with stratified squamous epithelium. Papillae from the tunica propria extended into its basal layers, and projections from the epithelium protruded down between these papillae from the tunica propria. In the roof of the mouth (Pls. V-VII) the nuclei 


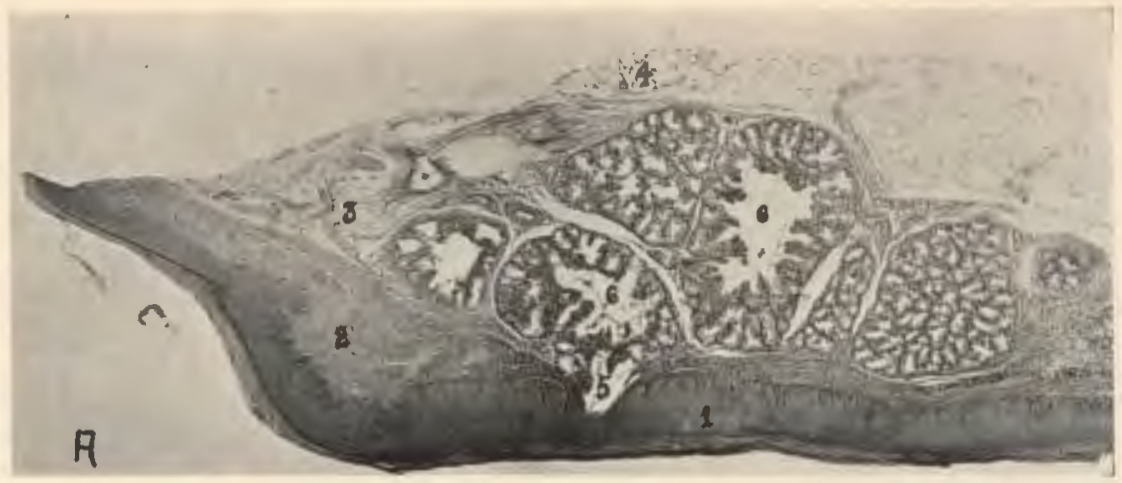

Plate V - Fig. A. Anterior portion of the hard palate.
1. Epithelium
4. Fat
2. Tunica propria
5. Exeretory duct
3. Submucosa
6. Maxillary salivary gland

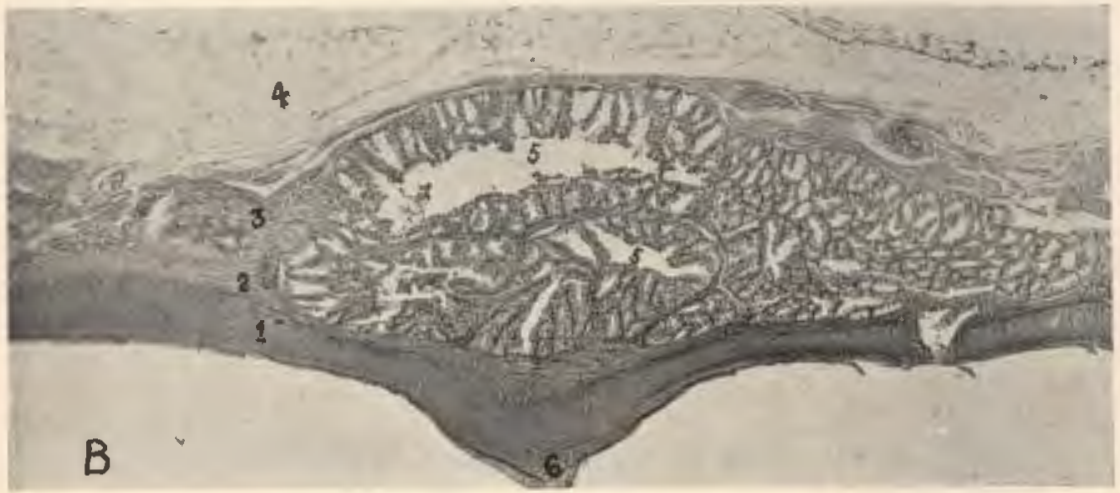

Fig. B. Mid-portion of the hard palate.
1. Epithelium
4. Fat
2. Tunica propria
3. Submucosa
5. Medial palatine salivary gland
6. Papilla of hard palate

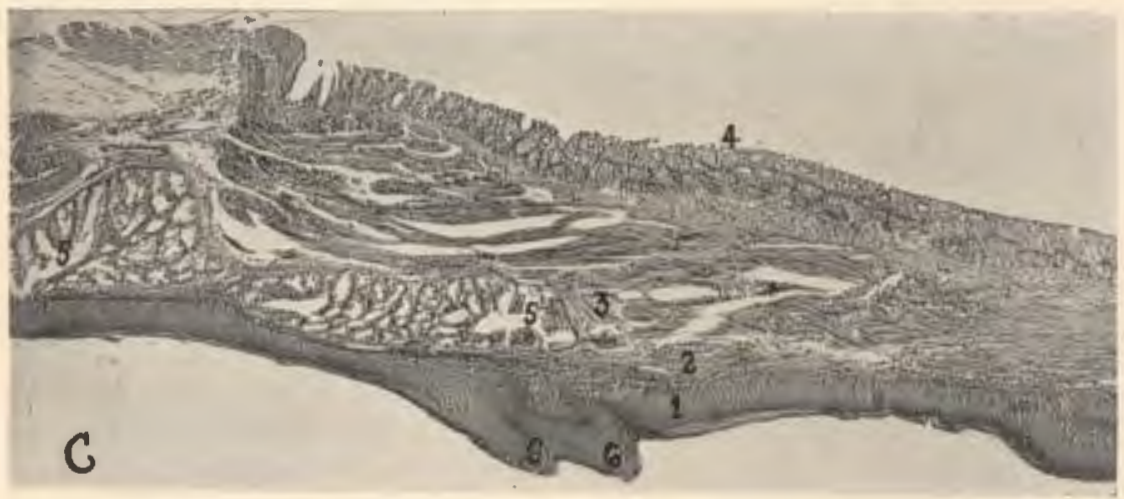

Fig. C. Region adjacent to the nares.
1. Epithelium
4. Nasal mucous membrane
2. Tunica propria
3. Submucosa
5. Medial palatine salivary gland
6. Papilla on hard palate 
of the cells of the outer surface of the epithelium were flatter than those of the basal layer and took a deeper stain. In places they appeared to be in a small cavity which did not take any stain.

The division between the tunica propria (Pl. V, Fig. A-2) and the submucosa ( $\mathrm{Pl}$. V, Fig. A-3) was rather an arbitrary one since there was no muscularis mucosae present until the posterior part of the pharynx was reached. (Pl. VII, Fig. A-3). The tunica propria contained many macroscopic papillae (Pl. VI, Fig. A-3 and Fig. B-6) which extended posteriorly. The microscopic papillae extending into the epithelium seemed shorter near the lateral borders. Elastic and white fibrous connective tissue was present in the tunica propria. Diffuse lymphoid tissue was observed in the tunica propria of the $11 / 2$-year-old specimen and a lymph nodule in the 2-year-old specimen. These were not evident in young chickens.

The submucosa (P1. V, Fig. A-3) was considered as that portion deeply to the tunica propria in which salivary glands lie. Since one gland was practically in continuity with another and these glands were paired, there were few areas in which no glandular tissue was present.

The submucosa contained elastic and white fibrous tissue, the latter forming a capsule about the glands. A fatty cushion was observed beneath the gland layers in many specimens (Pl. V, Fig. A-4). The muscular layer outside the submucosa was voluntary.

The floor of the mouth was very similar in structure to the roof of the mouth. Toward the lateral sides of the floor of the mouth the epithelium became less compact, the outer cells were more polyhedral, and the nuclei more spherical and pycnotic. The microscopic papillae of the tunica propria were more prominent.

\section{Tongue}

The general structure of the tongue (P1. VIII, Figs. A and B and Pl. IX, Fig. A) was similar in its entire length. A thick stratified squamous epithelium (Pl. VIII, Fig. B-l) covered the dorsal surface. In some instances the surface was uneven, the projections resembling low blunt papillae.

Plates V-VII represent a longitudinal section through the roof of the mouth and rynx. The figures are a series from a section extending from the beak to the esophs. Hematoxylin-eosin. $50 \times .2$ weeks. 


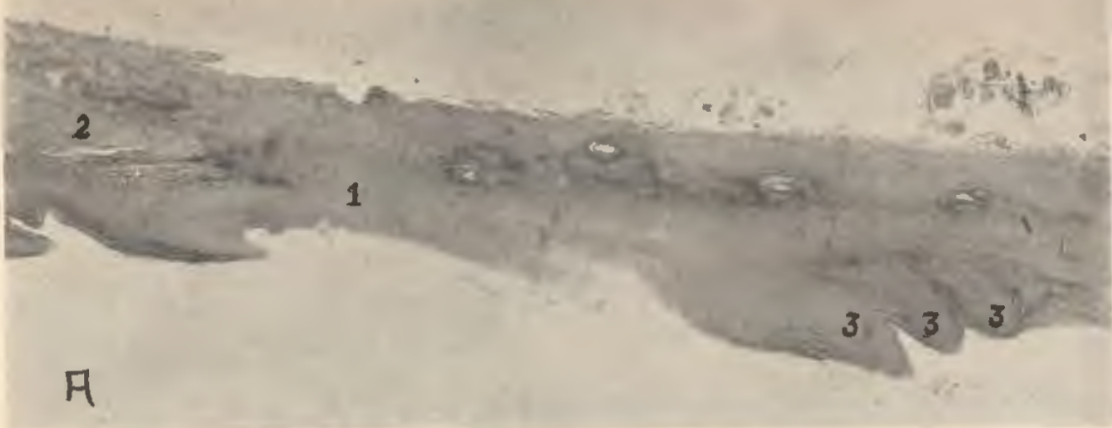

Plate VI-Fig. A. A longitudinal section through the mucosa lining the nares.

1. Epithelium

2. Tunica propria

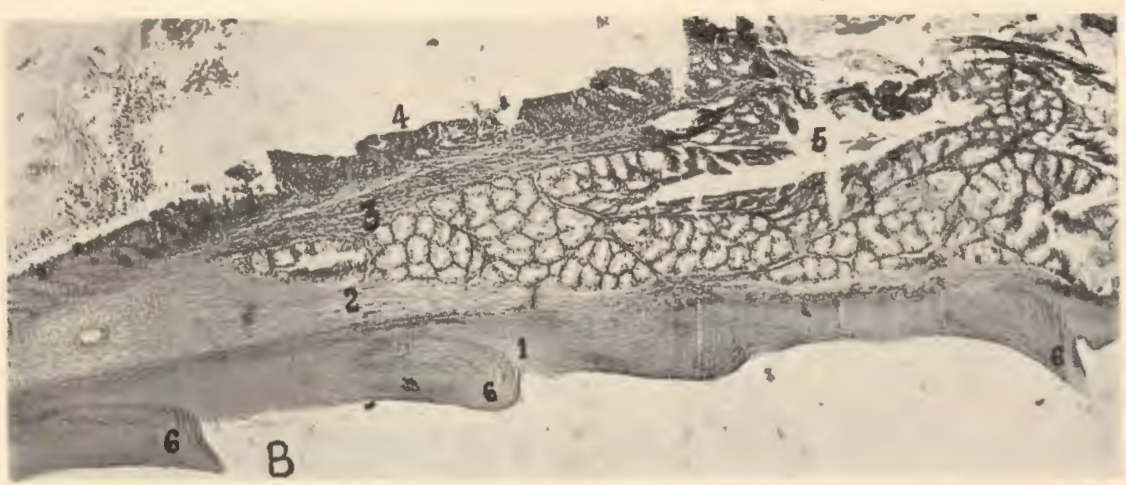

3. Papillae separating the roof of the mouth from the pharynx
Fig. B. Anterior portion of the pharynx.
1. Epithelium
2. Tunica propria
3. Submucosa

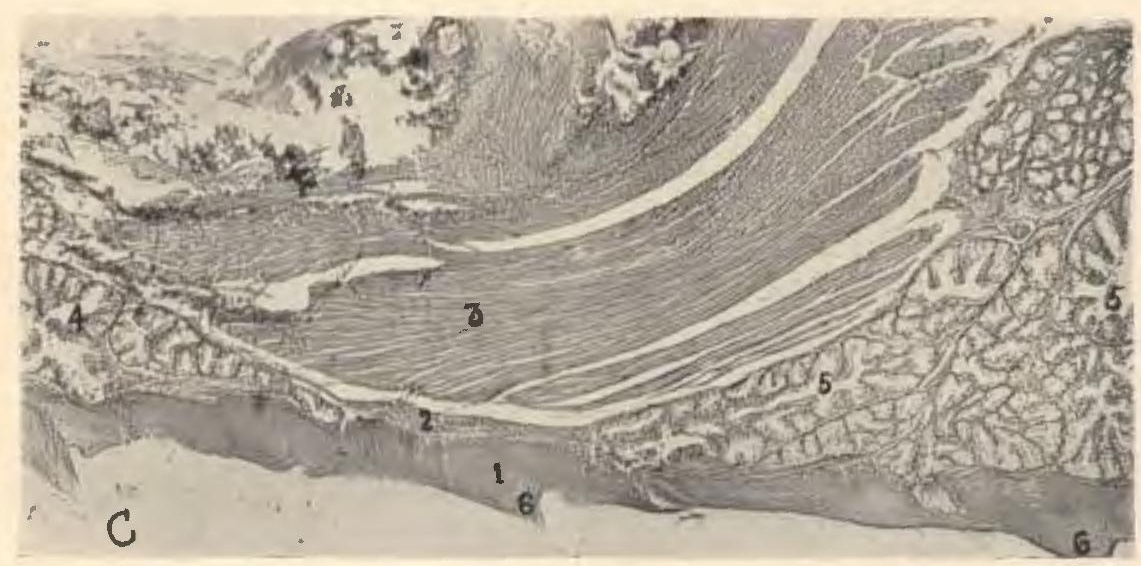

Fig. C. Mid-portion of the pharynx.

1. Epithelium

2. Tunica propria

3. Muscle arranged obliqualy to the roof of the pharynx
4. Epithelium of nasal cavity

5. Medial palatine gland

6. Papillae of the roof of the pharynx 


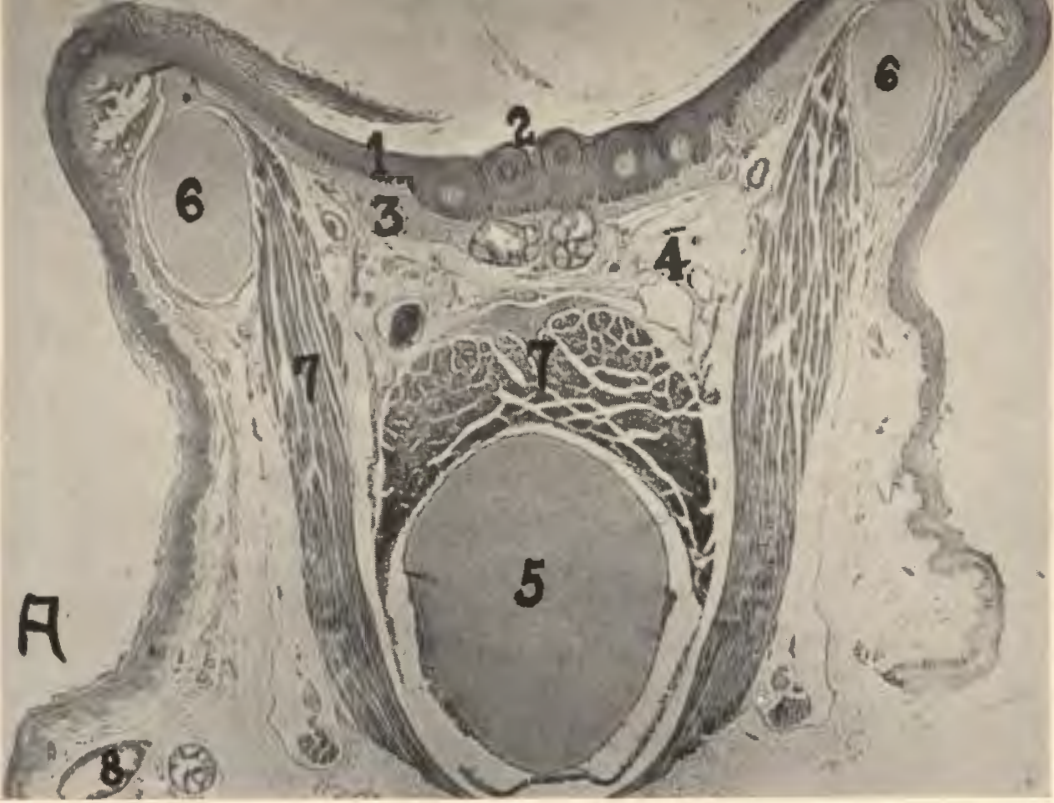

Plate IX - Fig. A. Base of tongue. Hematoxylin-eosin. $25 \times$. Baby chick.
1. Epithelium
5. Cartilage (basihyal bone)
2. Papillae
3. Tunica propria
6. Cartilage (entoglossal bone)
4. Submucosa
7. Muscle
8. Lingual glands

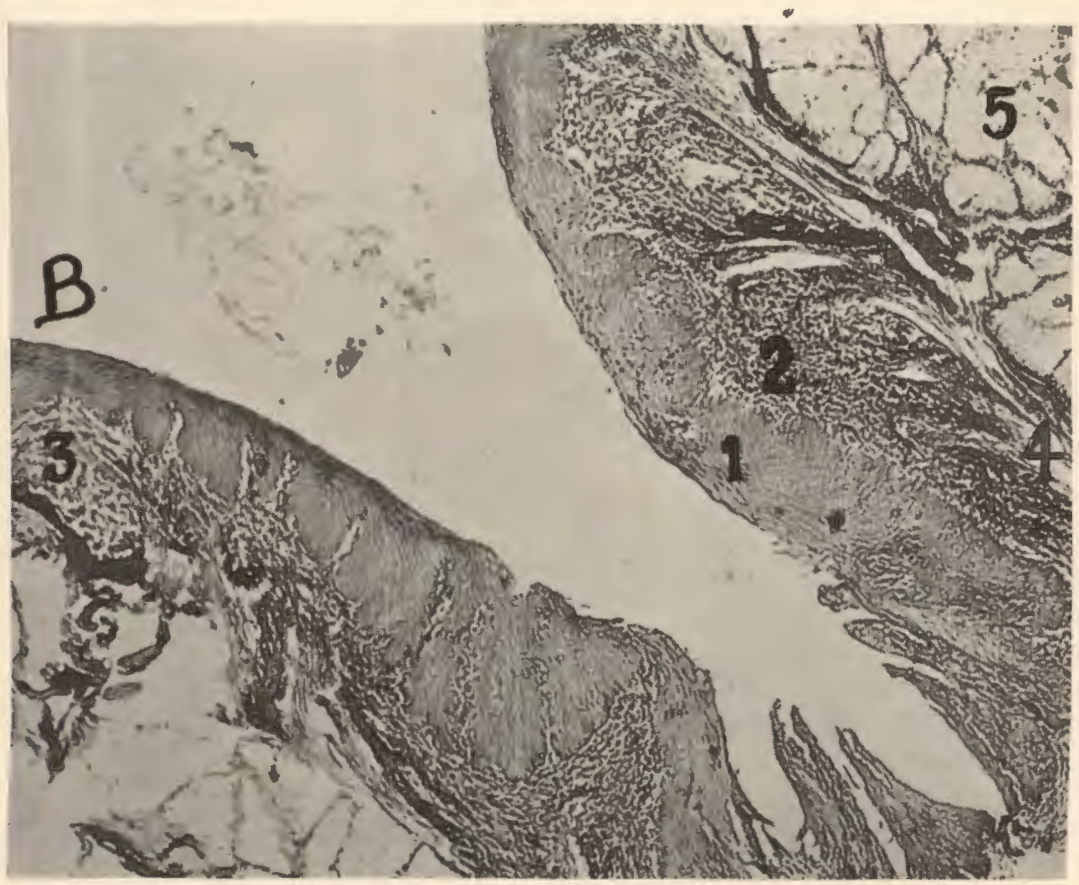

Fig. B. Cross section of Aditus laryngis. Hematoxylin-eosin. $50 \times .11 \frac{2}{2}$ years.
1. Epithelium
4. Submucosa
2. Lymphoid tissue in tunica propria
5. Cricoarytenoid gland 
The tunica propria (Pl. VIII, Fig. B-2) comprised the second layer, which contained the anterior lingual salivary glands on either side, (Pl. VIII, Fig. B-3), the entoglossal bone, (Pl. VIII, Fig. B-4) (cartilaginous in young birds) in the middle, with voluntary muscle (Pl. VIII, Fig. B-5) below the bone. The tunica propria was made up of white fibrous and areolar tissue containing blood and lymph vessels and nerves. Prominent microscopic papillae of tunica propria extended into the epithelium. In old birds the lower surface contained diffuse lymphoid tissue and an occasional lymphoid nodule. No lymphoid tissue was present in the tongue of a young specimen. The stratified squamous epithelium of the ventral surface of the tongue (Pl. VIII, Fig. B-6) was smooth. It was about one-third to one-fourth as thick as that of the dorsal surface. Toward the point of the tongue (PI. VIII, Fig. A) the lower epithelium became cornified and took a stain similar to the stratum corneum of the beak. Toward the base of the tongue the entoglossal bone (Pl. IX, Fig. A-6) presented a different picture than in the midportion. Two wings of this bone extended laterocaudally just below the dorsal surface of the tongue. In the center the basihyal bone was observed. (Pl. IX, Fig. A-5).

The muscles presented different pictures at different levels. Near the tip the muscle was practically absent. (PI. VIII, Fig. A) . A cross section from the mid-portion of the tongue is shown in Plate VIII, Figure B, and a section from near the base is shown in Plate IX, Figure A.

Serial sections of the tongue failed to reveal any taste buds.

\section{Salivary Glands}

Schauder's (1923) description and terminology was used for the location and naming of the salivary glands. A translation of the outline, including only the parts pertaining to the chicken, follows:

a) Glands at the bottom of the oral cavity.

1. Anterior submaxillary: largely developed, paired glands in the angle between the lower rami of the maxilla.

2. Posterior submaxillary in group of 3 :

$a$. anterior lateral, lying medial to the os dentale; $b$. intermediare, caudoventral to $a$; $c$. back mediale, postero-medial to and connecting with the intermediary group. 
b) Glands of angle of the mouth.

3. Angularis oris gland [Cholodkowsky (1892)]: lying in the angles of the beak, a small, three-cornered gland area.

c) Glands of the tongue.

4. Anterior lingual; at the side of, in the middle of, and in the posterior part of the tongue.

5. Posterior lingual: on the dorsal surface of the base of the tongue.

d) Glands of the roof of the mouth.

6. Paired glands joining medially in the hard palate lying before the posterior nares [maxillary of Heidrich, (1905) ].

7. Medial and lateral palatine glands: extending longitudinally to the posterior nares.

8. Sphenopterygoid: in the roof of the pharynx.

e) Glands of the pharyngeal canal.

9. Cricoarytaenoideae: lying lateral to the larynx in the submucosa of the cutaneous mucous membrane.

The salivary glands all presented the same structure. They consisted of branched tubular glands with openings into a common cavity (Pl. X, Fig. A-3) from which an excretory duct (Pl. X, Fig. A-1) led to the mouth cavity. The angularis oris and the maxillary glands had a single opening for each gland. Others had many openings for a single gland. The cells were columnar in shape with small nuclei which lay close to their bases. Fine septa containing white fibrous and elastic fibers, capillaries, and some muscle fibers extended between the tubules from the capsule which surrounded the acini. Basket cells were not definitely identified. There were some large cells in the septa, but their nature was not determined. The glands were entirely composed of mucous cells, and in no case were serous cells observed.

The buccal epithelium extended into the duct a short distance and then changed to a low columnar type which continued into and lined the collecting cavity, becoming taller again in the latter.

Lymphoid tissue (Pl. XI, Fig. A-4 and Pl. XII, Fig. B-6) was found between the lobules of all glands of the adult specimens except in the anterior lingual. Only the third group of the posterior submaxillary and the cricoarytenoid contained lymphoid tissue in the 5-month-old specimen, and of the two younger specimens the only indication of lymphoid tissue was in the cricoarytenoid of the 36-hour chick.

A peculiar structure was observed in some of the glands. The cell outlines had disappeared, and the result was one conglomerate mass of secretion and cellular debris (Pl. XI, Fig. A-5). A similar area in another section (Pl. XI, Fig. B-2) took a mucous stain. 


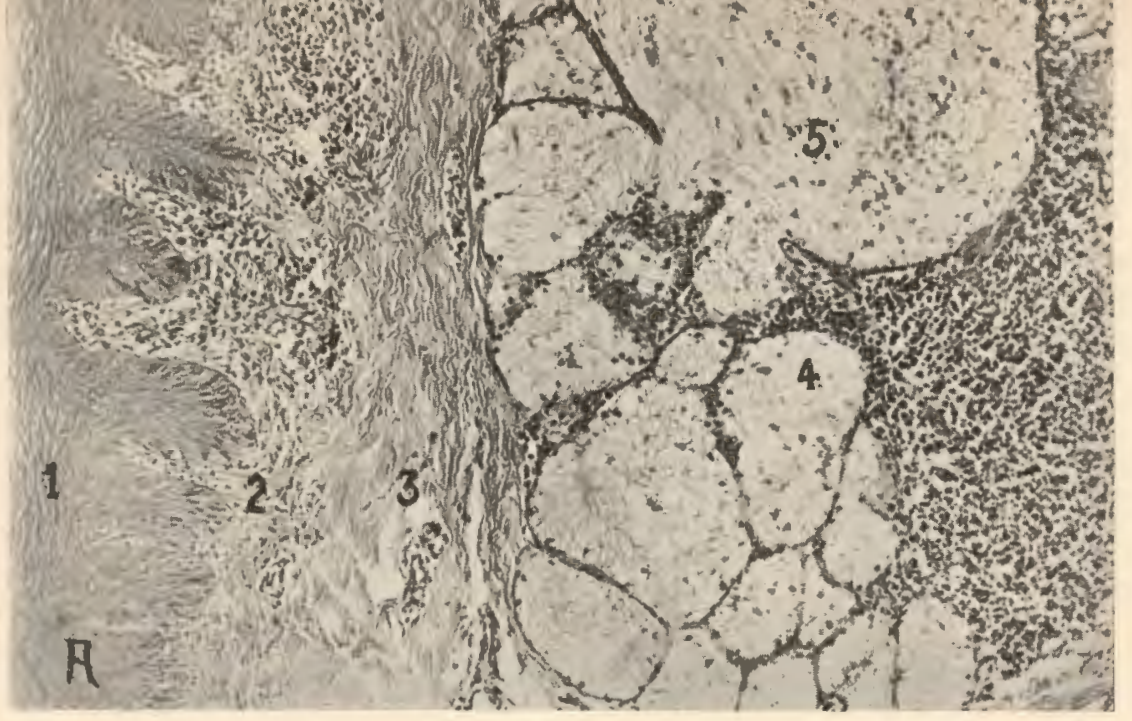

Plate XI-Fig. A. Sphenopterygoid salivary gland with lymphoid tissue. Hematoxylineosin, $200 \times .2$ years.

1. Epithelium of pharynx

2. Tunica propria

3. Submucosa

4. Gland showing infiltration with lymphoid tissue
5. Glandular orea with cell outlines absent

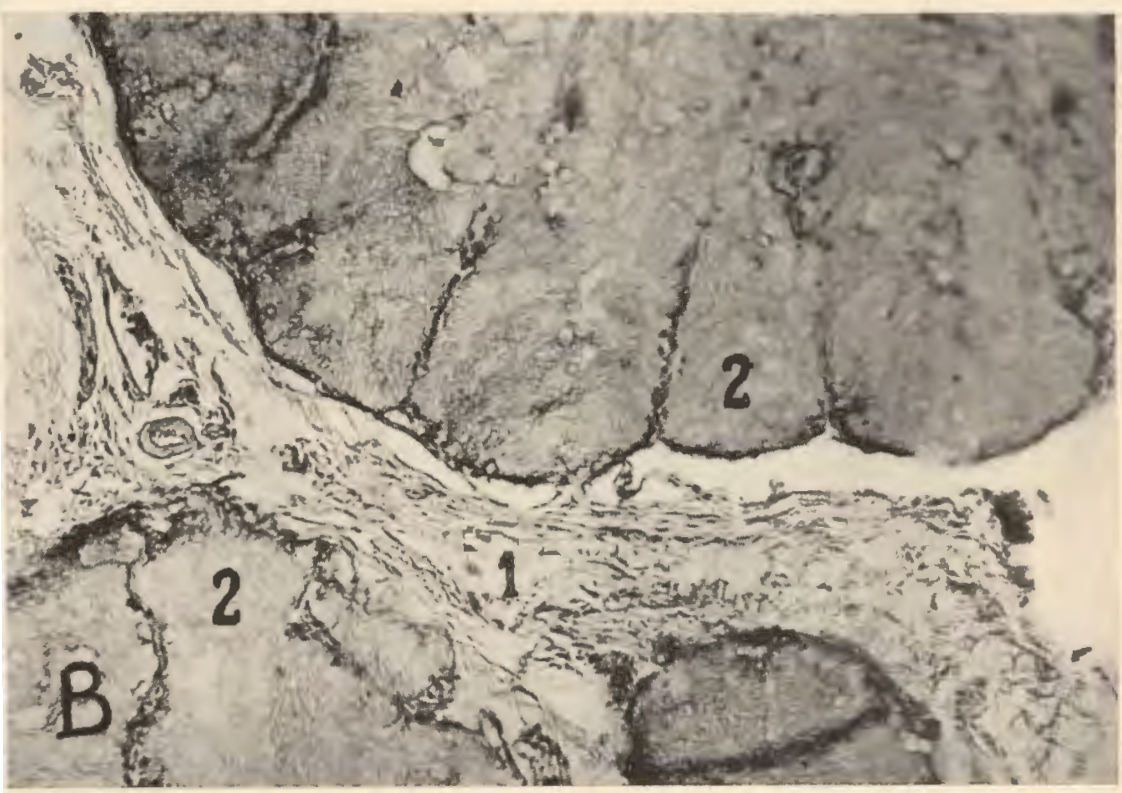

Fig. B. Posterior submaxillary salivary gland stained for mucin. $200 \times .5$ months.

1. Submucoso

2. Posterior submaxillary salivary gland 


\section{Pharynx}

The pharynx extended from the row of papillae at the back of the hard palate (Pl. VI, Fig. A-3) to the row of papillae at the entrance of the esophagus. (Pl. VII, Fig. A-8). The roof of the pharynx was composed chiefly of the medial palatine (Pl. VI, Fig. C-4) and the sphenopterygoid glands (Pl. VI, Fig. C-5) between which lay a voluntary muscle making an oblique angle with the epithelium (Pl. VI, Fig. C-3). The microscopic structure resembled that of the mouth as did that of the floor of the pharynx. The latter contained the posterior lingual and the cricoarytenoid glands in its wall.

The structure regarded by some authors as a tonsil was observed as a lymphoid infiltration of the tunica propria in the region of the aditus laryngis (Pl. IX, Fig. B). Some lymph nodules were present under the stratified squamous epithelium.

As in the tongue, a study of serial sections of the pharynx did not reveal any taste corpuscles. If they are present in the domestic chicken, this author has not been able to locate them.

The wall of the digestive tube proper consisted essentially of a mucous membrane, comprised of an epithelial lining, tunica propria, and muscularis mucosae; a submucosa; a lamina muscularis; and an adventitia or serosa depending on the location of the organ.

\section{Esophagus}

The esophagus was similar in structure both anterior and posterior to the crop. It was characterized by a wide stratified squamous epithelial layer (Pl. XIII, Fig. A-1). The basal layer of the epithelium projected between prominent papillae of the tunica propria. The epithelium showed a loosening of the outer layers with a tendency to slough off. In the tunica propria (P1. XIII, Fig. B-2) were contained large mucous glands (Pl. XIII, Fig. B-3). The tunica propria was made up of a network of fibrous tissue which contained many blood vessels, lymph vessels, and nerves. As the bird advanced in age the elastic tissue became more dense in the submucosa, (Pl. XIV, Fig. B) and was observed in the tunica propria. Lymphoid nodules were also observed. The mucous glands were lined by low cuboidal epithelium which decreased in height as it approached the surface, finally becoming flattened (Pl. XV, Fig. B-3). 


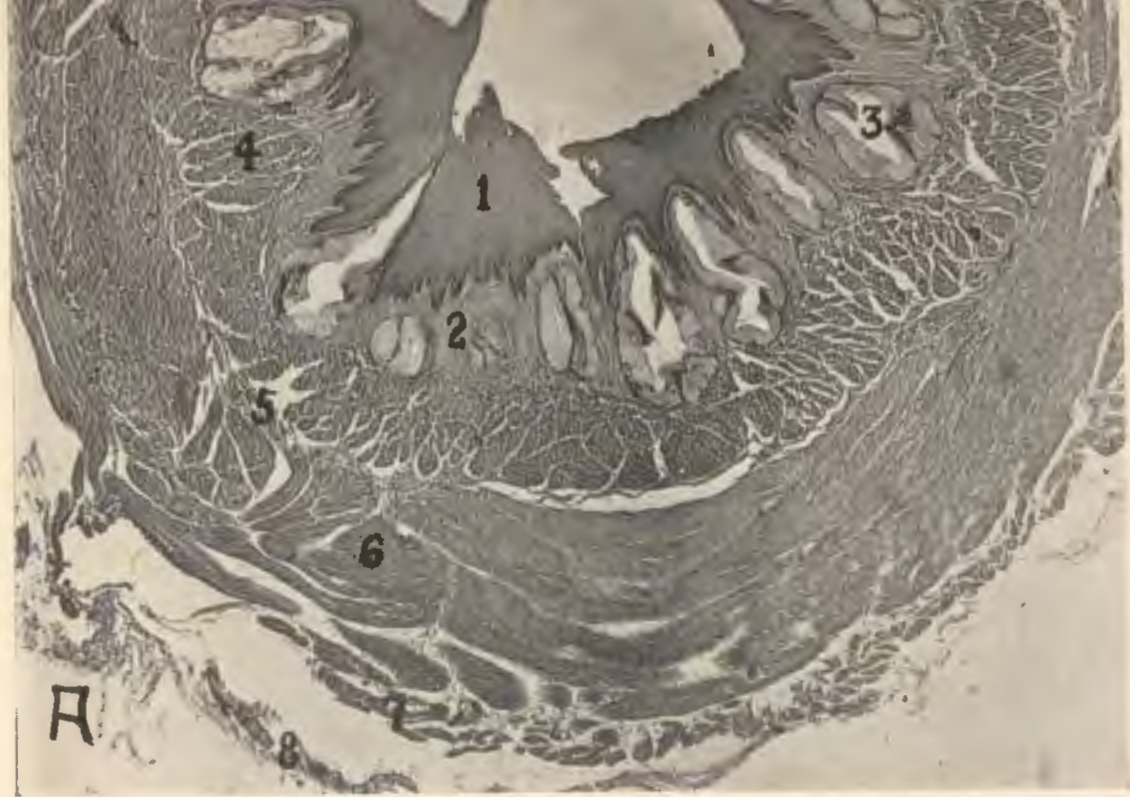

Plate XIII - Fig. A. Esophagus (near crop) cross section. Hematoxylin-eosin. $50 \times .20$ days.

1. Epithelium

2. Tunica propria

3. Mucous glands

4. Muscularis mucosae

5. Submucosa
6. Inner circular layer of the lamina muscularis

7. Outer longitudinal layer of the lamina muscularis

8. Adventitio

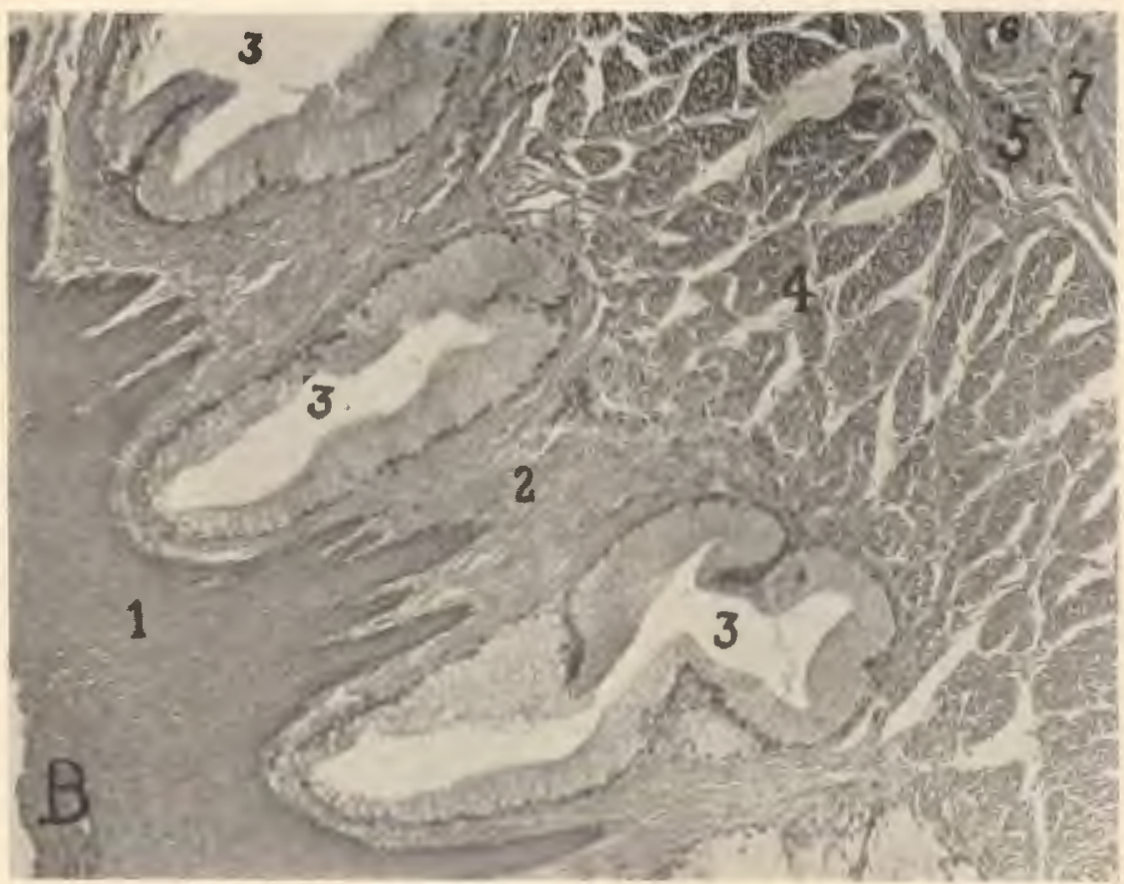

Fig. B. Esophagus (same as above). Hematoxylin-eosin. $200 \times .30$ days.
1. Epithelium
2. Tunica propria
5. Submucosa
3. Mucous glands
6. Blood ressel
4. Muscularis mucosae
7. Circular layer of lamina muscularis 


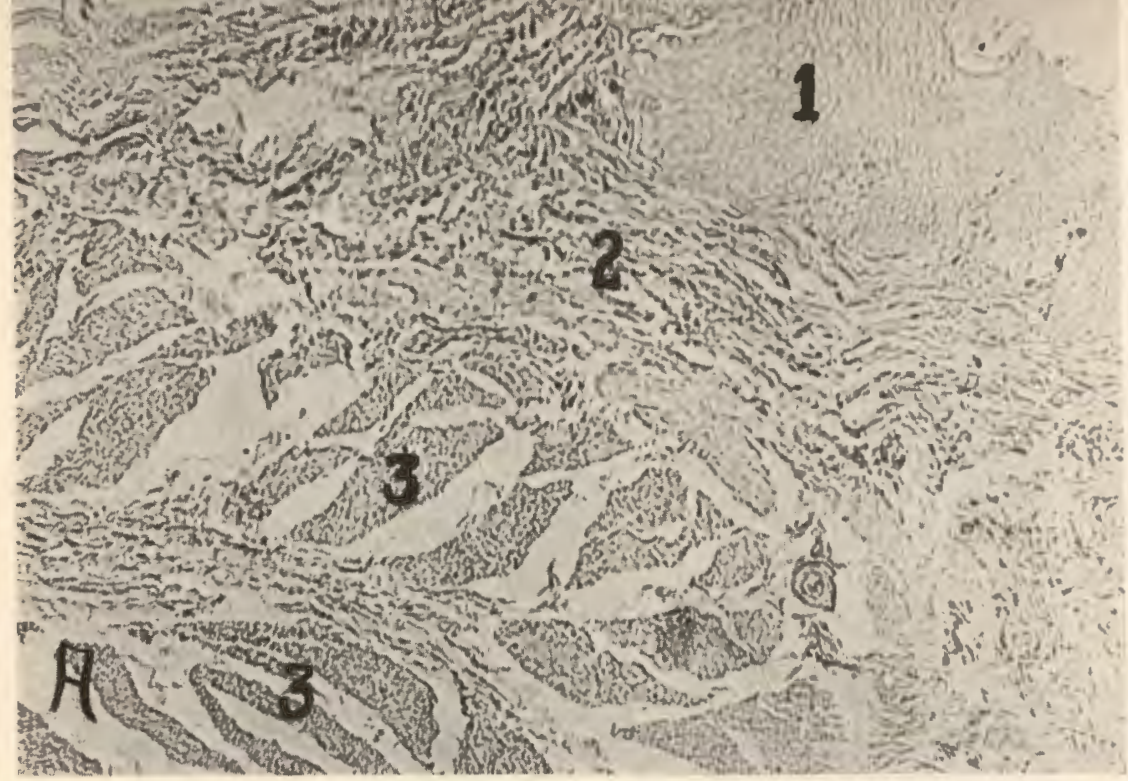

Plate XV - Fig. A. Esophagus showing leucocytic infiltration of the glands. Mid-portion, cross section. Hematoxylin-eosin. $50 \times$. 11/2 years.

1. Epithelium

2. Tunica propria

3. Muscularis mucosae

4. Mucous gland with lymphoid tissue
5. Submucosa

6. Circular muscle layer of lamina muscularis

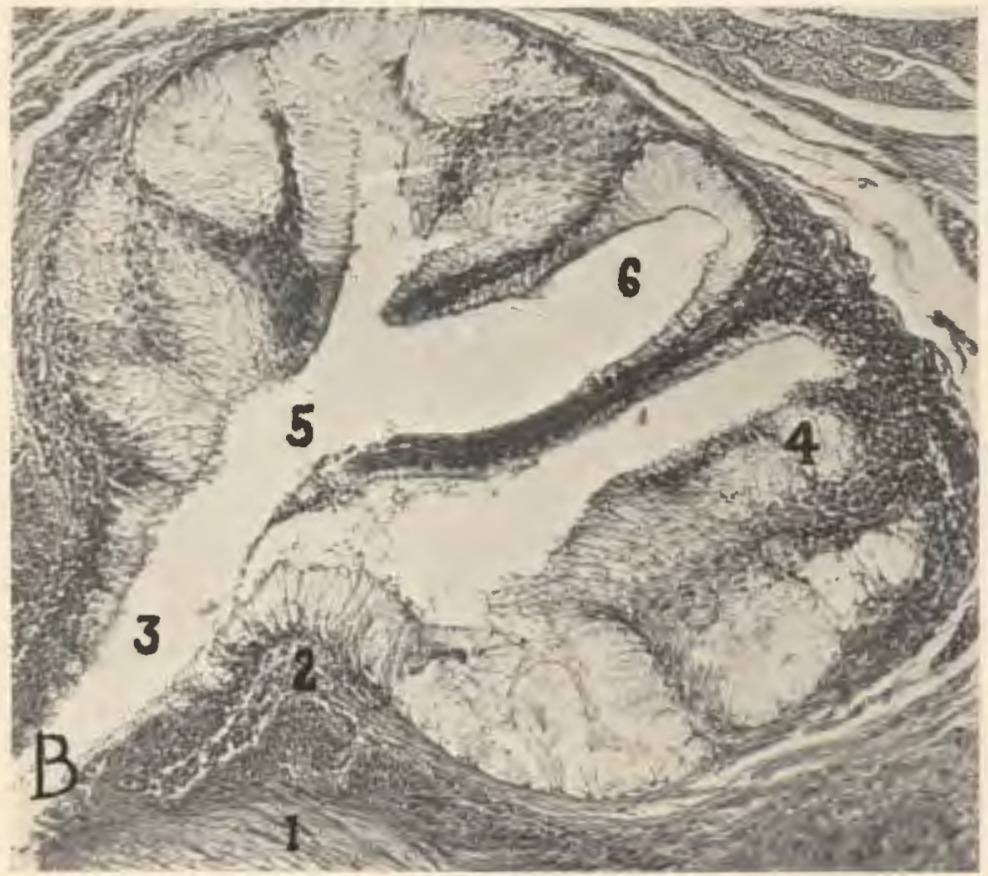

Fig. B. Mucous gland opening into lumen of esophagus. Hematoxylin-eosin, $200 \times 11 / 2$ years.

1. Epithelium

2. Tunica propria

3. Excretory duct
4. Gland with Iymphoid tissue

5. Collecting cavity

6. Gland fubules 
The muscularis mucosae (P1. XIII, Fig. A-4) was of thick involuntary muscle arranged longitudinally. It was about three times as thick as the outer longitudinal layer of the lamina muscularis.

The submucosa (Pl. XIII, Fig. A-5) was thin, hardly discernible in places, while in others it widened out and a few blood vessels and nerves could be distinguished in it.

The lamina muscularis (PI. XIII, Fig. A-6 and 7) consisted of a thick inner circular layer and a thin outer longitudinal layer of involuntary muscle. In specimens from birds aged 5 months, $11 / 2$ years, and 2 years, a heavy elastic tissue layer was in close contact with the outer longitudinal muscle layer.

The outer layer or adventitia (Pl. XIII, Fig. A-8) was thin, and served to unite the esophagus to adjacent structures. It contained elastic and white fibrous tissue and many plexuses of blood and lymph vessels and also nerves.

\section{Crop}

The lesser curvature of the crop (Pl. XVI, Fig. B) had essentially the same structure as the esophagus of which it was a part. The structure of the diverticulum of the crop (Pl. XVI, Fig. A) differed in some respects from the esophagus with which its walls were continuous. The glands of the crop (P1. XVI, Fig. B-3) were confined to an area which was close to the junction with the esophagus. The epithelial projections between the papillae of the tunica propria were more rounded. The same sloughing of the epithelium was observed here. None of the specimens showed any lymphoid tissue in the diverticulum of the crop, but it was present in the esophageal wall of the crops of older birds. In three specimens the muscularis mucosae appeared to be arranged in an outer longitudinal and an inner circular layer (Pl. XVI, Fig. A-3). In the other two birds it was difficult to make out any circular layer. Elastic tissue was observed exteriorly to the outer longitudinal muscle layer of this organ in the baby chick, and it increased with age, spreading to the other layers of the wall. Many blood vessels were present in the adventitia, between the muscle bundles, and in the submucosa.

\section{Junction of Proventriculus and Esophagus}

The epithelium of the esophagus became narrower as it approached the proventriculus and changed at the junction into the 


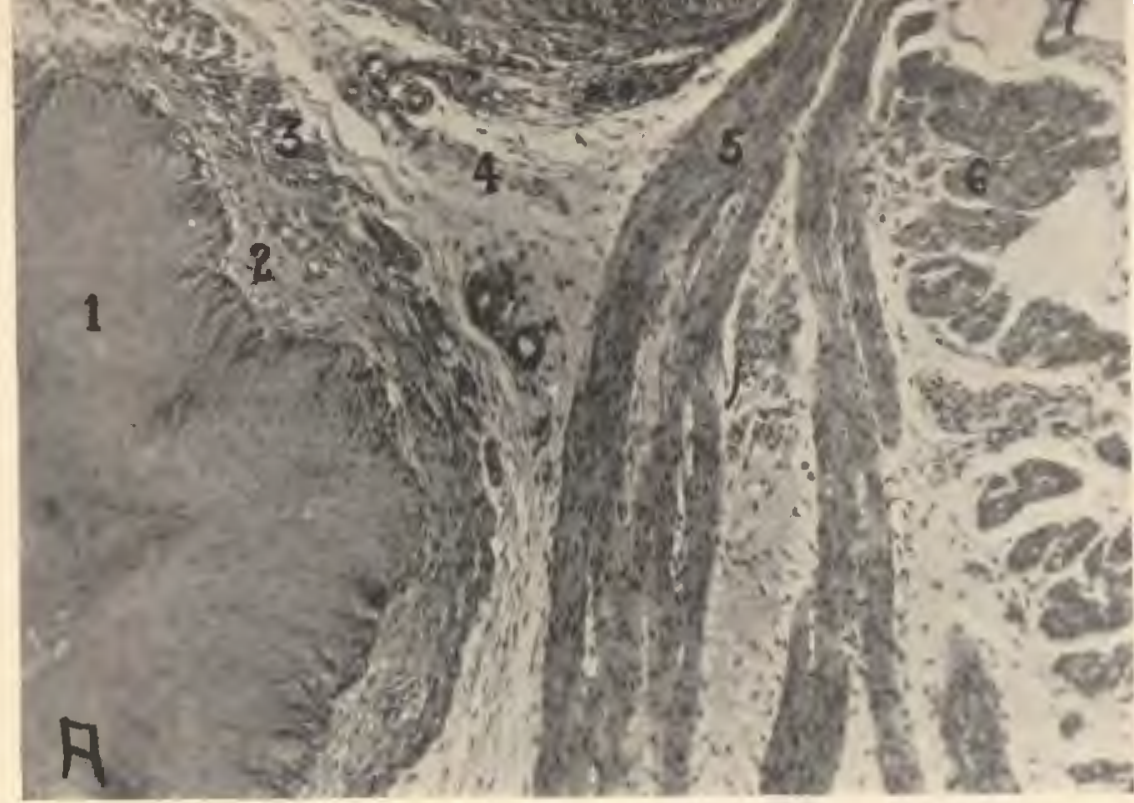

Plate XVI - Fig. A. Crop (diverticulum), cross section. Hematoxylin-eosin. $200 \times .36$ hours.

1. Epithelium

2. Tunica propria

3. Muscularis mucosae

4. Submucosa
5. Circular layer of the lamina muscu. laris

6. Longitudinal layer of the lamina muscularis

7. Adventitia

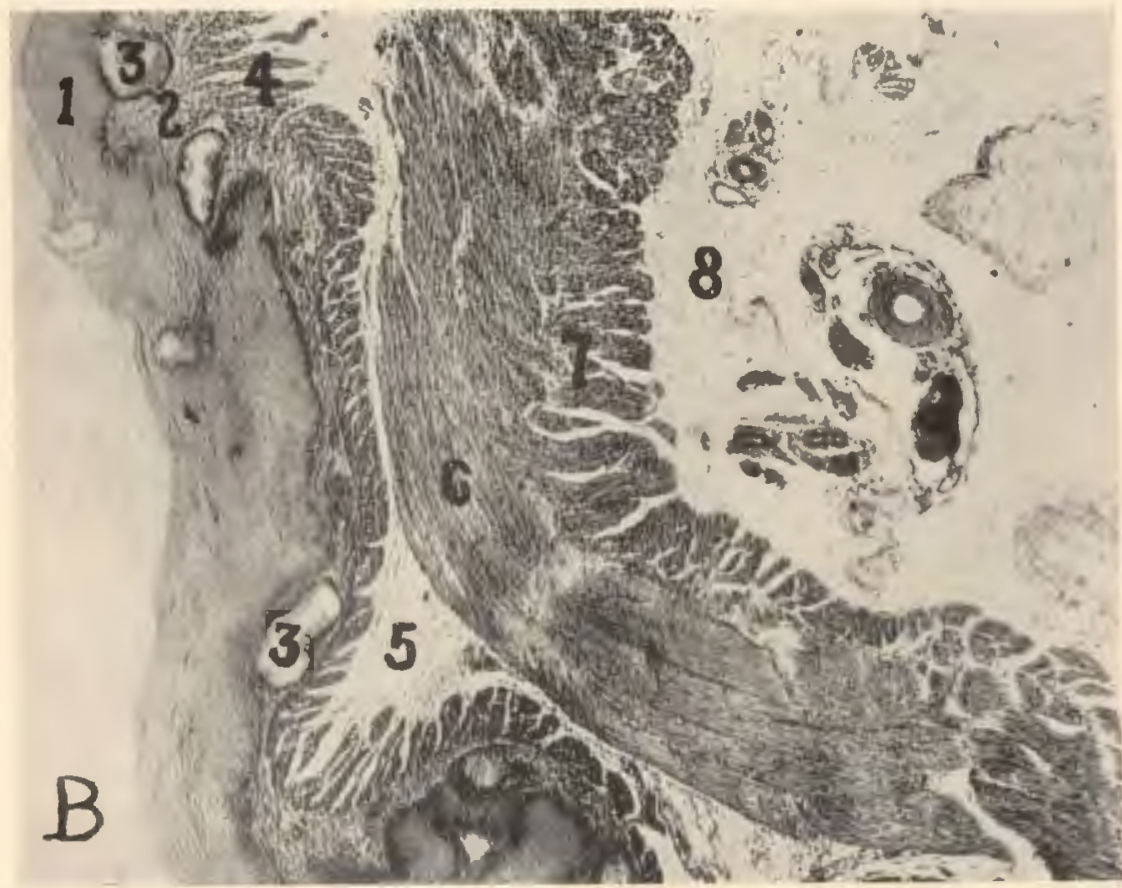

Fig. B. Crop (esophageal wall), eross sectian. Hemataxylin-eosin. $50 \times 20$ days.

1. Epithelium

2. Tunica propria

3. Mucous glands

4. Muscularis mucosae

5. Submucosa

6. Circular layer of the lamina muscularis

7. Longitudinal layer of the lamina muscularis

8. Adventitia (with many blood vessels) 
one-layered simple columnar epithelium found in the remainder of the digestive tract except in the anus.

There was no abrupt change from one type of gland to the other. The mucous glands of the esophagus were found in the inner layer of the tunica propria, while in the deeper layer the anterior extremity of the glands of the proventriculus was observed.

Lymphoid tissue was found in the tunica propria of a section taken from a 3-day-old bird.

\section{Proventriculus}

The mucosal surface of the proventriculus presented several macroscopic papillae, each of which contained an opening from the proventricular glands (Pl. XVII) .

The organ was lined by simple columnar epithelium covering plicae and lining sulci which were arranged concentrically around the gland openings (Pl. XVII and XVIII). On a cross section of the organ this arrangement gave the often misinterpreted appearance of surface tubular glands (Pl. XIX, Fig. B). They were so described by this author in the original article (Calhoun, 1933) and by Foust (1952). Recent research by Sjögren (1945) on the development of the proventriculus and gizzard in birds also refers to surface tubular glands. Plate XVIII shows these concentric plicae in a cross section of a papilla. The tunica propria extended into the plicae or laminae as shown in the same plate.

The muscularis mucosae (Pl. XIX, Fig. B-4) was observed below the surface glands, in the septa between the deeper glands, and in a longitudinal layer almost in contact with the lamina muscularis. The submucosa (Pl. XIX, Fig. A-8) was so thin as to appear absent in places. The lamina muscularis (Pl. XIX, Fig. A-9 and 10) showed the usual outer longitudinal and inner circular layers. The adventitia (Pl. XIX, Fig. A-11) appeared as a loose fascia containing few blood and lymph vessels and nerves.

Elastic tissue was demonstrable in the 36 -hour chick and increased in amount as the bird aged. It predominated in the tunica propria and the septa between the deep glands. Lymphoid tissue was observed in the tunica propria in the three oldest specimens.

The deeper glands of the proventriculus presented two different pictures. On cross section the gland tubules (Pl. XX, Fig. A-1) showed a meshwork, the strands of which had a serrated appearance. On longitudinal section the glands (Pl. XX, Fig. A-2) 


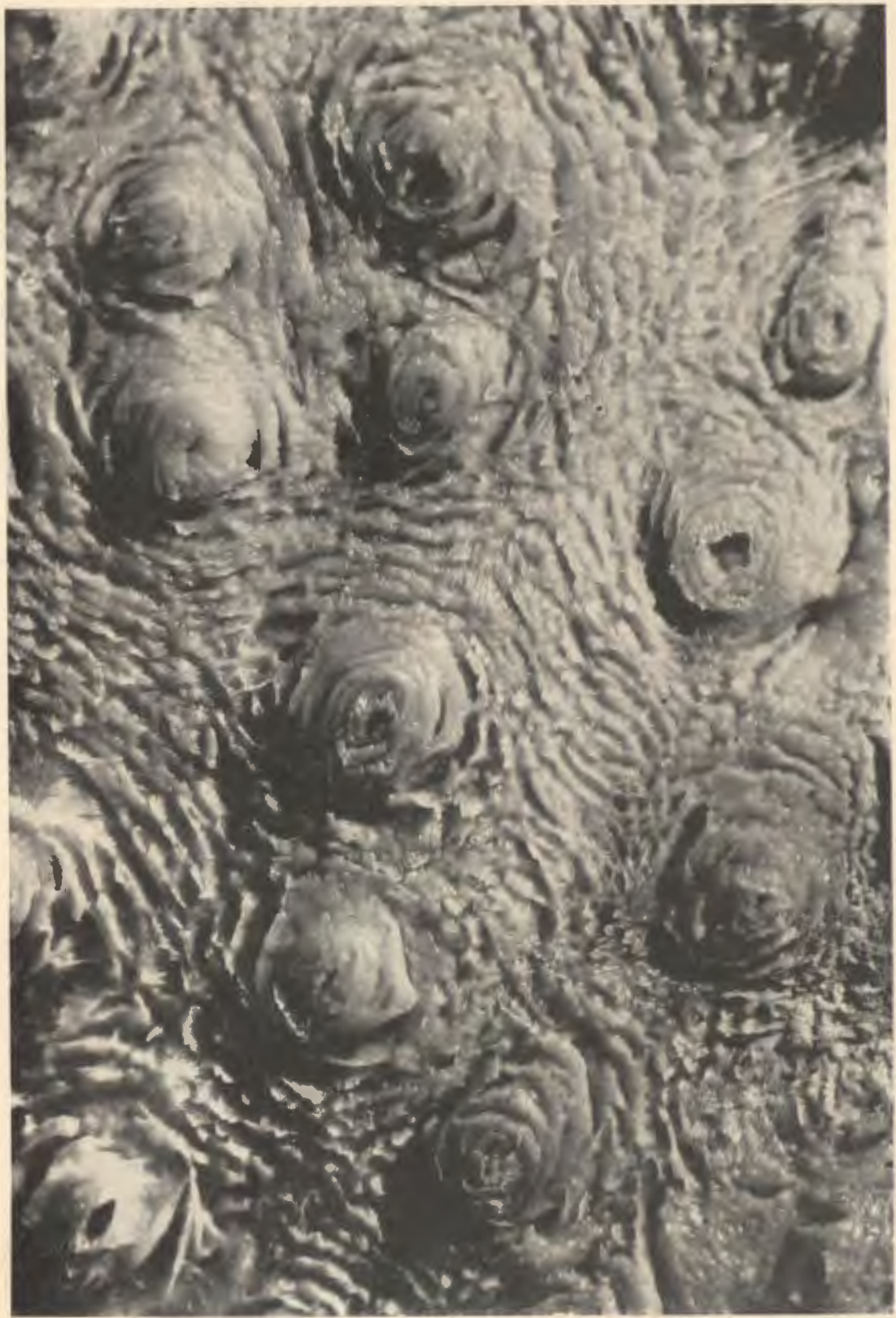

Plate XVII - Mucosal surface of the proventriculus of a 3-month-old chicken. Note the concentric arrangement of plicae around the openings from the glands and the irregular arrangement between the papillae. Gross. $10 \times$. 


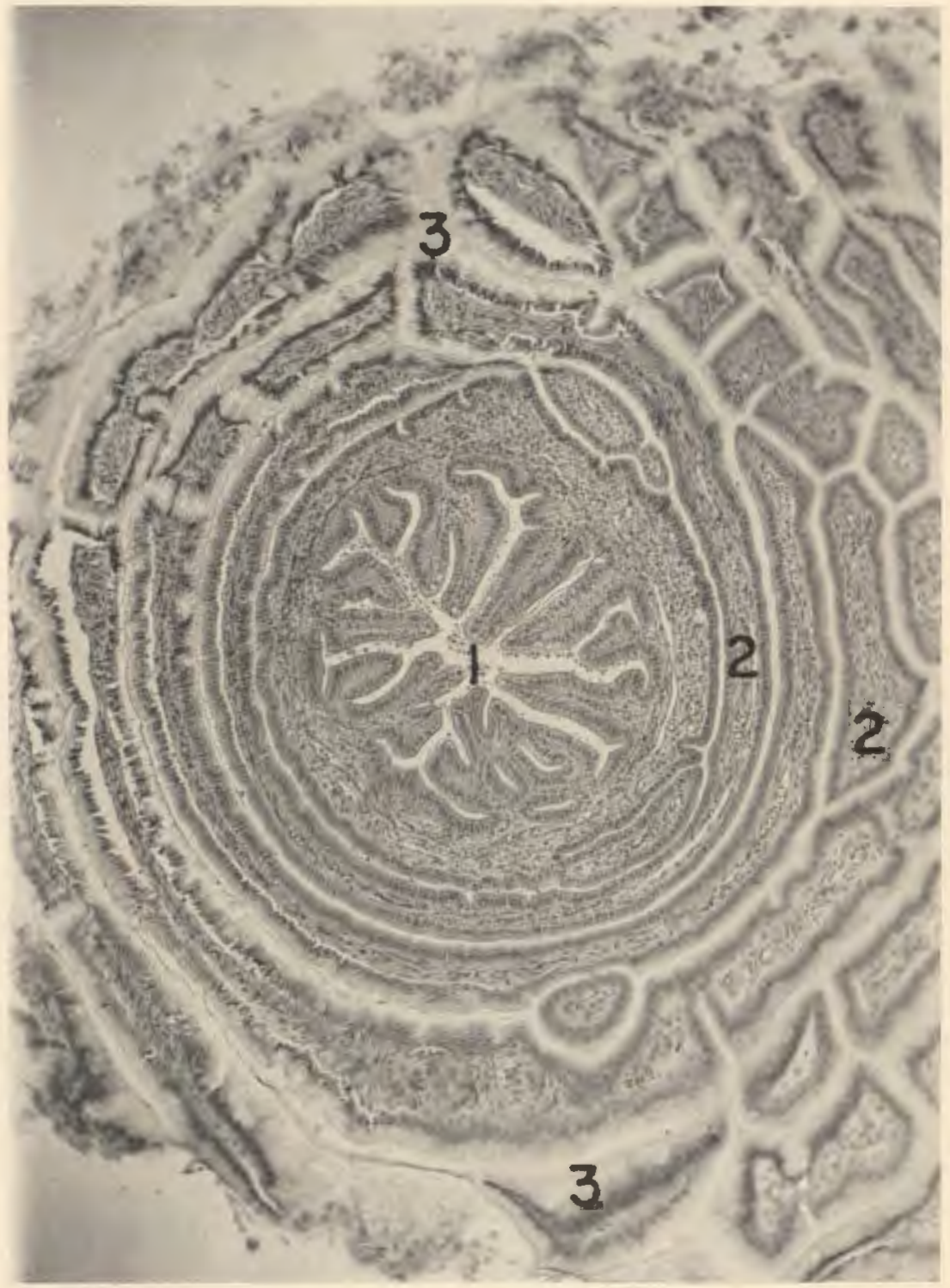

Plate XVIII - Cross section of a single proventricular papilla showing the arrangement of the concentric plicae about the opening from the proventricular glands. Hematoxylin-eosin. $10 \times .3$ months.

1. Gland opening

2. Tunica propria of plicas

3. Sulci 
showed long tubules, the cells (Pl. XX, Fig. A-4) of which were arranged obliquely to the axs of the tubule. The distal half or more of a single cell was not in contact with the neighboring cell thus giving the appearance of a serrated edge. A spherical nucleus was situated about the central part of the cell usually located toward the proximal half. The tubules opened into a central collecting cavity (PI. XIX, Fig. A-5), which was lined with columnar epithelium. These collecting cavities opened on the inner surface of the proventricules as mentioned above.

The septa (Pl. XX, Fig. A-3) surrounding the lobules contained white fibrous and yellow elastic connective tissue, some muscle fibers, blood and lymph vessels, and nerves. The surface epithelium, the epithelium of the collecting canals, and that of the excretory ducts of the deeper glands took a mucous stain in its distal third.

\section{Junction of Proventriculus and Gizzard}

The deep glands of the proventriculus ended abruptly, as did the plicae on the surface. The cells lining the sulci soon took on the characteristic aspect of the gizzard glands and a keratinized layer was observed above them.

The white fibrous connective tissue of the tunica propria joined with that from the submucosa and continued into the gizzard as the submucosa.

The layer of the muscularis mucosae above the deep glands of the tunica propria apparently tapered off at the point where the tunica propria and submucosa joined. The deep portion of the muscularis mucosae widened out and was continued into the gizzard with the circular muscle layer of the proventriculus. These two continued as separate layers for a short distance and then became fused into a single layer of fibers which became a part of the musculari intermedii of the gizzard.

The outer longitudinal layer of the lamina muscularis ceased at the junction of the proventriculus and the gizzard.

Elastic tissue was particularly dense in this region in the 2year-old specimen (PI. XX, Fig. B).

\section{Gizzard (Ventriculus)}

The gizzard had as its innermost lining a horny layer (Pl. XXI, Fig. A-1) which was about three-fourths as thick as the glandular layer adjacent to it. This horny layer was an exudate 


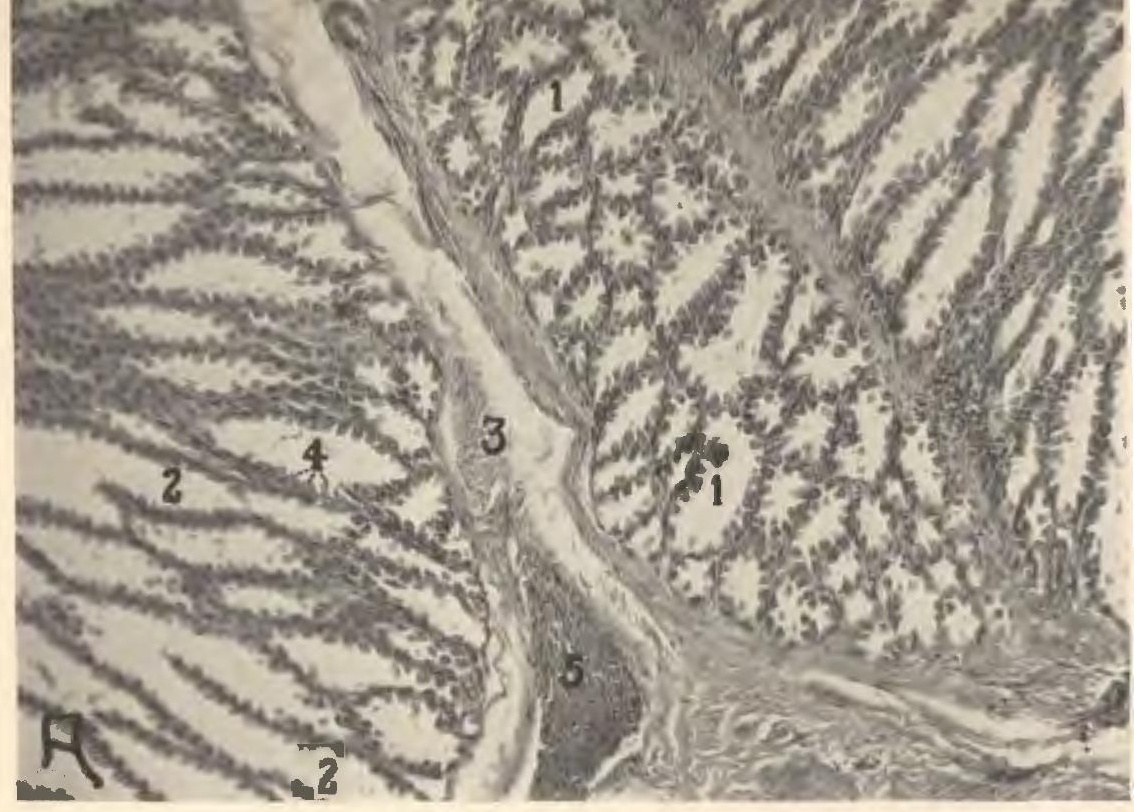

Plate XX - Fig. A. Proventriculus. Hematoxylin-eosin. $200 \times .36$ hours.

1. Cross sections of gland tubules

2. Longitudinal sections of gland tubules

3. Septa between lobules
4. Gland cells

5. A mass of blood cells in a blood vessel

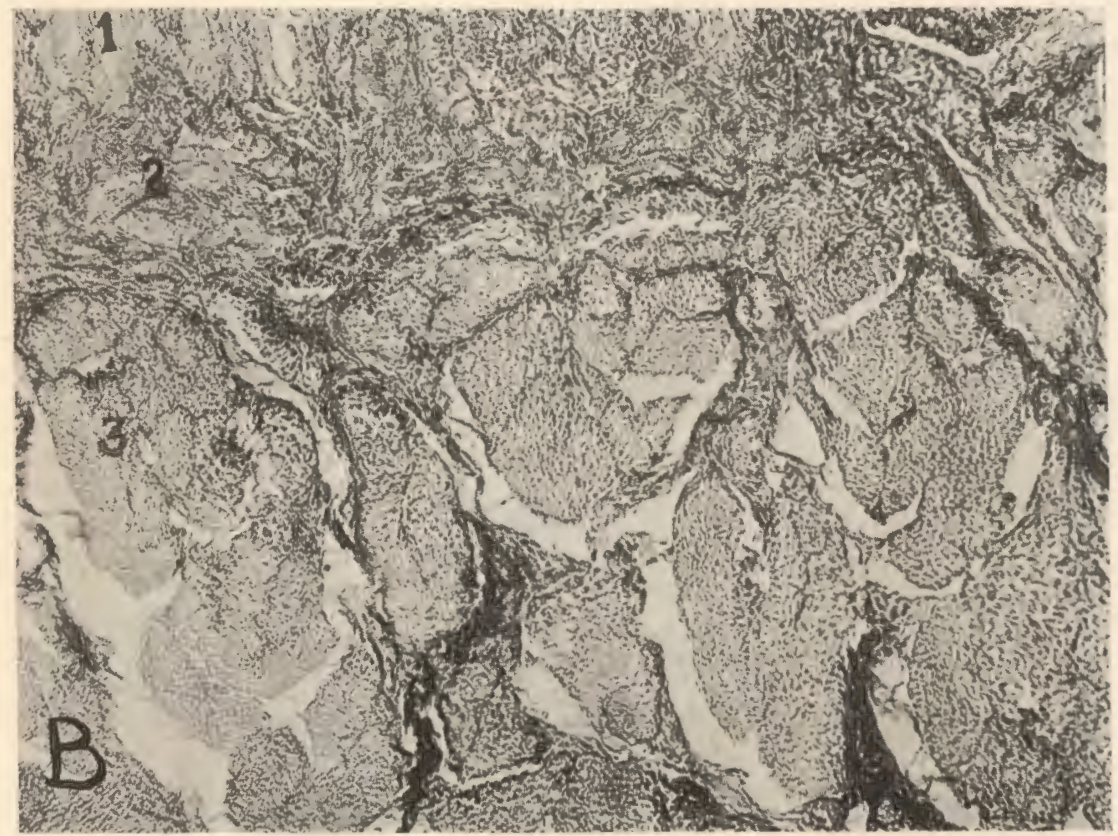

fig. B. Elastic tissue in orea between proventriculus and gizzard. (Elastic tissue black.) Weigert's. $200 \times .2$ years.

1. Gland layer

2. Tunica propria

3. Muscularis mucosae 
from the glands and contained wavy lines (Pl. XXI, Fig. B-2) parallel to the surface, and colonnades or thickenings (Pl. XXI, Fig. B-3) perpendicular to the surface. The former apparently were formed by consecutive layers of the exudate and the latter by secretion being poured out at the same point; also, cellular debris was observed in this horny layer.

The epithelium of the mucous membrane was simple columnar and contained crypts, at the bottom of which opened the branched tubular glands of this organ. (Pl. XXI, Fig. A-2) .

The glands of the gizzard were in the tunica propria and arranged in groups presenting in longitudinal section the arrangement shown in Plate XXII, Figure A-1. The gland tubules were lined with low cuboidal epithelium containing spherical nuclei which bulged into the lumen in places (Pl. XXII, Fig. B-3). The tubes were filled with an exudate which took a bright red stain with keratohyalin staining (P1. XXIII, Fig. B-1). The gland cells themselves contained small granules of keratohyalin (PI. XXIII, Fig. B-3). Elastic tissue was demonstrable in the tunica propria of the three oldest birds.

The muscularis mucosae was absent from the gizzard. The submucosa (Pl. XXI, Fig. A-3) was a dense layer of white fibrous and yellow elastic connective tissue, the former predominating. Blood vessels, lymphatics, and nerves were present.

The muscular mass (Pl. XXI, Fig. A-4) was comprised of a single thick layer of parallel fibers which extended from one aponeurosis to the other. It was criss-crossed by bands of white fibrous connective tissue which seemed to connect particularly to the fibrous submucosa (Pl. XXIV, Fig. B). At the junction of the smooth muscle and fibrous aponeurosis a white fibrocartilage was observed in many areas in specimens from several different ages (Pl. XXIV, Fig. A).

Near the center of the tendinous aponeurosis (P1. I-11) the submucosa came in contact with the tendinous tissue of the aponeurosis and the muscular tissue was absent.

Exterior to the muscle a thin layer of connective tissue (P1. XXI, Fig. A-5) containing nerves and blood and lymph vessels was present. Elastic tissue was present in this layer in all birds observed. Peritoneum covered the whole organ.

Lymphoid tissue was not observed in the gizzard wall in any of the five specimens originally studied nor in any of the six specimens observed for this revision. 


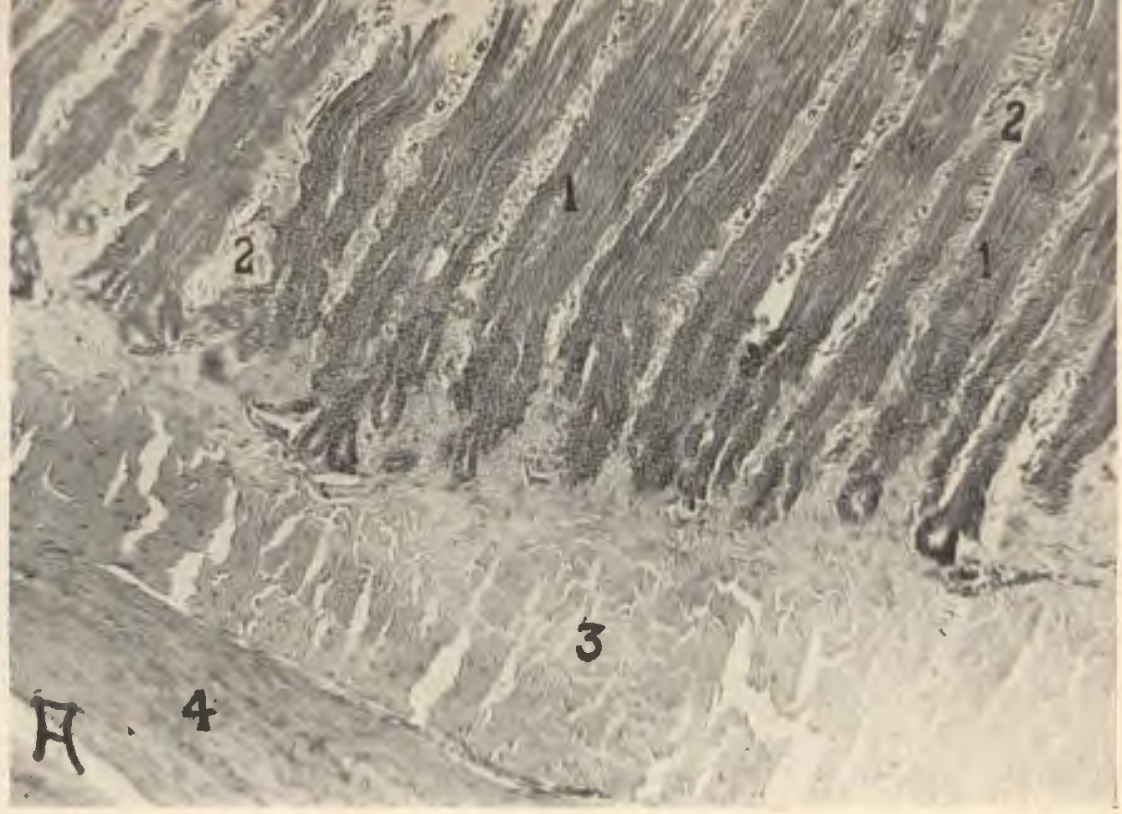

Plate XXII - Fig. A. Gizzard. Hematoxylin-eosin. $200 \times .2$ years.
1. Gland tubuies in funica prapria (note
3. Submucosa arrangements in groups)
4. Muscie

2. Septa of tunica propria

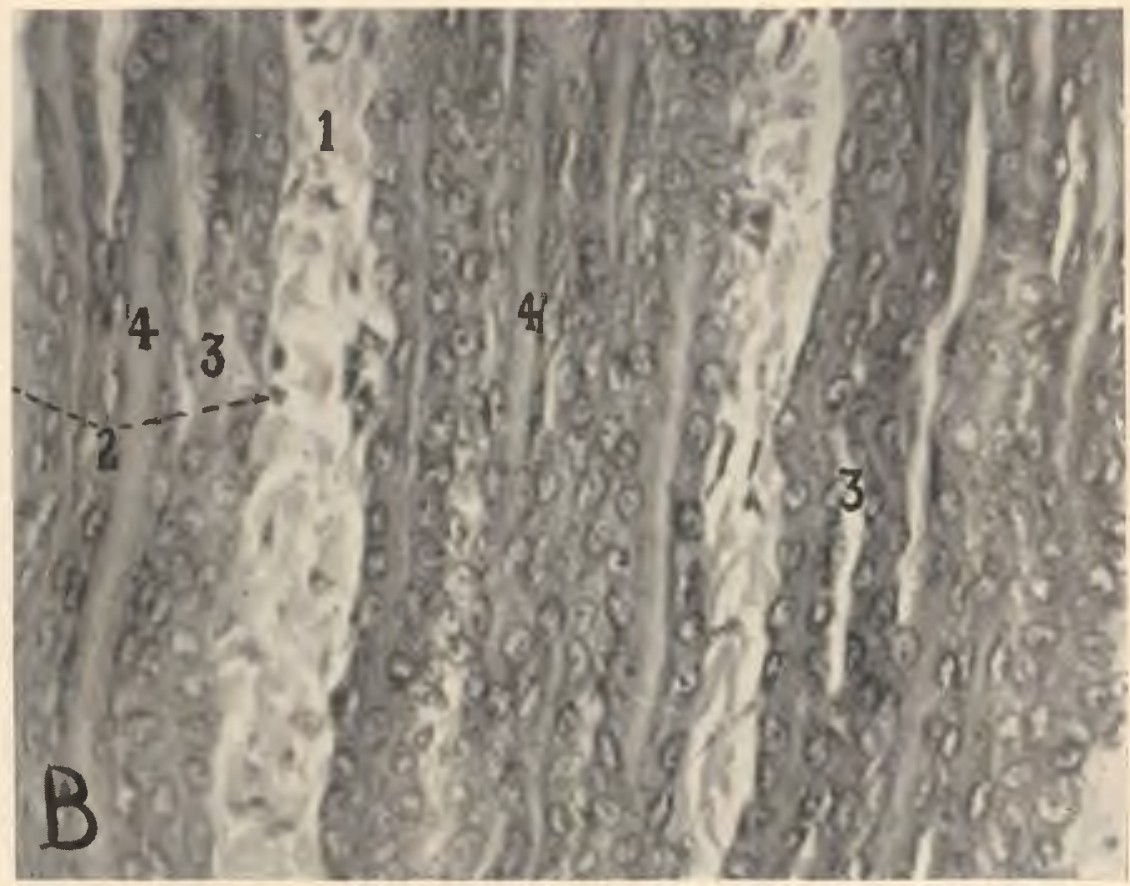

Fig. B. Gizzard. Hematoxylin-eosin, $800 \times .2$ years.
1. Tunica propria septa
3. Flat cells with bulging nuclei
2. Group of gland tubules
4. Lumen of a tubule 


\section{Section Between Gizzard and Duodenum}

In the region between the gizzard and the duodenum, the mucous membrane became narrow only to widen again after it made an acute angle. It again made a slight turn, and at this point the horny layer ceased. Just posterior to this there was a short section resembling the portion of the mammalian duodenum in which Brunner's glands are present. Lymphoid tissue was observed in the area between the gizzard and duodenum in specimens as young as three days old.

\section{Small Intestine}

The structure of the small intestine, duodenum included, was similar throughout. The inner layer of the mucous membrane was lined with simple columnar epithelium with many goblet cells. These were mucous both on the lumen and in the glands of Lieberkühn (Pl. XXV, Fig. B-4). The inner surface showed villi (PI. XXVI, Fig. A-10 and PI. XXVIII) between which the crypts of Lieberkühn (Pl. XXVI, Fig. A-8) opened. The villi contained lacteals, blood vessels, muscle fibers, and lymphoid tissue, the latter varying with the age of the chicken. In the 36 -hour chick there was much embryonic connective tissue in the tunica propria filling the villi and surrounding the glands of Lieberkïhn. Practically no lymphocytes were observed at this age, but by the twentieth day they were scattered throughout the tunica propria. The villi branched, sometimes twice (Pl. XXVII, Fig. A). Elastic tissue was observed in the tunica propria of the three oldest chickens (Pl. XXVIII, Fig. B-1).

The muscularis mucosae was comprised of an outer circular and an inner longitudinal layer (P1. XXVI, Fig. A-5). The latter sent fibers into the villi. In places the outer circular layer appeared to fuse with the circular layer of the lamina muscularis (Pl. XXVI, Fig. A-6) .

The submucosa was apparent only in a few places and then was only a very thin layer (PI. XXVI, Fig. A-4). There were a few blood and lymph vessels and nerves in addition to the connective tissue.

The lamina muscularis was made up of an inner circular and an outer longitudinal muscle layer with a connective tissue layer on each side, which contained plexuses of nerves, and blood and lymph vessels. (Pl. XXVI, Fig. A-2 and 3). 


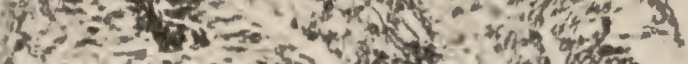

(1)

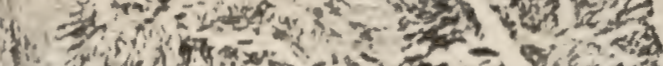

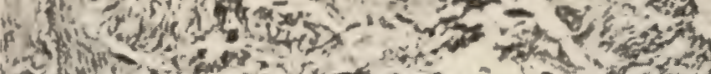

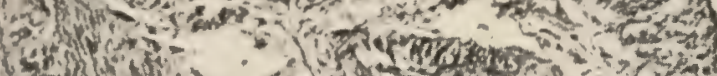

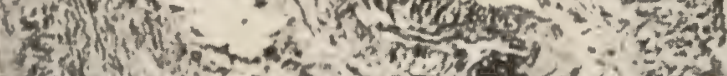

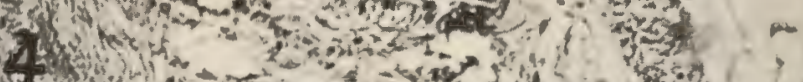

3 (1)

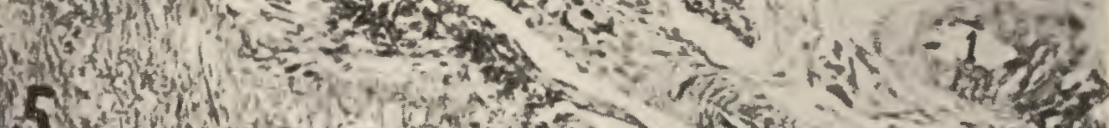

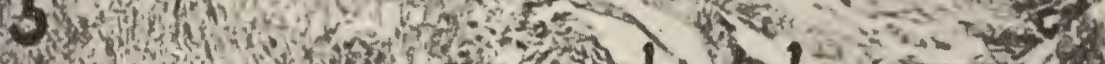

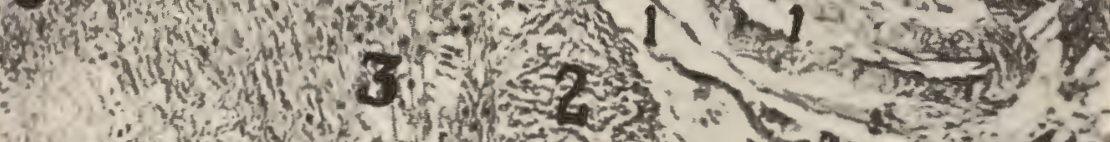
16)

Plote XXV - Fig. A. Small intestine showing blood vessels entering the wall. Hematoxylin-eosin. $200 \times .2$ years.

1. Vessels in adventitia

2. Longitudinal muscle layer

4. Submucosa

3. Circulor muscle loyer

5. Muscularis mucosae

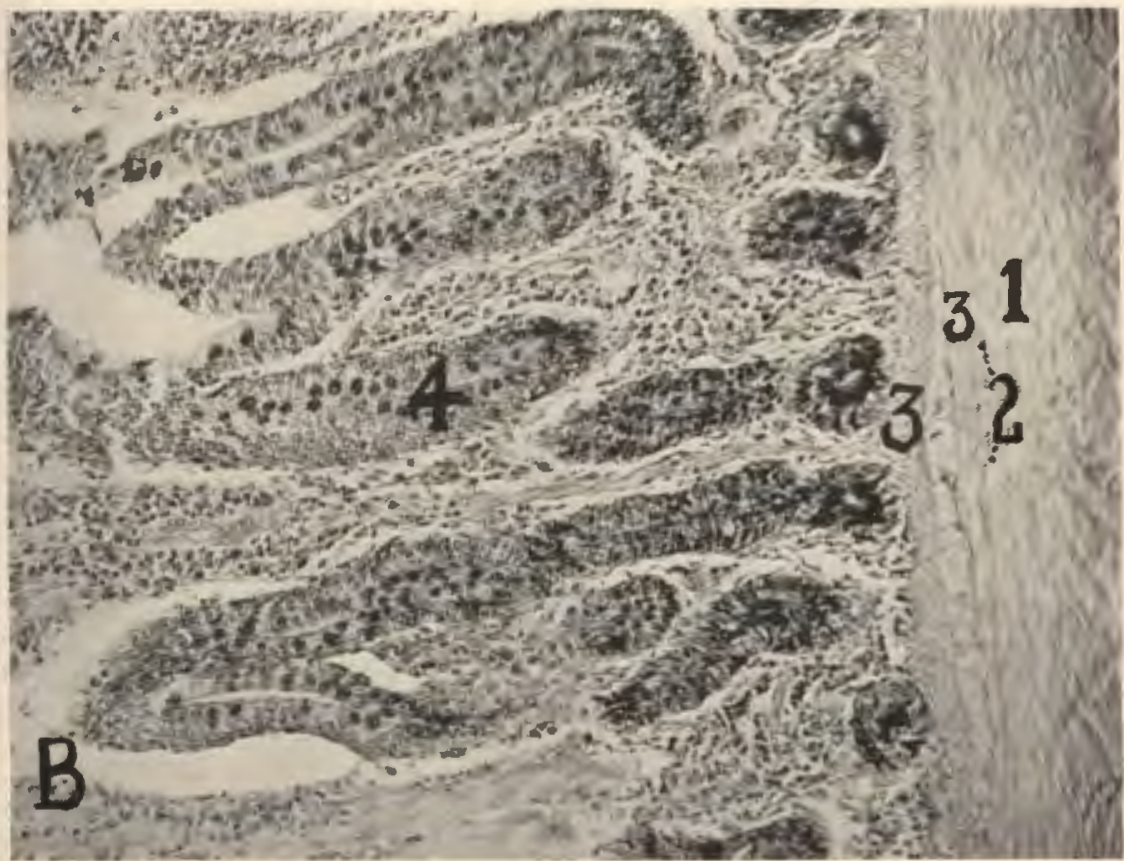

Fig. B. Duodenum stained for mucous glands. Mucous stain. $200 \times .11 / 2$ years.

1. Circular loyer of lómina muscularis

2. Junction of muscularis mucosoe and the circular layer of the lamina muscularis (submucosa)
3. Muscularis mucosae

4. Glands of Lieberkuthn with goblet cells showing mucin 


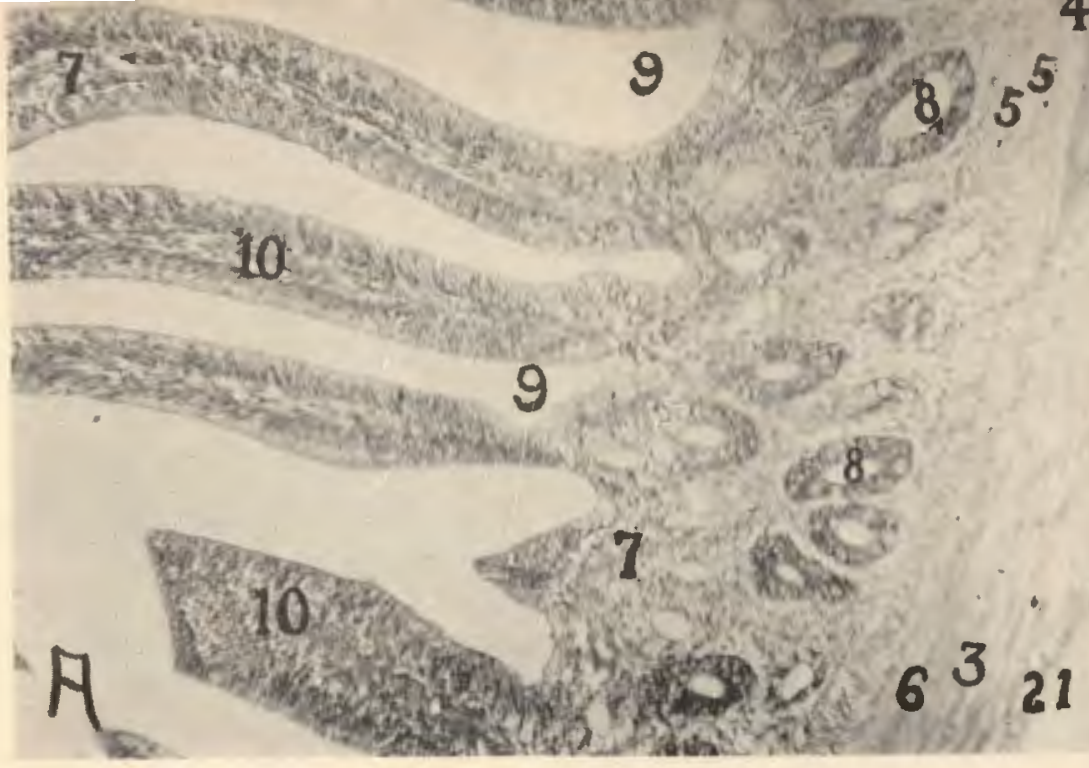

Plate XXVI - Fig. A. Small intestine cross section. Hematoxylin-eosin. $200 \times 20$ days.

1. Serosa

2. Longitudinal loyer of the lamina muscularis

3. Circular layer of the lamina muscu'aris

4. Submucosa

5. Muscularis mucosae
6. Apparent fusion of outer eircular layer of muscularis mucosae and inner circular layer of the lamina muscularis

7. Tuniea propria

8. Glands of Lieberkühn

9. Crypts of Lieberkühn

10. Villi

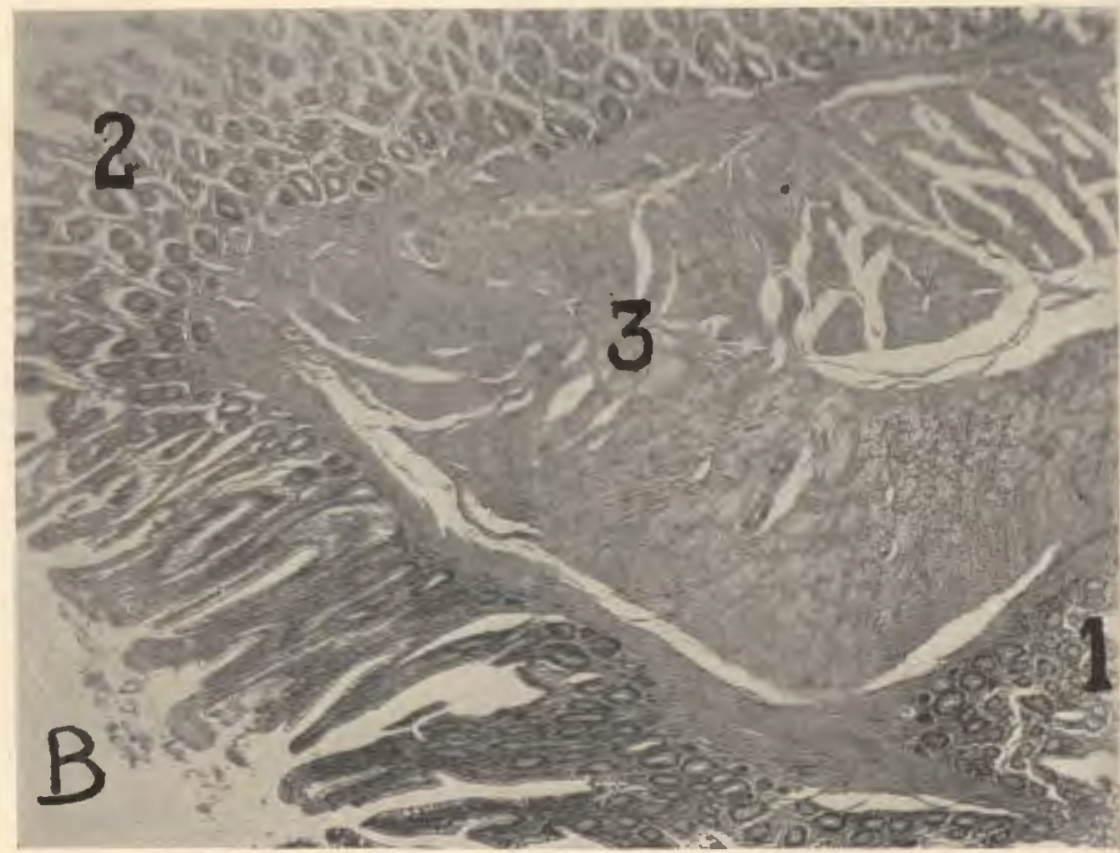

Fig. B. Longitudinal section of the sphincter between the small intestine and rectum. Hematoxylin-eosin. $25 \times$. 11/2 years.

1. Mucosa of the small intestire

3. Muscle

2. Mucosa of the rectum 


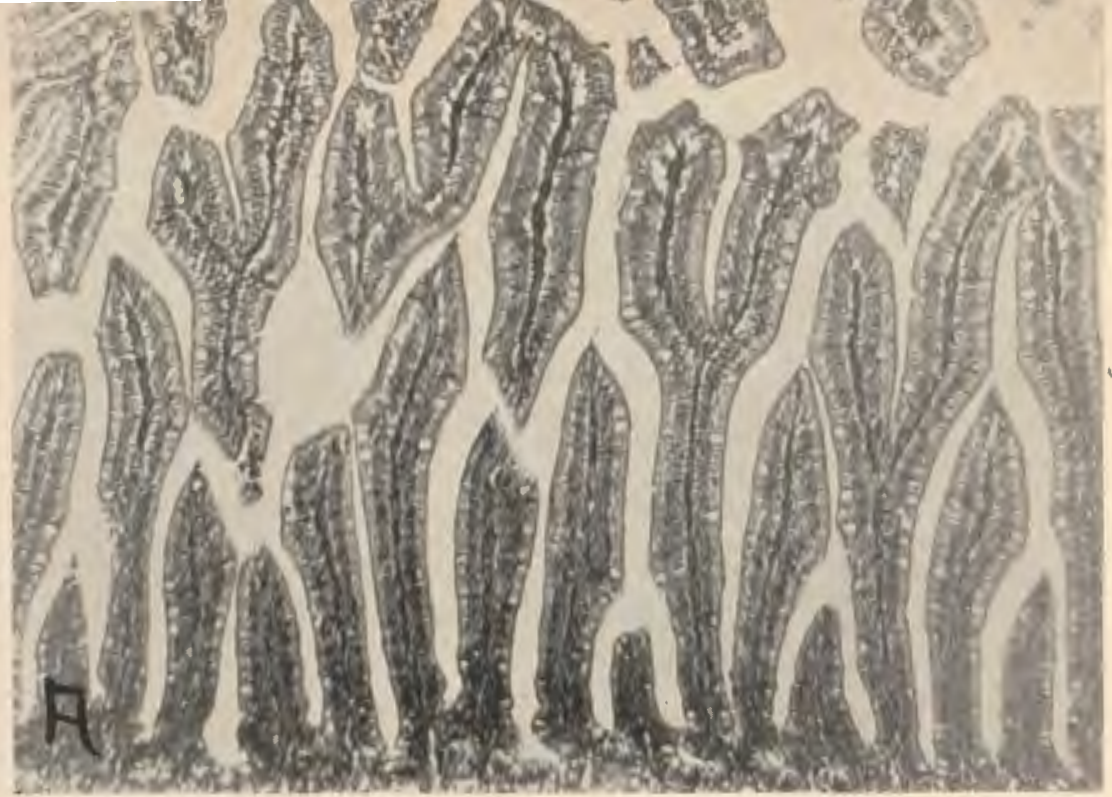

Plate XXVII - Fig. A. Types of duodenal villi. Hematoxylin-eosin. $200 \times .36$ hours.

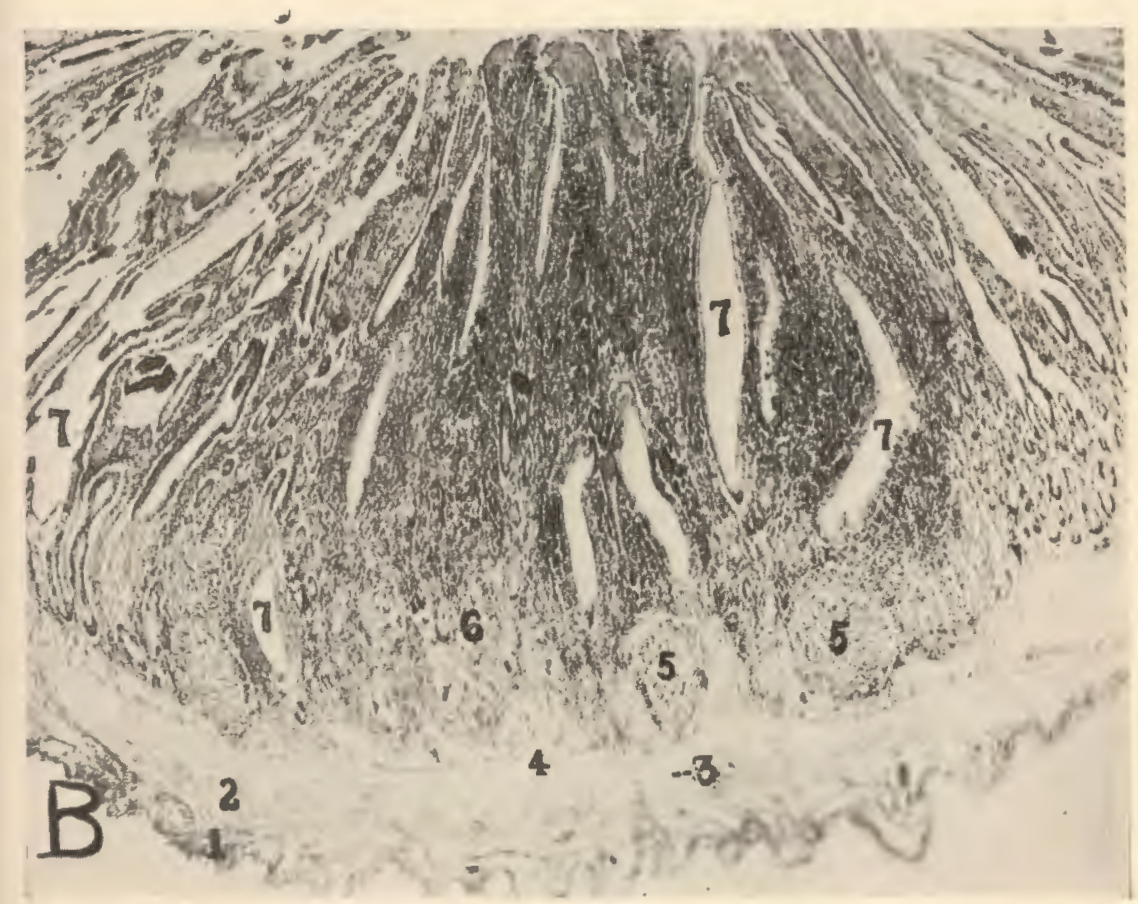

Fig. B. Lymphoid tissue in small intestine. Hematoxylin-eosin. $50 \times .2$ years.
1. Longitudinal muscle
5. Lymph nodules
2. Circular muscle
6. Diffuse Jymphoid tissue
3. Submucosa
7. Crypts of Lieberkühn

4. Muscularis mucosae 


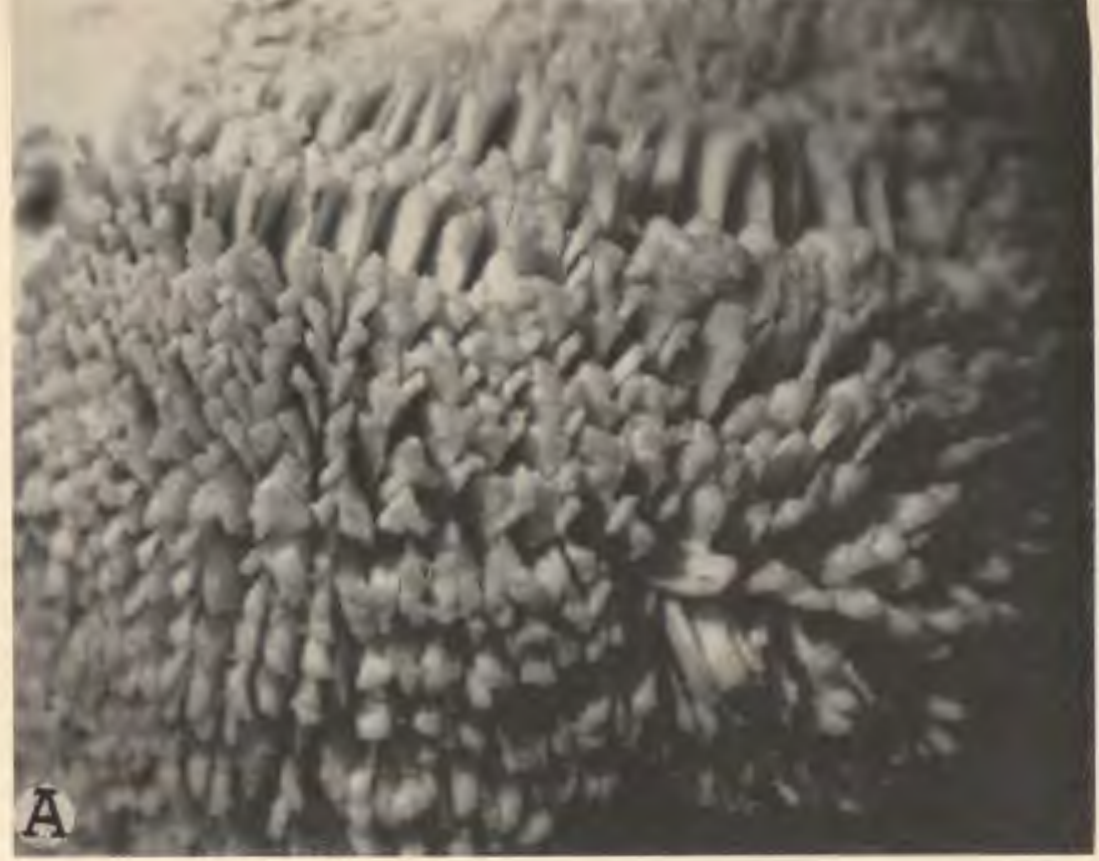

Plate XXVIII - Fig. A. Villi in duodenum. Gross $7.5 \times .4$ months.

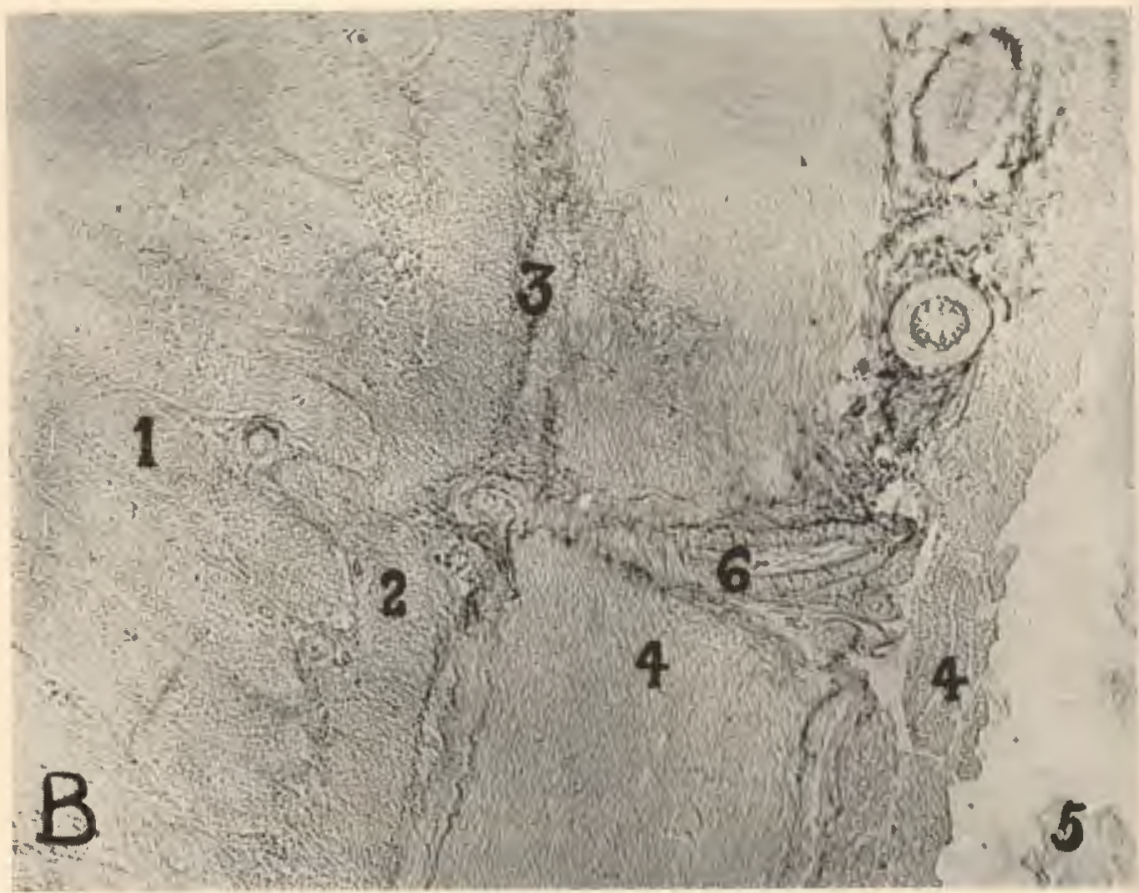

Fig. B. Elastic tissue in duodenum. Weigert's. $200 \times .2$ years.

1. Tunica propria with glands of Lieberkühn

2. Muscularis mucosae

3. Submucosa
4. Lamina museularis

5. Serosa

6. Vessels crossing circular layer of the lamina muscularis 
The subserous layer (Pl. XXVI, Fig. A-1) was very thin, consisting of both white fibrous and yellow elastic fibers. Blood vessels, lymph vessels, and nerves were contained in its meshes. It was limited outside by the peritoneum.

Diffuse lymphoid infiltration of the tunica propria and a few small lymph nodules were observed in the 5-month-old specimen, and in the 2-year-old bird the nodules were so numerous at one place in the small intestine as to appear almost like Peyer's patches (Pl. XXVII, Fig. B-5). A nodule was observed in the circular muscle layer of intestine in the $11 / 2$-year-old specimen.

At a point near the end of the duodenum the pancreatic and bile ducts entered (P1. XXIX, Fig. A-2). There was an elevation in the mucous membrane of the duodenum at this point.

The villi of the duodenum were the longest in all cases. With the exception of the 36-hour chick, the diameter of the small intestine diminished from the duodenum to the rectum. In the 36hour chick the diameter of the duodenum was not so large as the anterior half of the small intestine. In this portion the villi were wider and shorter, even appearing leaflike in some places. 'Toward the posterior portion the villi increased in length again, but the tube decreased in diameter becoming even smaller than the duodenum.

A circular sphincter muscle was observed at the entrance of the small intestine into the rectum (Pl. XXVI, Fig. B-3).

\section{Caeca}

The muscular coats of the caeca were continuous with those from the small intestine and rectum. The general structure of the caeca may be briefly summarized at this point. The structure of the different portions will be discussed later. A mucous membrane lined with columnar epithelium (Pl. XXX, Fig. A-1) containing goblet cells; villi in varying lengths depending on the region (Pl. XXXII, Fig. B-3 and Pl. XXX, Fig. A-2); a muscularis mucosae (P1. XXX, Fig. A-4) absent in places; a submucosa (Pl. XXX. Fig. A-5) of white fibrous and yellow elastic tissue containing nerves, blood vessels, and lymph plexuses; a lamina muscularis (Pl. XXX, Fig. A-6 and 7) varying in thickness and arrangement; and a serosa (P1. XXX, Fig. A-8) rich in nervous elements.

The caeca presented three different pictures depending on whether the proximal, middle, or distal portion was being considered. In Plate XXXII, Figure B-3, even the proximal portion 


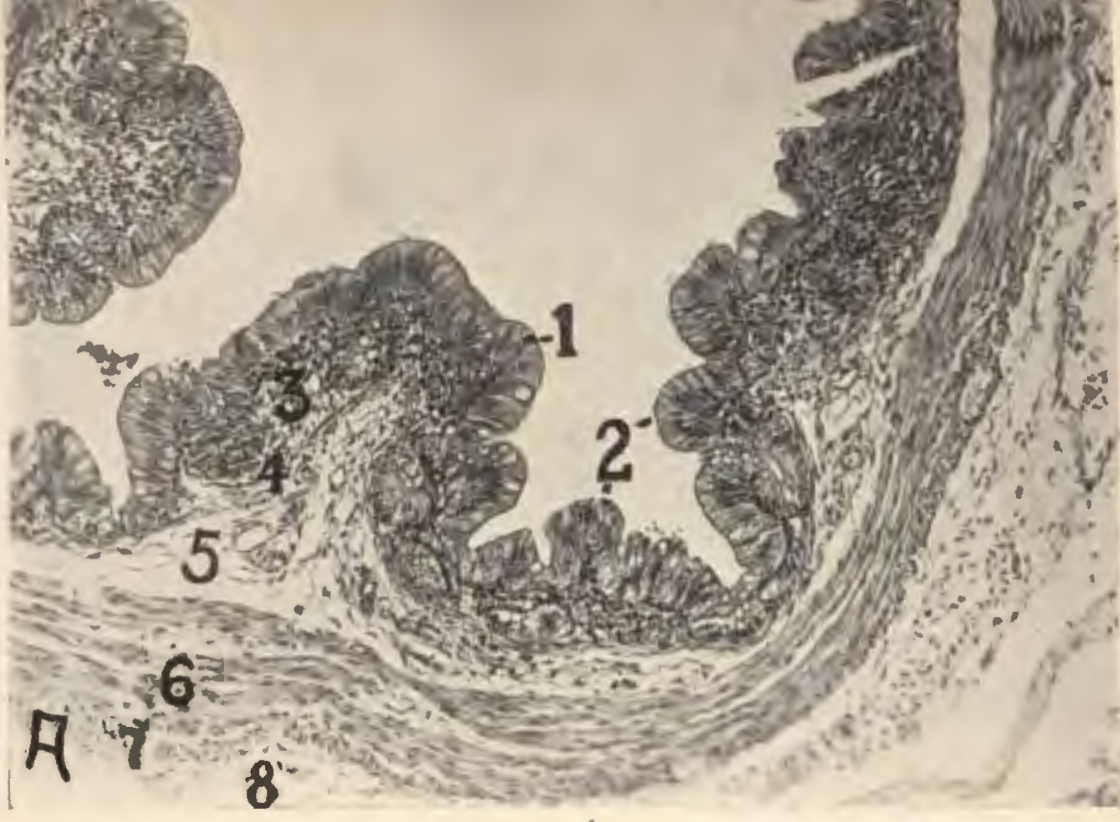

Plate XXX - Fig. A. Caecum, mid-partian, constricted. Hematoxylin-e0sin. $200 \times .36$ hours.

1. Epithelium

2. Villi

3. Tunica propria

4. Muscularis mucosae
5. Submucosa

6. Circular layer of lamina muscularis

7. Longitudinal layer of lamina muscularis

8. Serosa

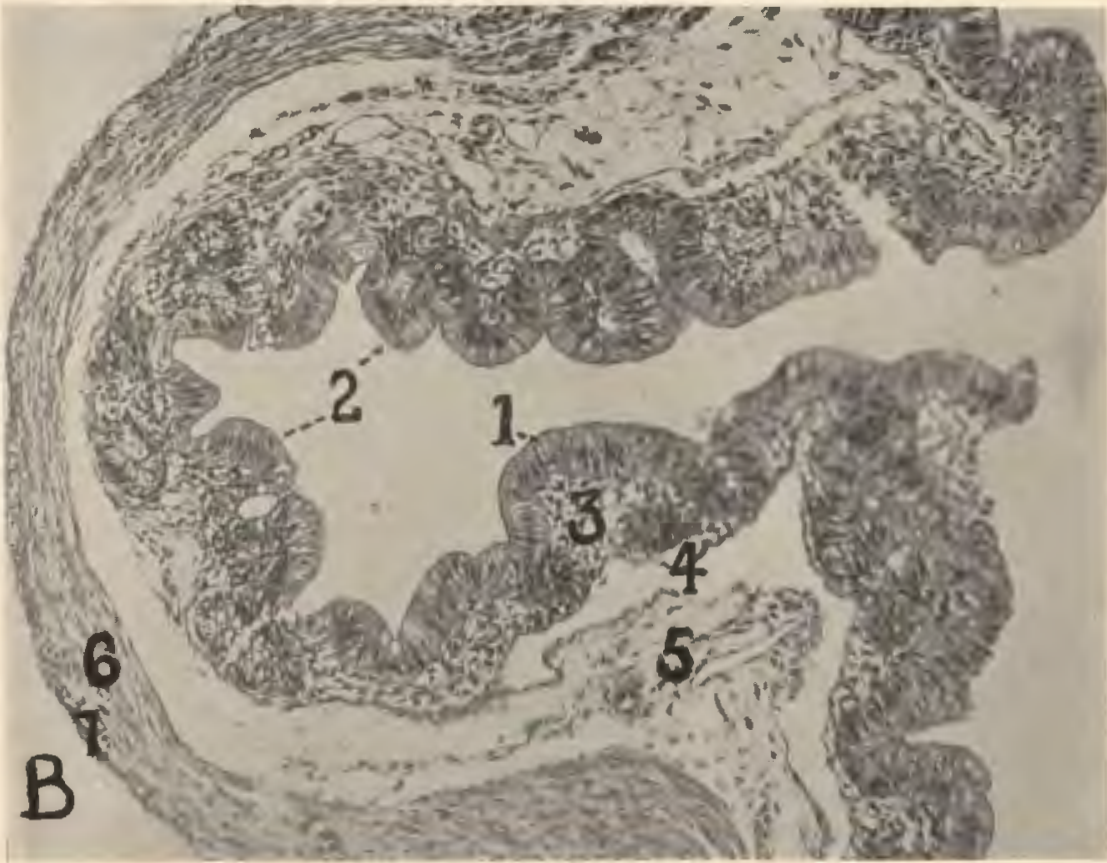

Fig. B. Caecum, mid-portion, dilated. Hematoxylin-eosin. $200 \times .36$ hours.
1. Epithelium
5. Submucosa
2. Villi
3. Tunica propria
4. Muscularis mucosae
6. Circular layer of lamina muscularis
7. Longitudinal layer of lamina muscu- laris 
presented two slightly different views, because of a difference in contraction.

In the proximal portion were prominent villi. They had a structure similar to those of the small intestine. The muscularis mucosae and submucosa were both thin layers and crowded close to the base of the villi. The lamina muscularis was marked by a thick inner circular layer and a thin outer longitudinal laver. No lymphoid tissue was observed in the section of a 36 -hour chick. In a section similarly cut, from a caecum of the 20-day-old chick, one small area of lymphoid tissue was seen. In a caecum of a 5-monthold specimen cut at the same proximal level, the tunica propria was a mass of lymphoid tissue with several nodules. A longitudinal section from the $11 / 2$-year-old specimen showed an extensive area just anterior to the origin of the caeca which was completely infiltrated with lymphoid tissue (Pl. XXXI, Fig. A-4) and contained numerous nodules (P1. XXXI, Fig. A-5).

In the mid-portion the villi were shorter and broader (Pl. XXX, Fig. A-2 and Fig. B-2). Here again the constriction of the wall resulted in a slightly different picture. In a constricted part of the mid-portion the villi were longer, the muscle thicker, and the whole circumference smaller than in a dilated portion at the corresponding level. Plicae circulares were present at this level.

The muscularis mucosae contained a distinct inner circular and an outer longitudinal layer in the 36-hour specimen. No other showed this arrangement definitely. Lymphoid tissue became present with advanced age.

Near the blind end of the caeca of the 36 -hour chick the inner circular and outer longitudinal muscular layers were nearly the same width. True villi were not present. Many eosinophils were present in the tunica propria. The muscularis mucosae was absent in places. Goblet cells were present in the epithelium. No lymphoid tissue was present.

In the distal portion of the caeca of a 20 -day chick the inner circular muscle had increased to about three times the width of the longitudinal muscle. The surface of the mucous membrane approached a villi-like arrangement between the plicae circulares. On the plicae themselves the villi appeared as blunt projections. Eosinophils were numerous in the tunica propria. The muscularis mucosae comprised an inner circular and an outer longitudinal layer. It was present at all points. Goblet cells were observed in the epithelium. Much diffuse lymphoid tissue was present. The 
blind end of the caeca of the 5-month specimen was like the above with many lymph nodules in addition. The $11 / 2$ - and 2-year-old specimens showed the same structure as the 5-month specimen.

\section{Rectum}

The rectum (Pl. XXXII, Fig. A) as a whole resembled the small intestine. Villi were present in all specimens. Scattered lymphocytes were observed in the tunica propria of the 36-hour and 20-day-old chicks, and lymph nodules in the older specimens.

\section{Cloaca}

The cloaca was separated from the rectum by a slight constriction (Pl. XXXIII, Fig. B-5) of the circular muscle forming a somewhat circular orifice. It was not visible from the exterior of the rectum. The cloaca was divided into three parts (Pl. XXXIII, Fig. B and Pl. XXXIV) - coprodaeum, urodaeum, and proctodaeum - by transverse folds. The dorsal fold (PI. XXXIII, Fig. A-1) between the urodaeum and proctodaeum overhung the entrance to the bursa, which was in the dorsal wall of the proctodaeum (Pl. XXXIII, Fig. A-2). The ureters and genital tracts opened on the floor of the urodaeum.

All three parts had a similar 'structure. Villi were- present. They were finger-like in the coprodaeum, but became more leaflike and decreased in height in the urodaeum and proctodaeum.

The cloaca was lined with columnar epithelium which extended as far as the anus. There were plicae circulares present in addition to the folds between the compartments. Lymphoid elements in the tunica propria and elastic tissue throughout the wall increased with the age of the specimen.

\section{Anus}

The anal opening (P1. XXXV, Fig. A-9) was lined with stratified squamous epithelium. The tunica propria at this point contained many papillae. After turning on the inside of the lip the epithelium became thinner; papillae of the tunica propria were absent; and, by the time it reached the fold, it. had become the columnar epithelium of the proctodaeum (Pl. XXXV, Fig. B-4).

The muscularis mucosae was absent in the anus, and the tunica propria and submucosa were fused into a thin, loosely arranged connective tissue layer (Pl. XXXV, Fig. B-2). 


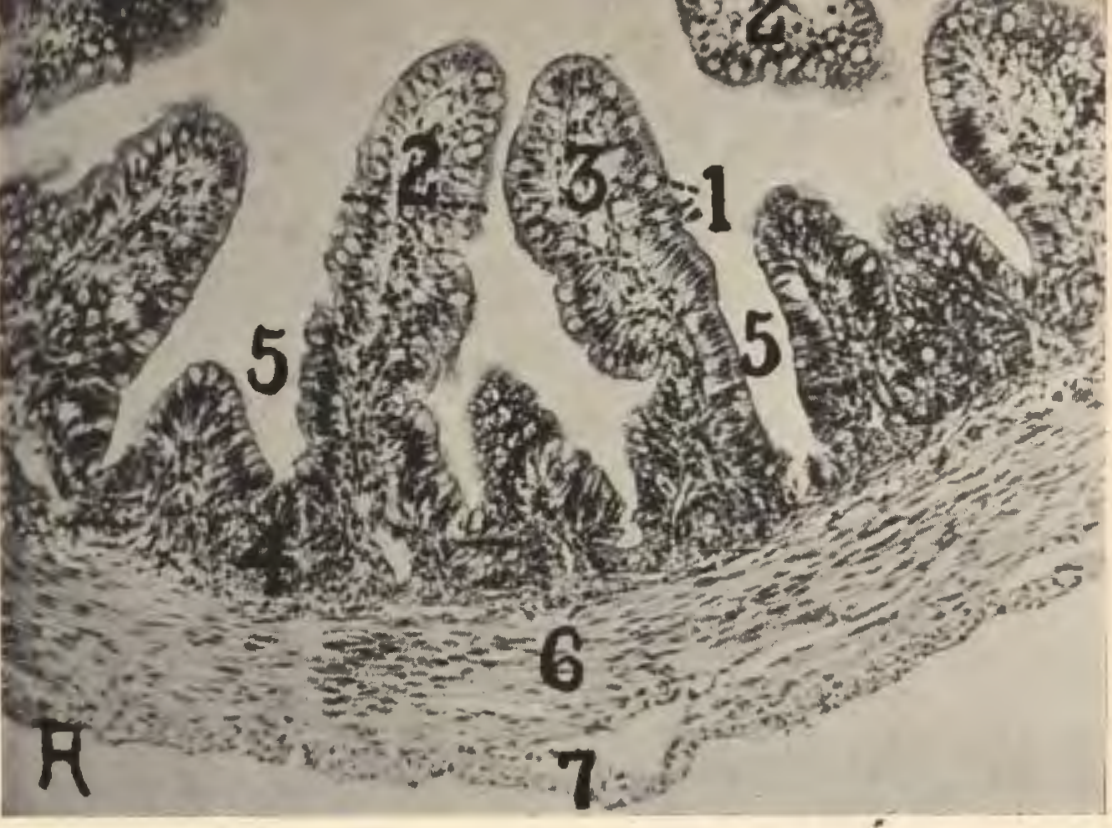

Plate XXXII - Fig. A. Rectum. Hematoxylin-eosin. $200 \times .36$ hours.

1. Goblet cells in the simple columnar

5. Crypts of Lieberkühn epithelium

6. Circular layer of lamina muscularis

2. Villi

3. Tunica propria

7. Longitudinal layer of lamina muscu-

4. Glands of Lieberkühn laris

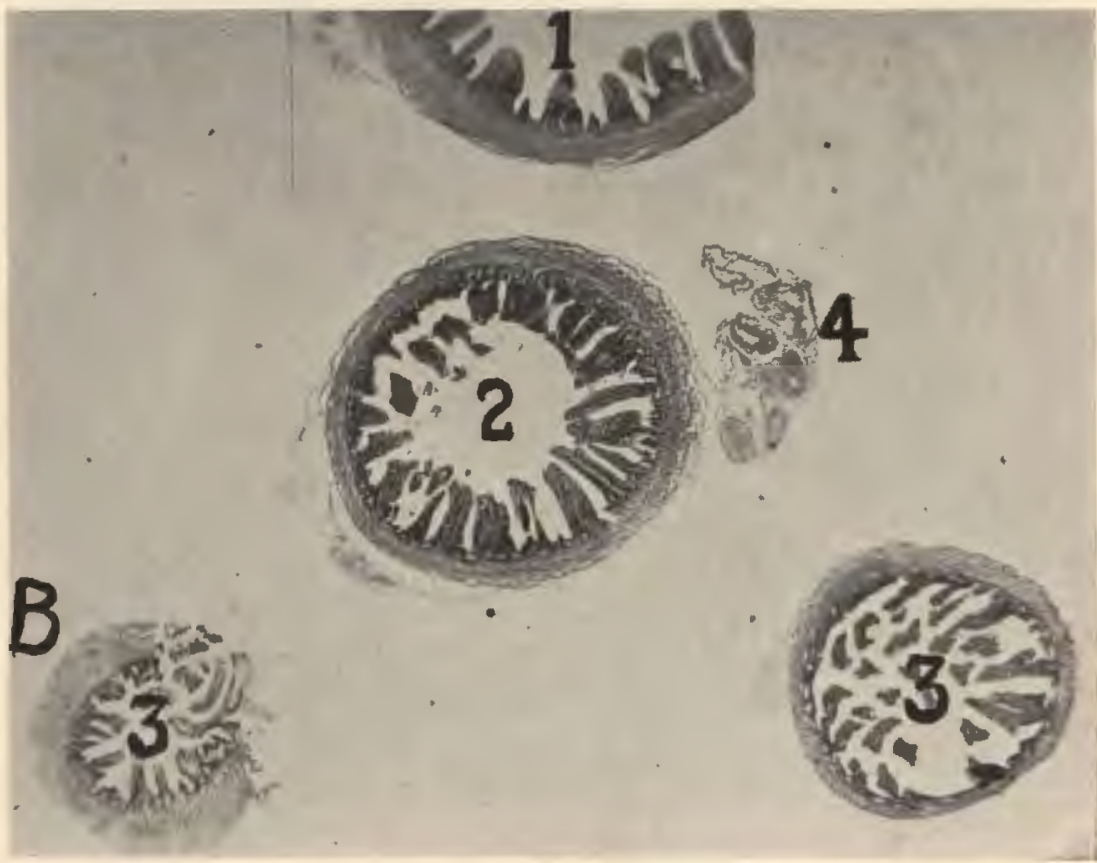

Fig. B. Small and large intestine and both eaeca. Hematoxylin-eosin $25 \times$. 11/2 years. 


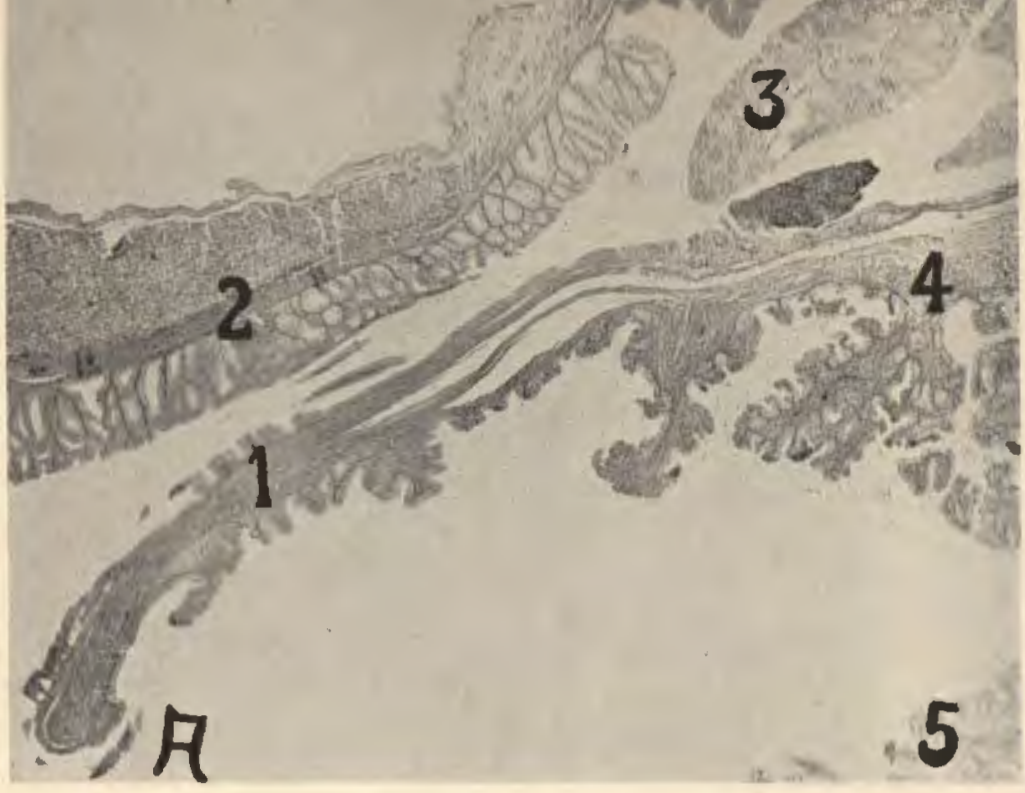

Plate XXXIII - Fig. A. Cloaca showing a fold covering the entrance to the bursa cloa. cae. Hematoxylin-eosin. $25 \times .4$ days.

1. Fold overhanging entrance to bursa cloacae

2. Dorsal wall of proctodaeum

3. Fold of wall of bursa cloacae

4. Dorsal wall of urodaeum

5. Ventral wall of urodaeum

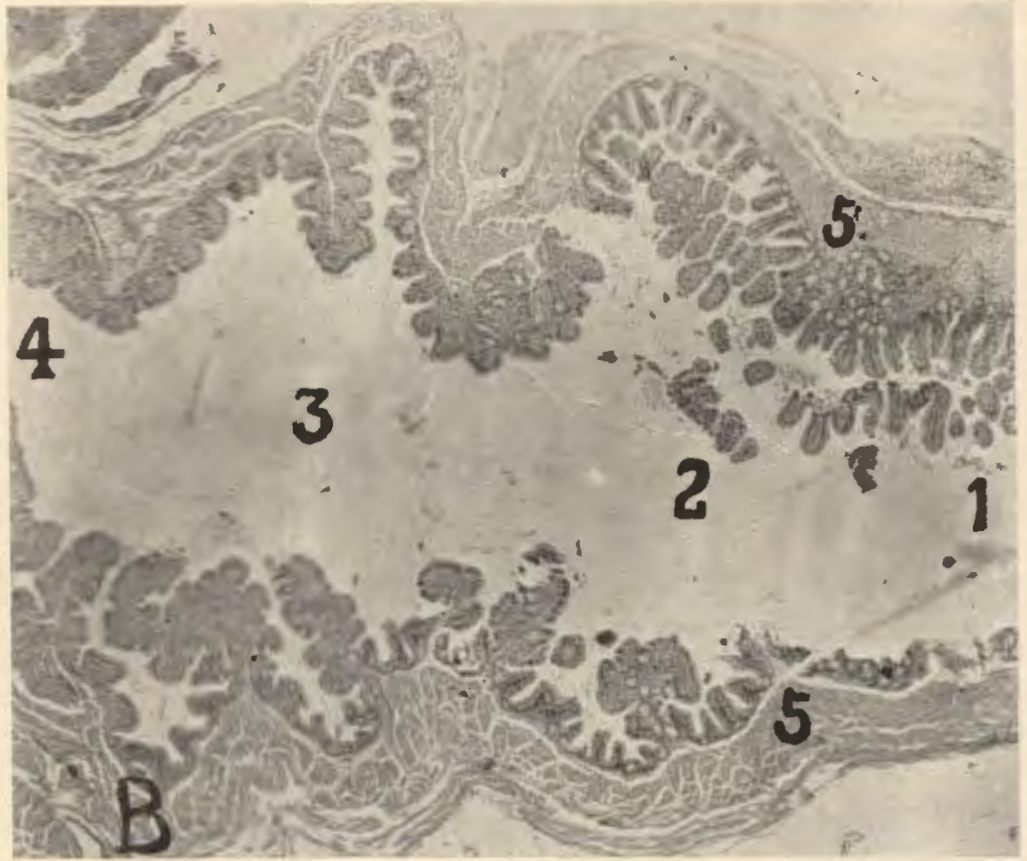

Fig. B. Longitudinal section of the two anterior chambers of the eloaca. Hematoxylineosin. $25 \times .1$ day.

1. Rectum

2. Coprodaeum

3. Urodaeum
4. Proctodaeum

5. Sphincter separating rectum from coprodaeum 


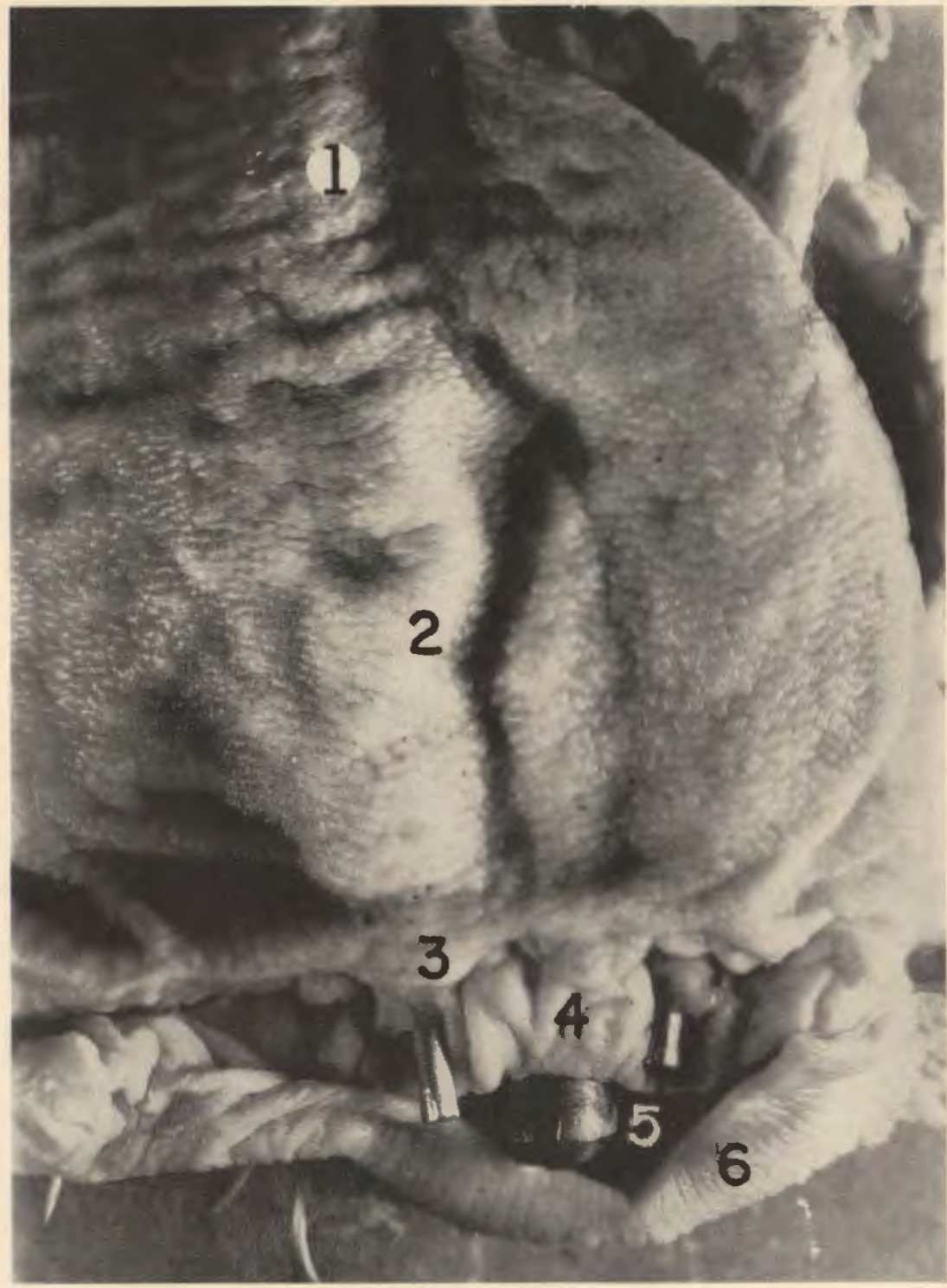

Plate XXXIV - Gross view of open cloaca. Small metal rods show opening of ureters into the wall of the urodaoum. Larger probe indicates opening of the bursa Fabricii into the proctodaeum. $10 \times .4$ months.

1. Transverse folds of the rectum

2. Coprodosum (Note blunt villi.)

3. Fold seporating coprodaeum from urodoeum

\author{
4. Urodaeum \\ 5. Proctodaeum \\ 6. Dorsal lip of the anus
}


Just anterior to the bursa cloacae a voluntary muscle began. It extended as a circular muscle to a point in the wall of the proctodaeum just above the ventral lip of the anus (Pl. XXXV, Fig. A-4). Here the inside portion of the circular layer began to arrange itself in a longitudinal direction. The two portions were continued thus for a short distance. By the time the lamina had reached the furthermost point of the dorsal lip of the anus, its few fibers were all arranged longitudinally (Pl. XXXV, Fig. A-5) .

The muscular arrangement of the ventral lip was a little different. The fibers were circular as above; then a few fibers of the inside portion changed to a longitudinal direction (Pl. XXXV, Fig. A-6) only to change back to a circular arrangement at the extremity of the ventral lip (Pl. XXXV, Fig. A-8).

\section{Liver}

The livers of the five specimens presented one variation - the fat spaces in the liver cells of the baby chicks. This variation will be discussed later. The liver of the chicken differed little from that of the mammal. The interlobular septa were probably less apparent than those of the domesticated animals. The portal canal (Pl. XXXVI, Fig. B) contained the portal vein (1), lymph vessel (4), hepatic artery (3), and bile ducts (2). The interlobular veins were not prominent.

The central veins (Pl. XXXVI, Fig. A-1) were distinguished by the prominent sinusoids which entered them. They were lined with a thin endothelial membrane (Pl. XXXVI, Fig. A-2). The sinusoids were also lined with endothelial cells. The Kupffer cells were definitely marked.

The liver epithelium was arranged in a tubule of foùr to seven cells about an intralobular bile capillary. This tubular arrangement was well marked in a cross section. In longitudinal section these tubules looked like a plate or lamina two cells thick, as Elias and Bengelsdorf (1952) described them (P1. XXXVI, Fig. A). The liver cell was a pyramidal cell with its apex bordering the lumen of the tubule. A large spherical nucleus was in the distal half of the cell.

Elastic tissue was confined to the walls of the blood vessels, to the connective tissue septa surrounding them, and to the capsule of Glisson surrounding the liver. White fibrous tissue was distributed similarly. 
The liver cells (Pl. XXXVI, Fig. A-3) were supported by a meshwork of reticular tissue (PI. XXXVII, Fig. A-2).

Baby chicks were sacrificed daily in an age series from one to 45 days, and the livers were examined microscopically for fat. Grossly these livers appeared yellowish or ochre-colored until about the fifteenth day at which time they began to take on the typical color of the normal adult liver. Microscopically a slight decrease in the amount of fat was observed by the twelfth day (Pl. XXXVIII, Fig. B). By the fifteenth day a considerable decrease was noticeable in the amount of fat (Pl. XXXVIII, Fig. $\mathrm{C})$, and it continued to decrease until on the twenty-first day (Pl. XXXVIII, Fig. E) the fat globules were confined to a small area about the central veins. This condition persisted until about the twenty-fifth day. After this time occasional fat droplets were found scattered throughout the liver. The oldest specimen observed was 45 days old. The adult hematoxylin-eosin-stained specimens showed an occasional vacuole in the liver cells which may have been fat. There were indications that the type of feed and the relation of time of feeding to time of slaughter would change this picture. This phase was considered beyond the scope of this study.

\section{Bile Duct}

The wall of the bile duct consisted of the following layers: an outer adventitial layer; a lamina muscularis with scant outer longitudinal bundles, a prominent middle circular layer, and a somewhat irregular inner layer varying from longitudinal to oblique; a tunica propria extending into longitudinal folds which were covered with villi-like projections; and a simple columnar epithelial lining (Pl. XXXIX, Fig. B).

\section{Gall Bladder}

The gall bladder had a serosal covering which was quite thick and vascular in some areas but thin and avascular in others. Between the serosa and the mucous membrane there were two thin layers of muscle, an inner longitudinal and an outer oblique or circular. The longitudinal layer was quite constant, but the outer layer was occasionally absent. The mucous membrane was a loose connective tissue layer thrown into villi-like folds covered with columnar epithelium. When the organ was distended, these folds were not apparent (Pl. XL). 


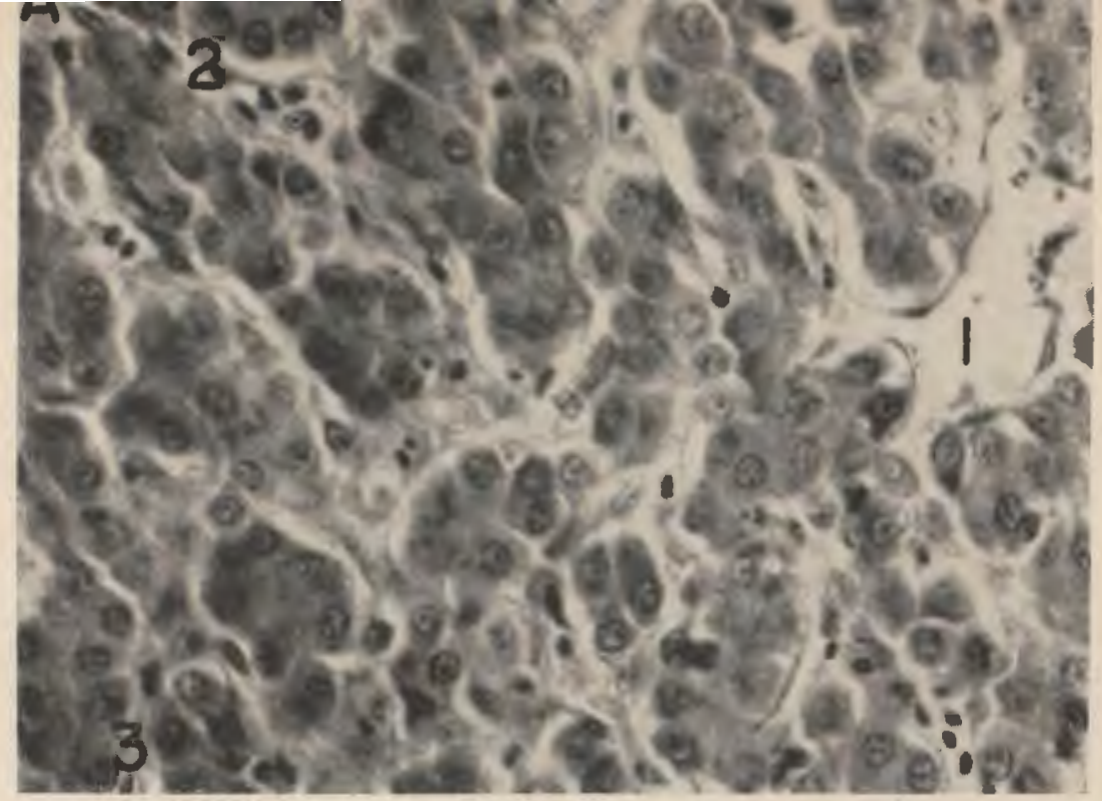

Plate $X X X Y I$ - Fig. A. Liver. Hematoxylin-eosin. $710 \times .2$ years.

$\begin{array}{ll}\text { 1. Central vein with sinusoids opening 2. Cross section of liver cord or tubule } & \text { 2. }\end{array}$ into it

3. Tubule of liver cells cut longitudinally

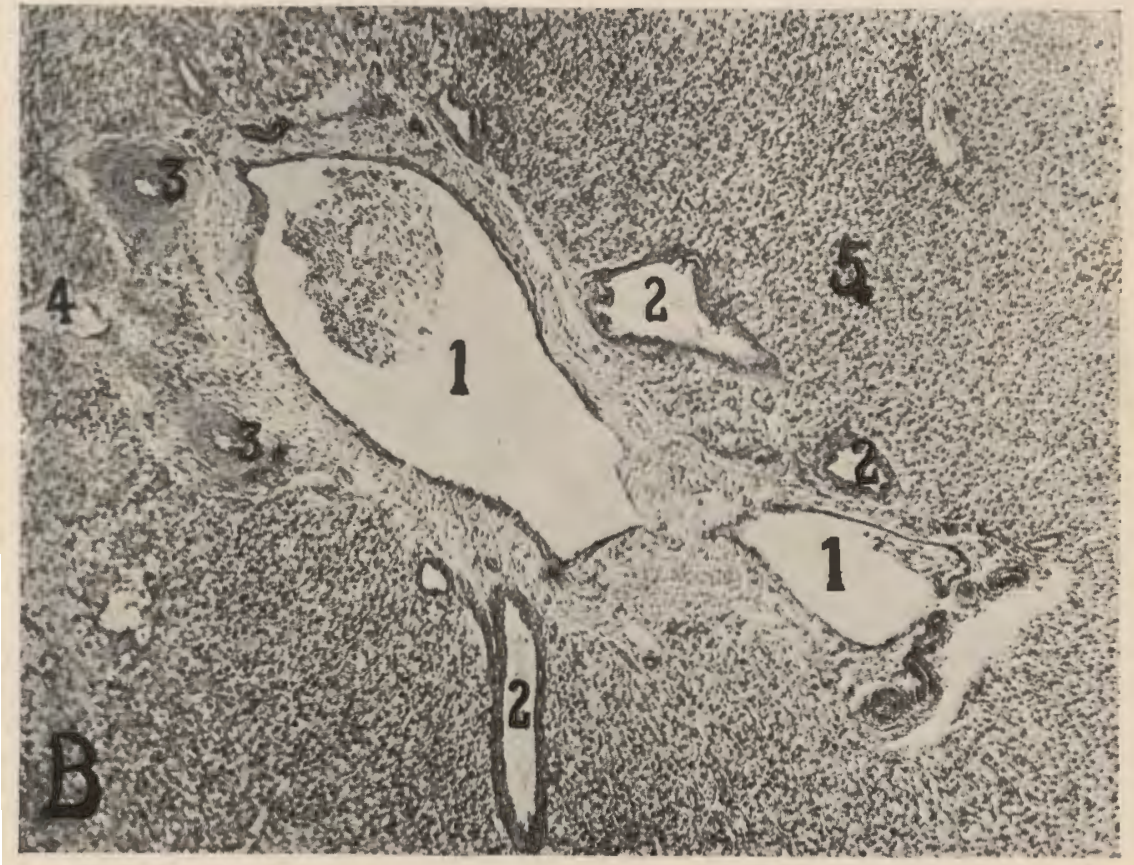

Fig. B. Liver showing portal canal. Note fat spaces in the liver parenchymie. Hematoxylin-eosin. $200 \times .8$ days.
1. Portal vein
4. Lymph vessel
2. Bile ducts
5. Liver parenchyma
3. Hepatic arteries 


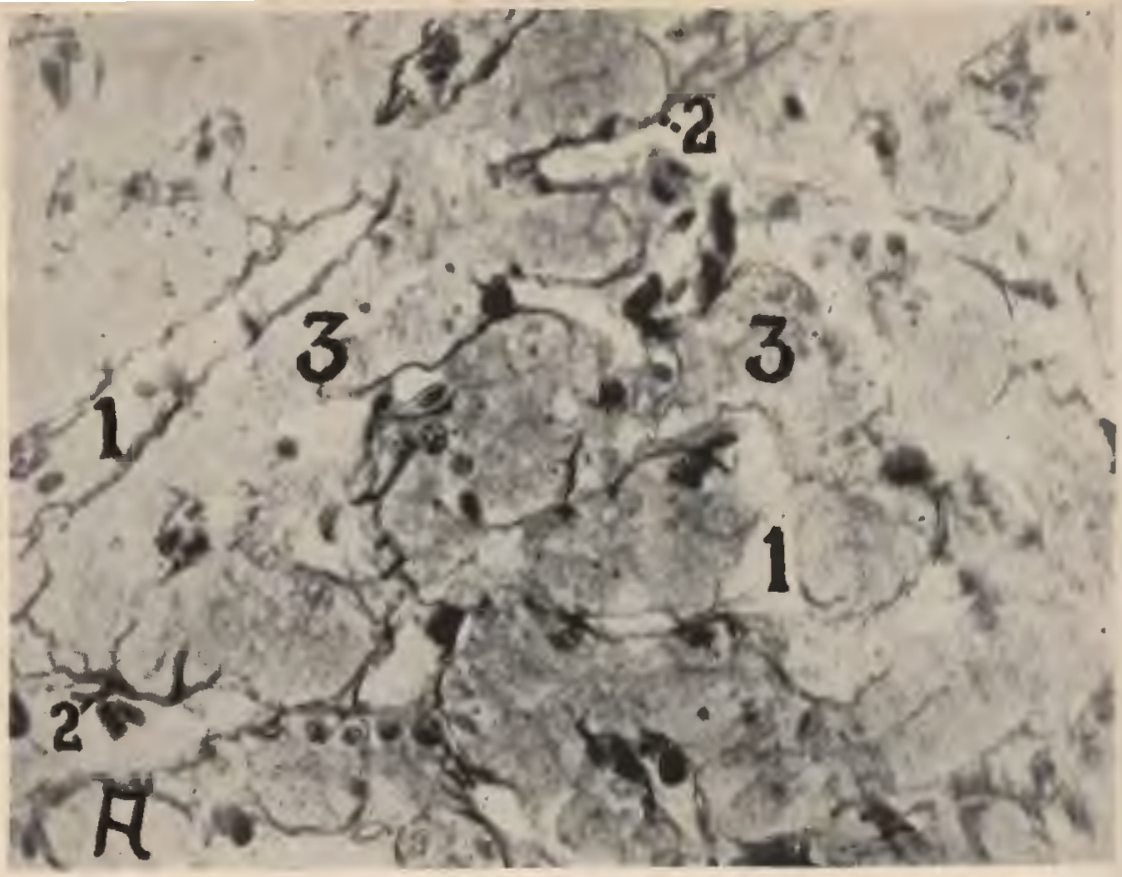

Plate XXXVII - Fig. A. Liver stained for reticulum. Reticular stain. $800 \times$. 11/2 years.

1. Sinusoids

2. Reticulum (black lines)

3. Tubules of liver cells

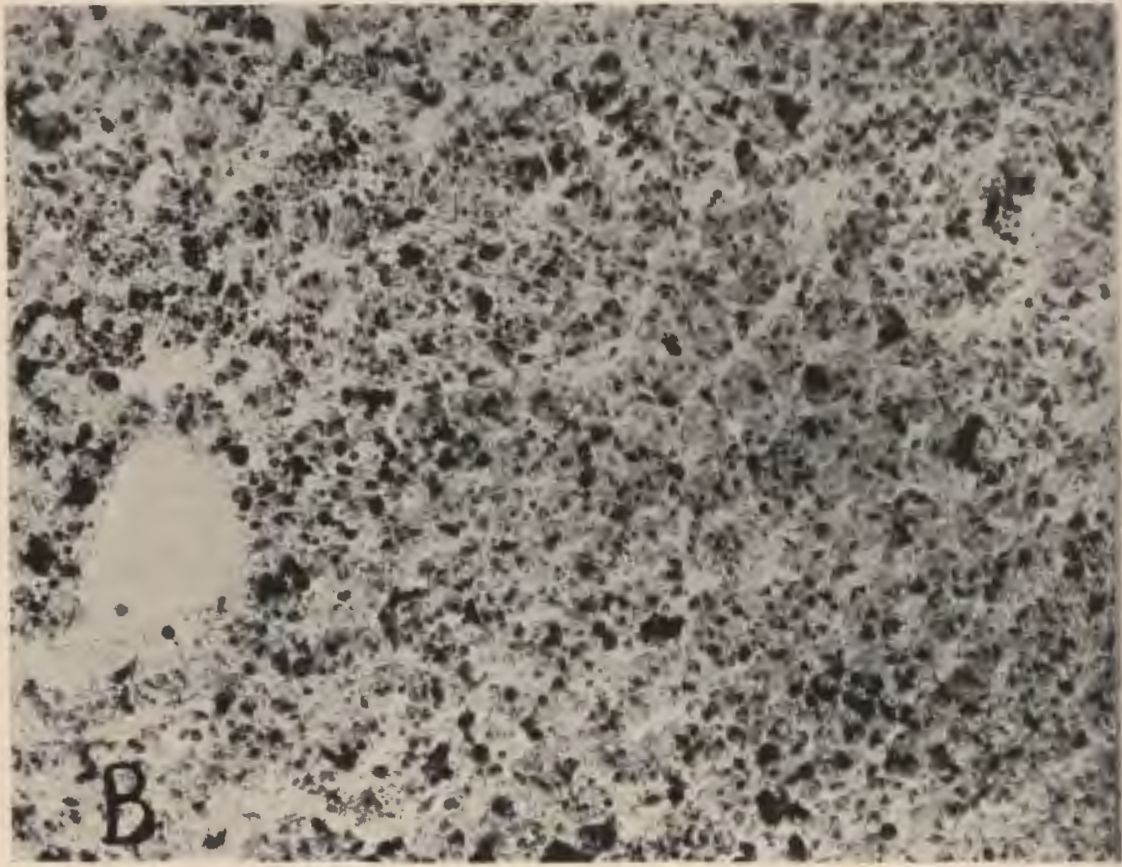

Fig. B. Liver stained for fat. Droplets appear dark. Scharlach R. $200 \times .10$ days. 


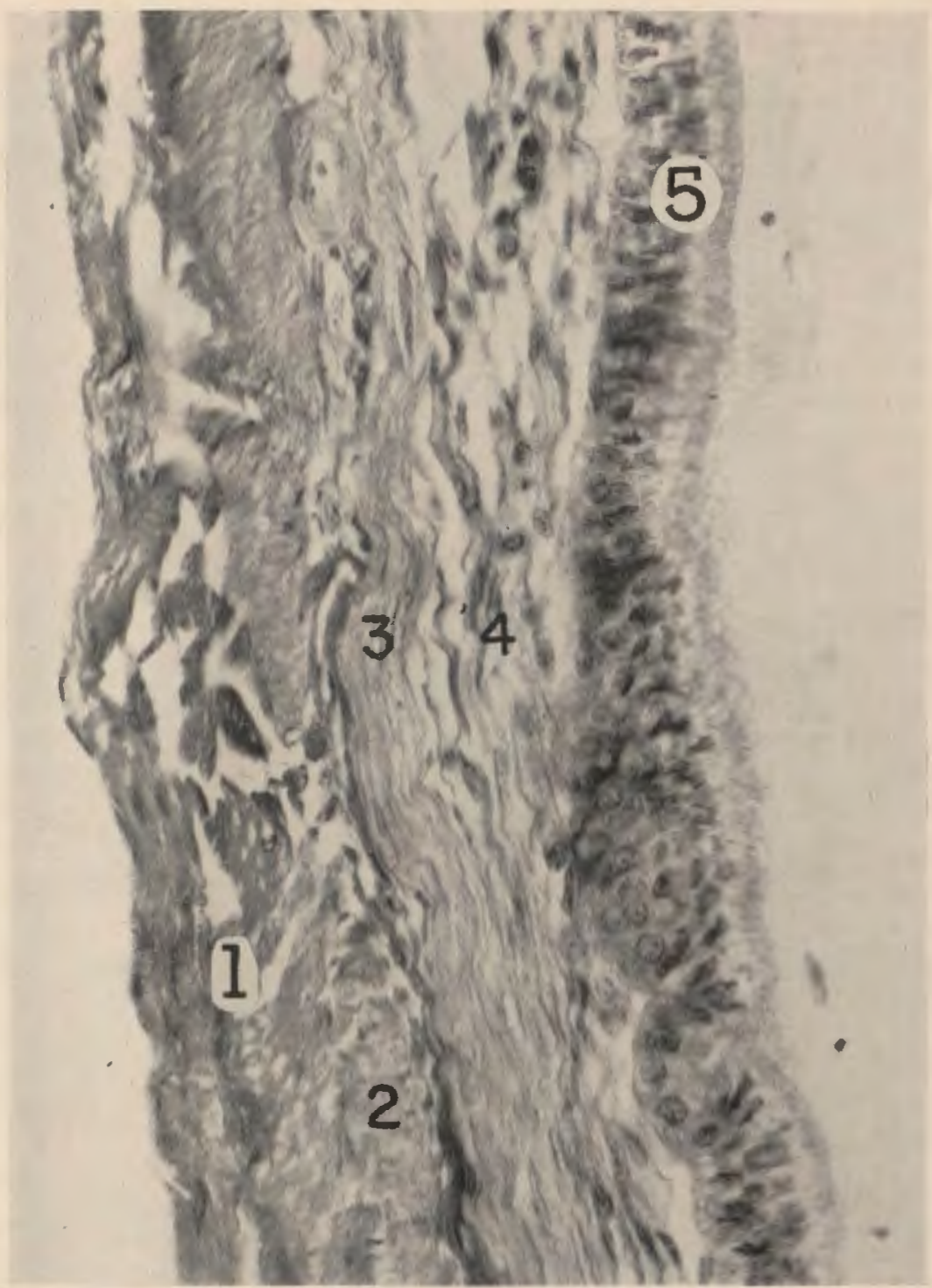

Plate XL - Gall bladder. Longitudinol section. Hematoxylin-eosin. $710 \times .4$ months,

\section{Fibrous serosa}

2. Outer circular layer of the lamina muscularis

3. Inner longitudinal layer of the lamina muscularis

\section{Tunica propria}

5. Simple columnar epithelium 


\section{Pancreas}

The pancreas was a lobulated tubulo-acinar gland, the interlobular septa being very indistinct. The pancreas consisted of many tubular acini (Pl. XLI) which emptied into small collecting ducts lined with flattened epithelium. These ducts in turn emptied into larger ones lined by cuboidal epithelium and so on until the large collecting ducts (PI. XXXIX, Fig. A) with columnar epithelium were reached.

The collecting ducts were seldom seen in the sections, and the exact pattern of the duct system is not understood. Many elongated branching tubulo-acini were observed. As in the duct system, the extent of the tubule and the manner of branching is not entirely clear. It certainly does not present the typical spherical acinus of the mammalian pancreas and salivary glands.

The secretory cells of the pancreas were low columnar and wider at their base than near the lumen. They had a granular cytoplasm, denser near the lumen. The granules were probably similar to the zymogen granules of the mammalian pancreas, although the eosin staining was more uniform throughout the cell. The spherical nucleus was in the basal half of the cell. Centroacinar cells were demonstrable (Pl. XLII) .

Two types of islets of Langerhans were observed. One was the beta islet similar in appearance to those of the mammalian pancreas, containing a few delta cells in addition to the beta cells. The other type was an islet consisting mostly of alpha cells plus a few delta cells. The islet tissue was not separated from the rest of the pancreas by a connective tissue layer. There were small amounts of reticular tissue present in the islets. Elastic and fibrous tissue was confined to the blood vessels and ducts and vicinity, and to the peritoneal covering.

\section{Pancreatic Duct}

The structure of the pancreatic duct was identical to that of the bile duct. Its wall was slightly thicker (Pl. XXXIX, Fig. A).

\section{Bursa Cloacae}

The wall of the bursa cloacae consisted of a thin serosa comprised chiefly of white fibrous connective tissue, an outer circular 


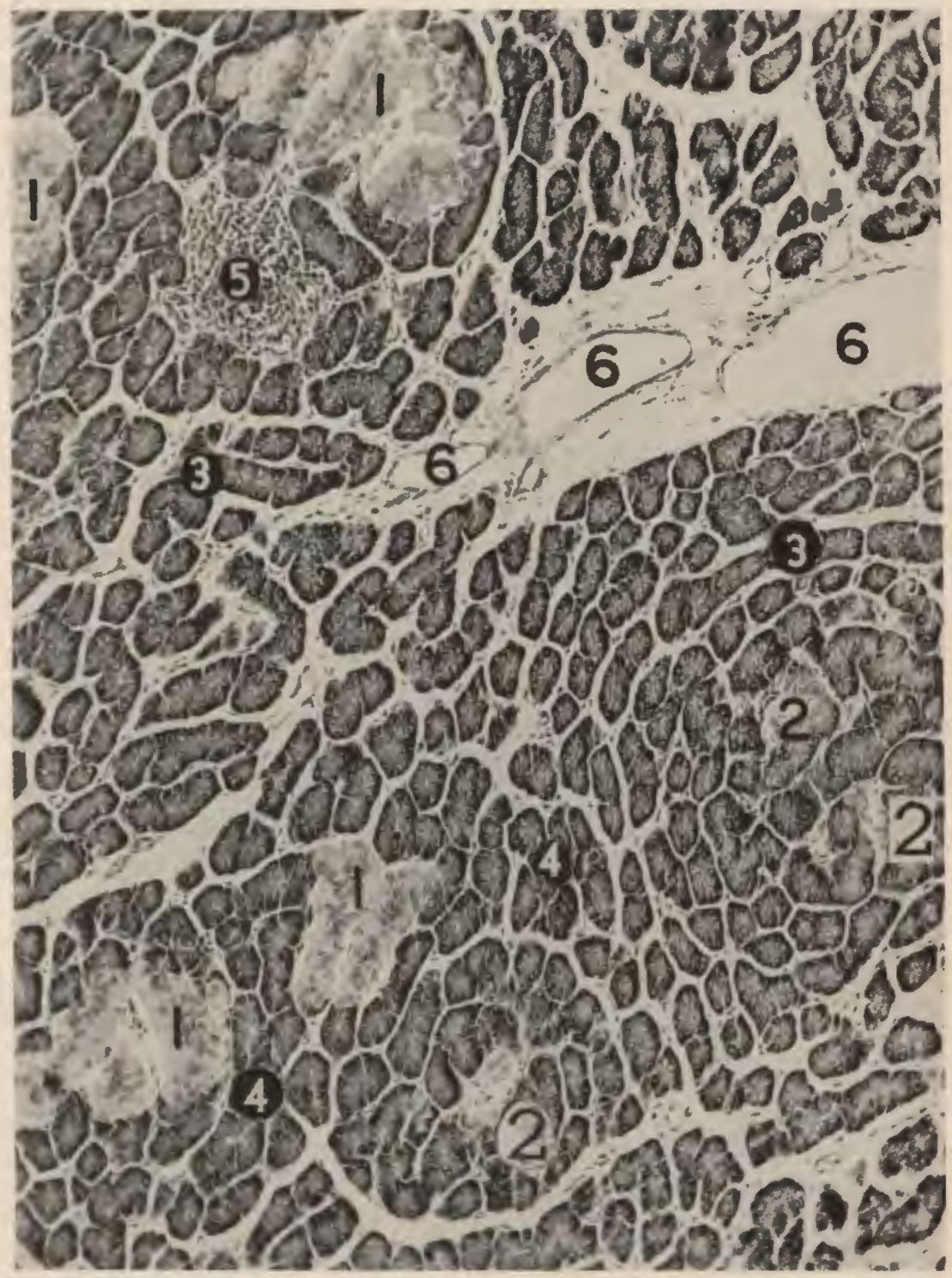

Plate XLI - Pancreas. Note somewhat concentric arrangement of the tubulo-acinar units about the islets. Hematoxylin-eosin. 130 X. 4 months.
1. Alpha islets
2. Small beta islets
4. Note appearance of branching
3. Elongated tubular acini
5. Lymphoid tissue
6. Blood and lymph ressels 
and an inner longitudinal involuntary muscle layer, and a mucosa thrown into longitudinal folds with a structure characteristic of this organ alone (Pl. XLIII).

Some of the muscle fibers joined with white fibrous connective tissue and elastic fibers to form a trabecula (Pl. XLIV, Fig. A-1), which extended the length of the fold and sent septa in between the lymph follicles (P1. XLIV, Fig. A-2). This trabecula was rich in blood vessels.

There were many follicles in a fold. The follicle was a dense lymphocytic structure which was divided into a cortical (Pl. XLIV, Fig. B-4) and a medullary (Pl. XLIV, Fig. B-3) portion, the latter being less dense, comparable to the germ center of a lymph node. This medullary portion was in contact witl the columnar epithelial lining. This epithelium was pseudostratified columnar on and near the tips of the folds. In between tlie folds it appeared as simple tall columnar, although there were areas in which it appeared cuboidal. Goblet cells were present. The medullary portion extended out through the cortical portion to join with an indipping in the epithelium (PI. XLIV, Fig. B-2) . The cortical portion was set off from the medullary portion by a reticular network (Pl. XLV, Figs. A and B) and by a row of cells which appeared similar to a columnar epithelium in places. No blood vessels were observed in the medullary portion but were present in the cortical part.

\section{Yolk Sac}

The wall of the yolk sac consisted of a fibrous connective tissue layer (Pl. XLVI, Fig. B-4) upon which were located many longitudinal folds of columnar epithelium containing many vacuoles (Pl. XLVI, Fig. B-2). The whole was surrounded by a serous membrane (Pl. XLVI, Fig. B-5).

\section{Yolk Stalk}

The wall of the yolk stalk was similar to that of the intestine with which it was continuous. A lamina muscularis, comprised of an outer longitudinal and an inner circular muscle (Pl. XLVI, Fig. A-2), and a muscularis mucosae with both longitudinal and circular fibers (P1. XLVI, Fig. A-4) made up its muscle. The submucosa was thin (Pl. XLVI, Fig. A-3). The tunica propria (Pl. XLVI, Fig. A-5) was a dense connective tissue layer arranged in villi-like projections which were covered with a simple colum- 


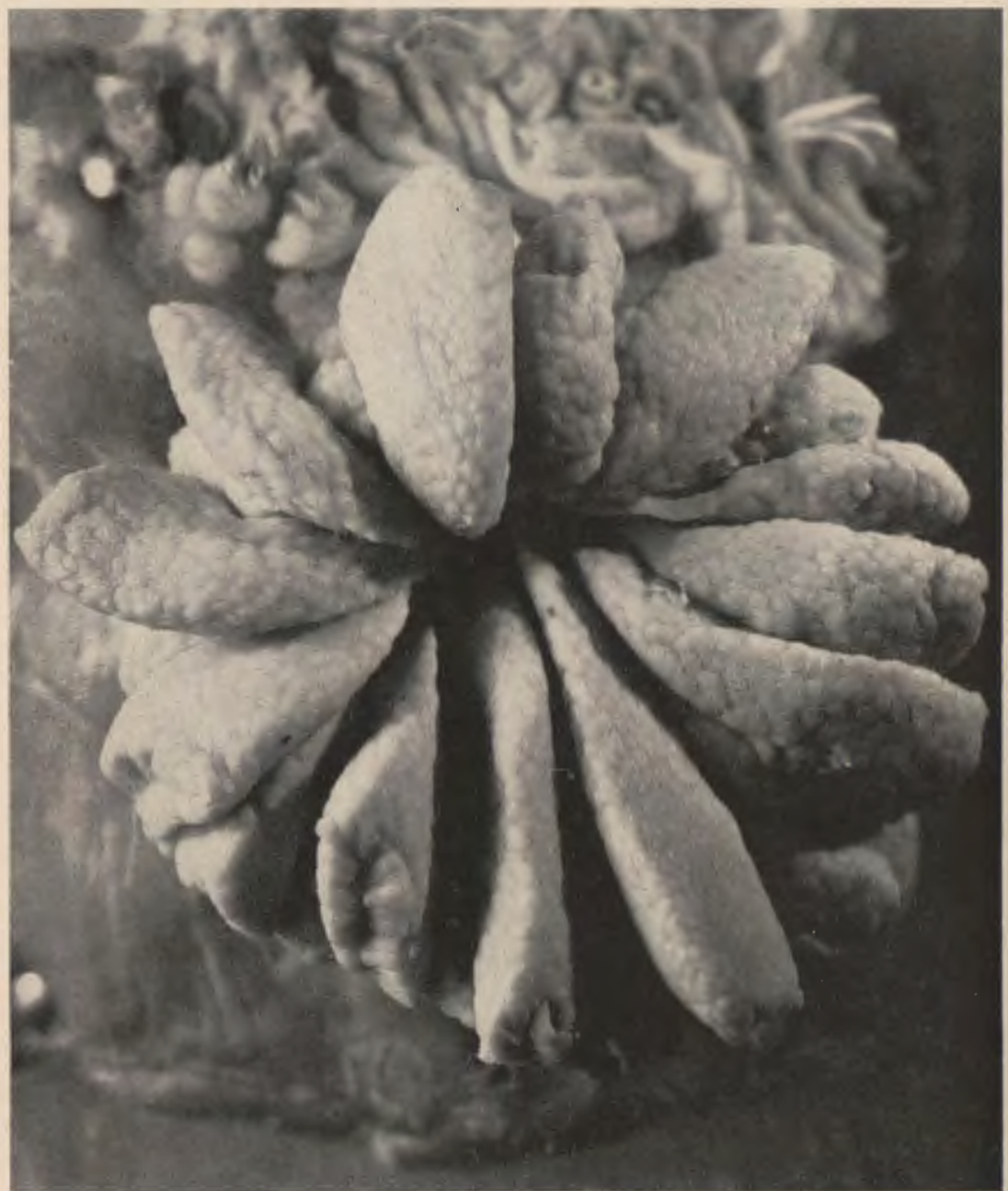

Plate XLIII - Bursa cloaca. The blind end was cut and the organ everted. Note the shape and extent of the folds and the gross appearance of the lymph follicles. Gross. $3 \times .4$ months. 


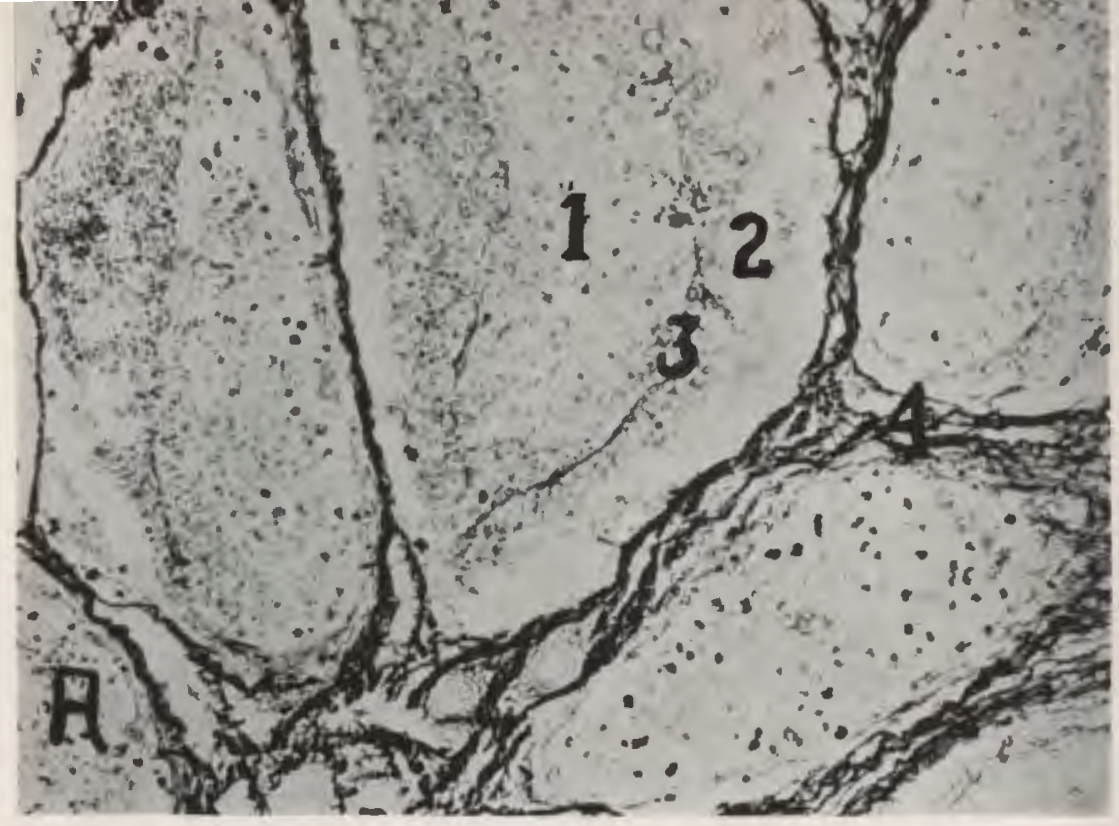

Plate XLV-Fig. A. Fold of the bursa cloacae showing reticulum. Reticular stain. $200 \times$. 7 months.

1. Medullary portion of lymph follicle

2. Cortical portion of lymph follicle

3. Reticular tissue at junction of medul. lary and cortical portions

4. Interfollicular septa

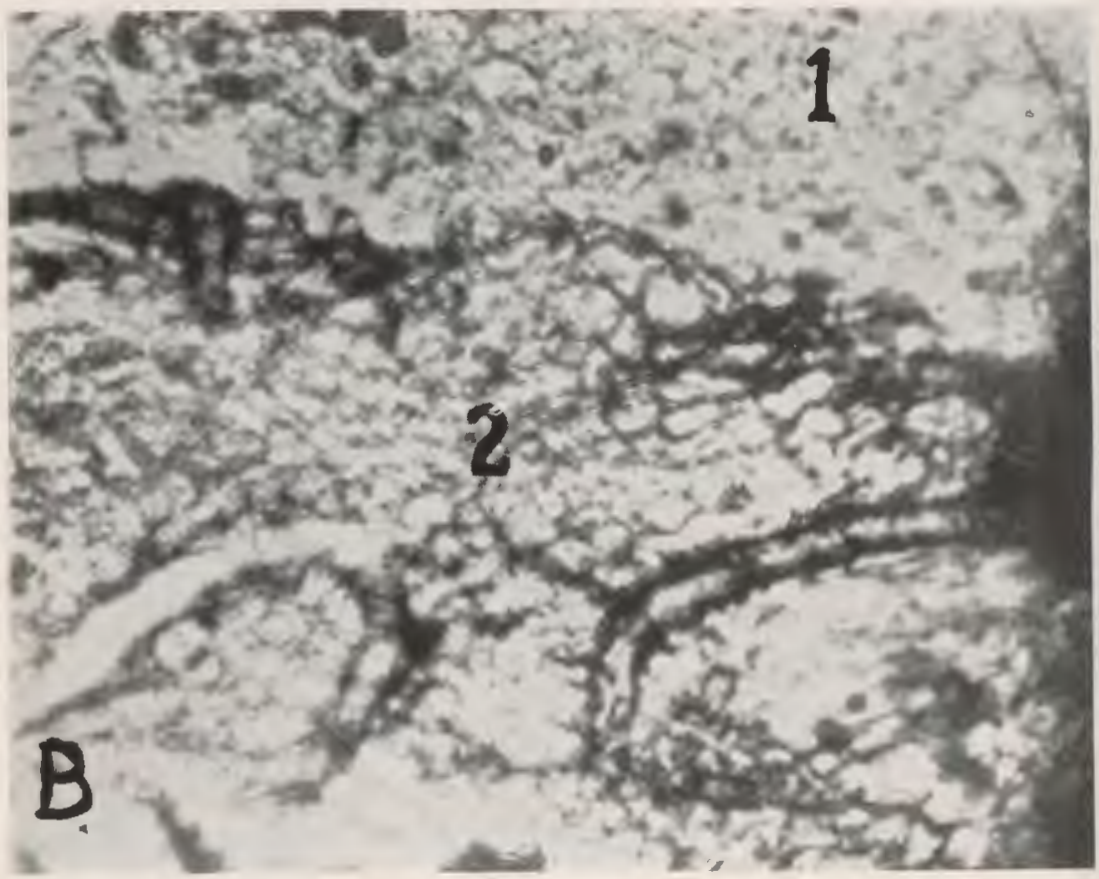

Fig. B. Reticulum separating cortical from medullary portions in a follicle of the bursa cloacae. Reticular stain. $800 \times, 7$ months.

1. Cortical portion

2. Medullary portion 


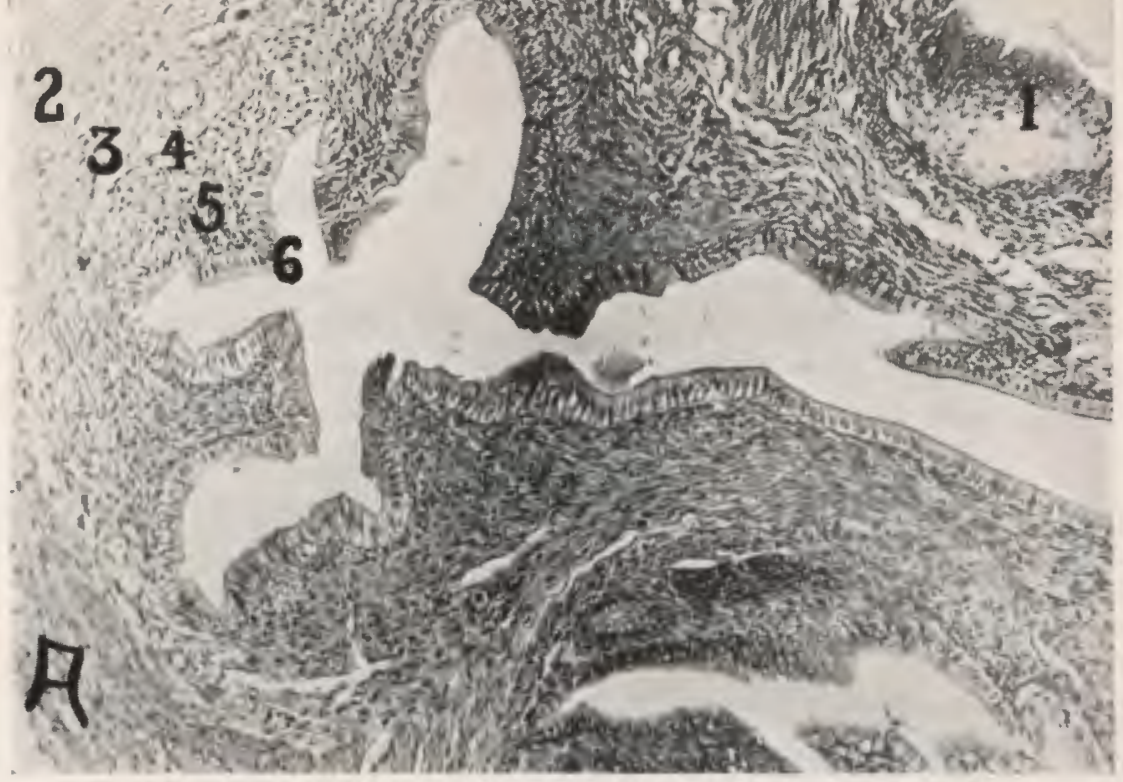

Plate XLVI - Fig. A. Yolk stalk. Hematoxylin-eosin. $200 \times .36$ hours.
1. Intestinal mucosa
4. Muscularis mucosae
2. Lamina muscularis
5. Tunica propria
3. Submucosa
6. Columnar epithelium

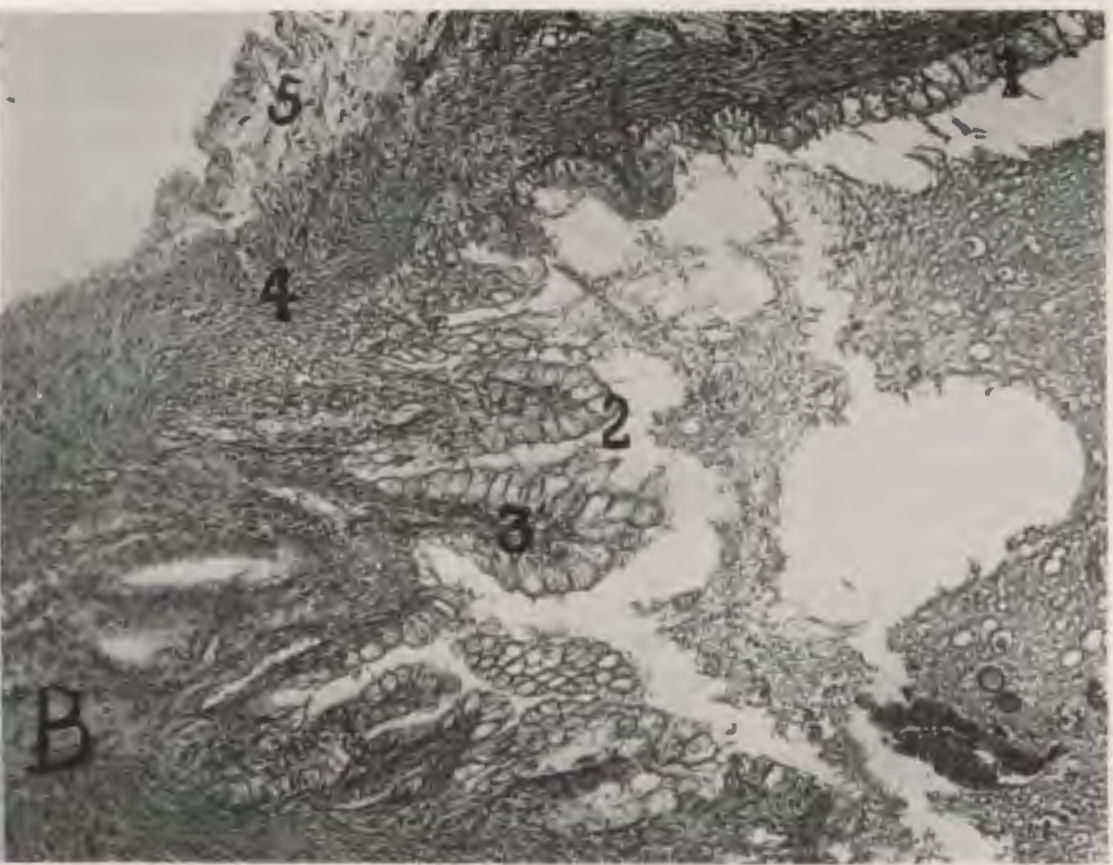

Fig. B. Yolk sac. Hematoxylin-eosin, $200 \times .1$ day.

1. Cuboidal epithelium of yolk stalk

2. Columnar epithelium of yolk sac

3. Folds in the mucaus membrane
4. Fibrous connective tissue layer

5. Serosa 
nar epithelium (Pl. XLVI, Fig. A-6). Few goblet cells were observed.

In the 36-hour chick no lymphoid tissue was observed, but in the $11 / 2$-year-old specimen it resembled the proximal part of the caeca, the lymphoid tissue was so large in amount.

Another section taken from a laboratory dissector of unknown age (adult) showed a wall of four layers: the inner, a columnar epithelial layer (no folds or crypts) ; the second, a lymphoid layer which had obliterated the tunica propria; the third, a thick circular muscle layer; and the outer, the serosa.

\section{DISCUSSION}

According to Krause (1922), there are four layers in the beak, but the author observed only three. The corium consisted of one layer and was not divided into two as Krause described it.

No evidence of teeth was found, thus agreeing with previous authors.

A hard palate was present, but no soft palate was observed. This was in agreement with Heidrich (1905), Ward and Gallagher (1926), and Bradley and Grahame (1951).

There was no microscopic line of demarcation between the mouth and pharynx, but the last row of papillae on the hard palate and those at the base of the tongue seemed to divide these two cavities. If one considers these as boundaries, then it may be stated that there is an exact line of demarcation between the mouth and the pharynx. Heidrich (1905), Grossman (1927), Bradley and Grahame (1951), and Foust (1952) used these as convenient marks for separating the two. The author agrees with Heidrich that the muscularis mucosae began in the posterior part of the pharynx but cannot agree with him on the musculature of the pharynx. Heidrich (1905) stated that the pharynx had no muscle. A thick muscle inserted itself obliquely in the wall of the pharynx.

Taste corpuscles were not observed.

A tonsil as such is not regarded as a structure belonging to the chicken. There was present only a lymphocytic infiltration of the tunica propria with some lymph nodules present. This was observed only in adult birds and was particularly prominent in the region of the aditus laryngis. Killian (1888) described a tonsil in the region of the Eustachian tubes.

Schauder's (1923) classification of the salivary glands was fol- 
lowed. The structure of these glands was found to be similar, in agreement with Kovacs (1928). Heidrich (1905) found basket cells, while Holting (1912) did not. The author did not definitely determine whether basket cells were present or not. Heidrich studied also the changes taking place in the gland in the physiologic state, but this was not considered in the present study.

In agreement with Barthels (1895), Heidrich (1905), Kaupp (1918), Browne (1922), Batt (1925), Kovacs (1928), and Bradley and Grahame (1951), the author found the outer layer of the lamina muscularis of the entire digestive tract (except the gizzard) to be longitudinal.

The esophageal tonsil of Zietschmann (1911), Schauder (1923), and Kovacs (1928) was not observed. There were four layers in the wall of the esophagus as Marschall (1895), Batt (1925), and Grossman (1927) have agreed. The detachment of the surface layers of the mucosa, as observed by Barthels (1895), was also observed by the writer.

The author found that the crop had the same general structure as the esophagus. In agreement with Barthels (1895), no glands were found in the diverticulum of the crop but were confined to the area adjacent to the esophageal wall.

The macroscopic structure of the papillae on the inside of the proventriculus was described in some detail. The concept of superficial tubular glands was found to be erroneous as Elias (1945) reported. These were merely simple columnar epithelial cells covering the plicae and lining the sulci which were between them.

The glands of the proventriculus were multilobular. Schreiner (1900) and Zietschmann (1911) also described them as multilobular. No evidence was found that would lead one to say that there was a variation in size of the glands in different regions of the proventriculus. Wilczewski (1870) thought they were larger at the esophageal end and smaller toward the gizzard, and Marschall (1895) found them to be small in size at both extremities. There was some variation in the size of the lobules but this may have been because of the way they were cut. It is doubtful if one should try to compare the glands of either the proventriculus or the gizzard to regions in mammalian stomachs, as did many authors, because the variation is too great.

There were reasons to support Zietschmann's (1911) and Bradley and Grahame's (1951) idea that the deep glands were 
beneath the muscularis mucosae and that the lamina muscularis had three layers, because of the fact that there was much connective tissue about the glands. This could easily be taken for the submucosa as there was such a thin layer of connective tissue between the two inside muscle layers. However, there were fibers from the inner longitudinal layer which coursed in between the glands; hence, the inner longitudinal muscle layer was considered the muscularis mucosae. This is in agreement with Batt (1925).

The section of the gut between the proventriculus and gizzard was characterized by the lack of deep propria glands as Cazin (1886b), Hässe (1886), Zietschmann (1908), Schauder (1923), and Kovacs (1928) described.

There was little disagreement on the structure of the mucous membrane of the gizzard, and the findings in this study agreed with those of previous authors. However, elastic tissue was not confined to an area beneath the gland region alone as Zietschmann (1911) said, but was also found in the tunica propria of adult specimens and in the subserous layer. The thin outer longitudinal muscle which Batt (1925) described was not observed in any specimens studied.

The muscles were found to be invaded by a network of white fibrous connective tissue. White fibrocartilage was observed between the fibrous aponeurosis and the muscle mass presumably serving to make a stronger connection between the two. Skeletal muscle as described by Bradley and Grahame (1951) was not observed. However, heavy contraction bands were seen in the keel area and presented a microscopic appearance similar to their description of "striated" muscle.

Neither the fold described by Marschall (1895) and Kaupp (1918) nor the valve mentioned by Otte (1928) was observed between the gizzard and the duodenum.

A thin submucosa was found in the small intestine. This finding was in contrast to Cloetta's (1893) idea that the submucosa was absent and that the blood and lymph vessels were in the tunica propria. The outer layer of the muscularis mucosae was so intimately associated with the circular layer of the lamina muscularis that the submucosa was not discernible in places.

The two bile and three pancreatic ducts entered through a papilla as described by Gadow (1879) . 
There was evidence that the structure of the villi changed with age in accordance with Bujard's (1906) observations, because the villi of the 36-hour chick had a somewhat different aspect than that of all the other specimens studied. The villi were leaflike in some parts of the small intestine at this age. No observations were made on the geometric regularity of the villi described by Clara (1927b).

Neither the position of goblet cells in birds of different ages as Cloetta (1893) described nor the numbers of goblet cells as investigated by Ackert $e t$ al. (1939) were studied, nor was any consideration given to the cells of Paneth. Greschik (1922), Clara (1926b and 1927a) and Bradley and Grahame (1951) found them, while Cloetta doubted their presence.

The writer agrees with Retterer and Lelièvre (1910a) that areas were present which had the appearance of Peyer's patches but that no true Peyer's patches, as described by Otte (1928), were present.

Sufficient observations were not made to prove that lymph nodules were more abundant in one region of the intestine than another, only that they were observed in all sections from adult specimens studied. Batt (1925) found more lymph nodules in the duodenum than in the remainder of the small intestine.

The author agrees with Cloetta (1893) and Otte (1928) that the duodenum had the widest lumen of the small intestine, except in the 36-hour chick, in which the small intestine just beyond the duodenum was wider.

An iliac sphincter as described by Zietschmann (1911) was observed.

Much lymphoid tissue was found in the mucosa of the caeca of all birds studied except in the 36-hour chicks; and as I.ooper and Looper (1929) described, there were many lymph nodules. The lymphoid area was observed in the proximal portion of the caeca as described by severa! authors [Oppel (1897), Zietschmann (1911), Kaupp (1918), and Bradley and Grahame (1951) ].

Observation did not bear out the findings of Batt (1925) that the muscularis mucosae of the caeca was well developed, but agreed with Looper and Looper (1929) that it was absent in many places.

The blind ends of the caeca presented such a varied structure in different specimens that one can agree with either Zietschmann 
(1911) and Browne (1922) that the villi were short or absent, or with Batt (1925) that the mucous membrane was thrown into folds having the appearance of villi.

No particular attention was given to the goblet cells of the caeca except that they were present. Zietschmann (1911) stated that they were lacking where lymphoid tissue was plentiful.

Observations bore out the statement of, Looper and Looper (1929) that lymphoid tissue infiltrated the caeca with increasing age.

The rectum was similar in structure to the small intestine. The findings agreed with those of Greschik (1912) that the villi were the same height as those of the small intestine, that lymphoid tissue was present, and that the submucosa was weakly developed and in places not discernible.

The rectum was separated from the cloaca by a constriction in the circular muscle which might be termed a sphincter, according to Bütschli (1924), or a valvular circular orifice, according to Owen (1866) and Otte (1928).

The cloaca was divided into three compartments. Gadow (1891a), Schauder (1923), Thomson (1923), Bütchli (1924), Ward and Gallagher (1926), Bennett (1944), Chamberlain (1944), Bradley and Grahame (1951), Foust (1952), and Sisson and Grossman (1953) found the same.

The writer did not agree with Marschall (1895) that the anal opening was a horizontal slit. The lips of the vent met horizontally but the actual opening was a vertical slit.

This study agreed with that of Bradley and Grahame (1951) that the chicken liver contained tubules of epithelium, a cross section of which showed four to seven cells arranged around an intralobular bile capillary or canaliculus. Portal trinities and central veins were observed. Batt (1926) described central veins, but Zietschmann (1911) stated that they were lacking. Elastic fibers were found in the capsule of Glisson in addition to the vessel walls as Zietschmann observed them, and a reticulum was observed but not "scant" as Batt (1926) stated. Observations made on the color of the liver did not agree with those of Doyle and Mathews (1928), who stated that the liver changed frum a yellow color to a maroon at the age of one week to 10 days. The author found that the change took place at approximately 15 days of age. 
In specimens of gall bladder observed, there was an inner longitudinal and an incomplete outer circular or oblique layer.

Studies on the pancreas substantiated Clara's (1924) work that the pancreas had three lobes: dorsal, ventral, and splenic; and that the splenic lobe had no separate excretory duct. The presence of both alpha and beta islets as described by Nagelschmidt (1939) and Oakberg (1949) was confirmed. The writer agreed with Böhm (1904) that the islets of Langerhans were not set off from the surrounding tissue by connective tissue. Centroacinar cells were found, in agreement with Zietschmann (1911), Krause (1922), and Bradley and Grahame (1951).

The pancreatic ducts were similar to the bile ducts as Zietschmann (1911) stated.

Observations made on the remnant of the yolk stalk indicated that it is constantly present as Muthmann (1913), Latimer (1924), and Bradley and Grahame (1951) thought. It is a continuation of the intestine, and it becomes degenerated with age as Maumus (1902) observed.

The writer found a thin serosa in the bursa cloacae as did Osawa (1911). Involuntary muscle was present in its walls as Gadow (1891a) and Jolly (1915) observed. This muscle presented an outer circular and inner longitudinal arrangement as Osawa (1911) found. Retterer (1885) found the opposite. No blood vessels were observed in the medullary portion. Wenckebach (1889 and 1896) and Schumacher (1903) also made this observation. Schumacher's (1903) observations that the epithelium varied from cuboidal to tall columnar to pseudostratified types were verified. Goblet cells were present. Gadow (1891a) found them, but Wenckebach (1889) did not.

A valve was present over the opening into the bursa cluacae. Forbes (1877) could not find one, while Retterer (1885) observed one in the murre (Uria aalge).

\section{SUMMARY}

A microscopic study of the digestive tract with its appendages was made on chickens of different ages.

The general structure of the wall was as follows: a mucous membrane comprised of an inner epithelial lining, a tunica propria, and a muscularis mucosae; a thin submucosa; a lamina muscularis with an inner circular muscle layer and an outer longi- 
tudinal muscle layer; and an outer adventitia or serosa depending on the location of the organ.

The epithelium of the mouth contained many epihelial papillae which projected posteriorly. The muscularis mucosae was absent as far back as the caudal part of the pharynx. Uniformly constructed salivary glands were observed in groups in the submucosa.

Large mucous glands were present in the tunica propria of the esophagus. No glands were found in the diverticulum of the crop but were confined to the esophageal wall of that organ.

The stratified squamous epithelium of the esophagus changed into simple columnar epithelium at the junction with the proventriculus and continued as such as far as the anus.

The proventriculus contained mucosal plicae which were concentrically arranged about the openings of multilobular deep proprial glands to form macroscopic papillae. Between these papillae the plicae were irregularly arranged.

Between the proventriculus and the gizzard was an intermediary zone characterized by the disappearance of the deep proprial glands and surface plicae and the appearance of a keratinized inner layer.

The gizzard was characterized by a keratinized inner layer. Tubular glands, which emptied on the surface, were arranged in groups in the tunica propria. The lamina muscularis was a single layer of involuntary muscle.

The intestine from the gizzard to the anus, including the caeca, was characterized by villi. No Brunner's glands were present in the duodenum. No Peyer's patches were found.

The caeca contained many plicae circulares. The villi were low to absent in the blind end.

The cloaca contained many transverse folds and plicae circulares in its walls and exhibited three compartments.

The anus was lined with stratified squamous epitheliurn, and contained voluntary muscle in its walls.

The liver and the pancreas were similar in structure to those of mammals. The three pancreatic and the two bile ducts opened into the duodenal papilla.

The bursa cloacae was an organ of lymphoid-epithelial structure found only in chickens under one year of age. 


\section{LITERATURE CITED}

Ackerr, J. E., S. A. Edgar, and L. P. Frunk. 1939. Goblet cells and age resistance of animals to parasitism. Amer. Micros. Soc. Trans., 58:81-89.

AsнсRAFт, D. W. 1930. The correlation activities of the alimentary canal of the fowl. Amer. Jour. Physiol., 93:105-10.

Barthels, Philipp. 1895. Beitrag zur Histologie des Oesophagus der Vögel. Zeits. f. wiss. Zool., 59:655-89.

Batr, H. E. 1925. A study of the normal histology of the fowl. 1924 Report of the Ont. Vet. Coll., pp. 21-31.

1926. A further study of the normal histology of the domestic fowl. 1925 Report of the Ont. Vet. Coll., pp. 24-30.

Bayer, Morirz, 1901. Beiträge zur Histologie des Muskelmagens der Vögel. Arch. f. mikr. Anat., 57:653-76.

Baum, Hermann. 1930. Das Lymphgefässsystem des Huhnes. Zeits. f. d. ges. Anat. Abt. 1, 93:1-34.

Bennetr, Clare H. 1944. Relation between size and age of the fowl cloaca, bursa and gonads with special reference to growth and structural variations in their constituent parts from hatching date to sexual maturity. Thesis, Michigan State College, East Lansing, Michigan.

Berry, R. J. A. 1900. The true caecal apex, or the vermiform appendix: its minute and comparative anatomy. Jour. Anat. and Physiol., 35:83-100.

Bischoff, T. L. W. 1838. Uber den Bau der Magenschleimhaut. Müller's Arch. f. Anat. u. Physiol., pp. 503-25.

BitrNer, H. 1924. Die Sektion des Hausgeflügels und der Versuchssingvögel. Berlin. tierärztl. Wochenschr., 40:99-101; 111-15; 125-28.

Blanchard, C. E. 1860. Observations sur le système dentaire chez les oiseaux. C. R. Acad. Sci., 50:540-42.

Boetticher, Hans von. 1928. Beitrag zur Kenntnis der Morphologie und Phylogenie des hornigen Vogelschnabelüberzuges mit besonderer Berücksichtigung seiner Beziehungen zu den Schneuzenschildern der Saurier. Jenaische Zeits. Naturw., 63:455-558.

Böhm, Gustave. 1904. Beitrag zur vergleichenden Histologie des Pankreas. Inaug. Diss., Rostock.

BotEZAT, EUGEN. 1904. Geschmacksorgane und andere nervöse Endapparate in Schnabel der Vögel. Biol. Zbl., 24:722-36.

1906. Die Nervenendapparate in den Mundteilen der Vögel und die einheitliche Endigungweise der peripheren Nerven bei den Wirbeltieren. Zeits. f. wiss. Zool., 84:205-360.

Boyden, Edwarp Allen. 1922. The development of the cloaca in birds, with special reference to the origin of the Bursa of Fabricius, the formation of a urodaeal sinus, and regular occurrence of a cloacal fenestra. Amer. Jour. Anat.. 30:163-201.

Bradley, O. C., and Tom Grahame. 1951. The structure of the fowl. J. B. Lippincott Co., Philadelphia. 
Browne, T. G. 1922. Some observations on the digestive system of the fowl. Jour. Comp. Path. and Therap., 35:12-32.

BUJARD, E. 1906. Sur les villosités intestinales; quelques types chez les oiseaux. C. R. Assoc. Anat., 8. Réunion, Bordeaux, 25:I-23.

Büтschц, Отто. 1924. Vorlesungen über vergleichende Anatomie. Julius Springer, Berlin.

Cal houn, M. Lois. 1933. The microscopic anatomy of the digestive tract of Gallus domesticus. Iowa State Coll. Jour. Sci., 7:261-382.

CiazıN, M. 1885. Développement de la couche cornée du gésier du poulet et des glandes qui la sécrètent. C. R. Acad. Sci., 101:1282-84.

1886a. Sur la structure de la muqueuse du gésier des oiseaux. Bul. Soc. Philom., Paris, 7 th Series, 10:57-61.

1886b. Recherches sur la structure de l'estomac des oiseaux. C. R. Acad. Sci., 102:1031-33.

$1887 \mathrm{a}$. Contribution à l'étude des muqueuses gastriques. Congrès de Toulouse, Sept.

1887b. Sur le développement embryonnaire de l'estomac des oiseaux. Bul. Soc. Philom., Paris, 7th Series, 11:99-102.

1887c. Glandes gastriques à mucus et à ferment chez les oiseaux. C. R. Acad. Sci., 104:590-92.

1888a. Développement de la muqueuse gastrique. Assoc. Franc. Avan. Sci., 17th Session. P. 192.

1888b. Recherches anatomiques, histologiques, et embryologiques sur l'appareil gastrique des oiseaux. Ann. Sci. Nat., Zool., 7th Series, 4:177-323.

Chamberlain, F. W. 1944. The digestive system of fowl. Unpublished manuscript. Michigan State College Experiment Station, East Lansing, Michigan.

Chauveau, Armand. 1905. Comparative anatomy of the domesticated animals. $\mathrm{D}$. Appleton \& Co., New York.

Chonnik, K. S. 1947. A cytological study of the alimentary tract of the domestic fowl (Gallus domesticus). Quart. Jour. Mícros. Sci., London, 88:419-43. 1948. Cytology of the glands associated with the alimentary tract of domestic fowl (Gallus domesticus). Quart. Jour. Micros. Sci., London, 89:75-87.

Cholodkowsky, N. A. 1892. Zur Kenntnis der Speicheldrüsen der Vögel. Zool. Anz., 15:250-58.

Clara, Max. 1924. Das Pankreas der Vögel. Anat. Anz., 57:257-65.

1926a. Beiträge zur Kenntnis des Vogeldarmes. I. Teil. Mikroskopische Anatomie. Zeits. mikr. anat. Forsch., 4:346-416.

1926b. Beiträge zur Kenntnis des Vogeldarmes. II. Teil. Die Hauptzellen des Darmepithels, 1-27. III. Teil. Die basalgekörnten Zellen in Darmepithels, 28-54. IV. Teil. Uber das Vorkommen von Körnezllen von Typus der Panthschen Zellen bei den Vögeln, 55-75. V. Teil. Die Schleimbildung im Darmepithel mit besonderer Berücksichtigung der Bercherzellen-Frage, 256-304. VI. Teil. Das lymphoretikulare Gewebe im Darmrohre mit besonderer Berücksichtigung der leucozytaren Zellen, 305-50. Zeits. mikr, anat. Forsch., 6.

1927a. Beiträge zur Kenntnis des Vogeldarmes. VII. Teil. Die Lieberkühnschen Crypts. Zeits. mikr. anat. Forsch., 8:22-72.

$1927 \mathrm{~h}$. Beiträge zur Kenntnis des Vogeldarmes. VIII, und letzter Teil. Das Problem des Rumpf-Darmschleimhautreliefs. Zeits. mikr. anat. Forsch., 9:1-49.

Clausen, D. M. 1953. Beitrag zur Phylogenie der Langerhansschen Inseln der Wirbeltiere. Biol. Zentralbl., 72:161-82.

Cloetta, N. 1893. Beiträge zur mikroskopischen Anatomie des Vogeldarmes. Arch. mikr. Anąt., 41:88-119.

Cornelius, C. 1924. Morphologie, Histologie und Embryologie des Muskelmagen der Vögel. Morph. Jahrb., 54:507-59.

Dalton, A. J. 1933. The ontogenetic history of the mitochondria and Golgi network of the hepatic cell of the chick. Anat. Rec., 58:321-39.

Dawson, A. B., and S. L. Mover. 1948. Histogenesis of the argentophile cells of the proventriculus and gizzard of the chicken. Anat, Rec., 100:493-515. 
Doyle, L. P., and F. P. MAthews. 1928. The pathology of bacillary white diarrhea in chicks. 1ndiana Agr. Exp. Sta. Bul., 323. July.

ElJas, Hans, 1945. Comparative histology of domestic animals. I. The digestive system. 3. Oesophagus and stomach of domesticated birds. The Middlesex Veterinarian, 4:1-6.

and Herbert Bengetsdorf, 1952. The structure of the liver of vertebrates. Acta Anatomica, 14:297-337.

Ellenberger, W., and H. Baum. 1943. Handbuch der vergleichenden Anatomie der Haustiere. Edited by O. Zietschmann, E. Ackerknecht, and H. Grau. Julius Springer, Berlin.

Foot, N. C., and M. C. MenaRd. 1927. A rapid method for the silver impregnation of reticulum. Arch. Path., 4:21 1-14.

Foress, W. A. 1877. On the bursa Fabricii in birds. Proc. Zool. Soc., London, pp. 304-18.

ForsGren, ERIK. 1929. The anatomical qualities of the liver during the various stages of its functional activities. Jour. Morph., 47:519-29.

Foust, H. L. 1952. Chapter on anatomy of the chicken. In Diseases of Poultry, 3rd Edition (H, E. Biester and L. H. Schwarte), The lowa State College Press, Ames, lowa.

Franck, Ludwig. 1923. Handbuch der Anatomie der Haustiere. Revised edition by Martin, Paul. Lehrbuch der Anatomie der Haustiere. Schickhardt and Ebner, Stuttgart.

Gadow, Hans. 1879. Versuch einer vergleichenden Anatomie des Verdauungssystems der Vögel. Jenaische Zeits. Naturw., 13:339-403.

1891a. Cloake und Begattungsorganen. Bronn's Klassen und Ordnungen des Thier-Reichs. Aves: Bd. 6, Abt. 4:845-63.

$1891 \mathrm{~b}$. Verdauungssystem. Bronn's Klassen und Ordnungen des ThierReichs. Aves: Bd. 6, Abt. 4:590-713.

GARRoD, A. H. 1872. On the mechanism of the gizzard of birds. Proc. Zool. Soc., London, April 16, pp. 525-29.

Greschiк, Jenö. 1912. A madarak vegbelenek mikroskopiai anatomiaja. Mi. kroskopische Anatomie des Enddarmes der Vögel. Aquila, 19:210-69.

1922. Uber die Panethschen Zellen und basalgekörnte Zellen im Dünndarm der Vögel. Aquila, 29:149-55.

Grossman, J. D. 1927. Some anatomical features of the fowl. Ohio Vet. Alum. Quart., 15:27-35.

Halnaw, E. T. 1949. The architecture of the avian gut and tolerance of crude fiber. Brit. Jour. Nutrition, 3:245-53.

Hässe, C. 1866. Beiträge zur Histologie des Vogelmagens. Zeits. f. rat. Med., 28: $1-31$.

HedeniUs, Israel. 1892. Chemische Untersuchung der hornartigen Schicht des Muskelmagens der Vögel. Skand. Arch. Physiol., 3:244-52.

HeIDRICH, K. 1905. Mundhöhlenschleimhaut und ihre Drüsen bei Gallus domesticus. Diss. Giessen. (Published in Morph. Jahrb., 37:10-69, 1908.)

HibвaRD, Hope. 1942. The "Golgi Apparatus" during development in the stomach of Gallus domesticus. Jour. Morph., 70:121-36.

Hoepke, Hermann. 1930. Histologische Technik der Haut. Julius Springer, Berlin. P. 184.

Hollis, W. A. 1901. The joint in a fowl's tongue and its vocal function. Jour. Anat. Physiol., 35:413-15.

Holting, H. 1912. Uber den mikroskopischen Bau der Speicheldrüsen einiger Vögel. Diss. Giessen.

Huxley, T. H. 1878. A manual of the anatomy of vertebrated animals. Appleton, N. Y.

InbE. 1912. U'ber angebliche Zahnanlagen bei Vögeln. Arch. mikr. Anat., 79: 247-75.

IVEY, W. D., and S. A. EDGar. 1952. The histogenesis of the esophagus and crop of the chicken, turkey, guinea fowl and pigeon, with special reference to ciliated epithelium. Anat. Rec., 114:189-212. 
Johnston, W. T. 1920. Digestive organs of the chicken. West Wash. Mo. Sta. Bull., 8.

Jolly, J. 1910. Sur les premières phases du développement de la bourse de Fabricius. C. R. Soc. Biol., 69:493-95.

1911a. Histogénése des follicles de la bourse de Fabricius. C. R. Soc. Biol., 70:422-24.

1911b. Sur la fonttion hématopoiétique de la bourse de Fabricius. C. R. Soc. Biol., 70:498-500.

1911c. Sur l'involution de la bourse de Fabricius. C. R. Soc. Biol., 70:56467.

1911d. Sur les modifications histologiques de la bourse de Fabricius, dे la suite du jeâne. C. R. Soc. Biol., 71:329-25.

— 1913a. Sur les oganes lympho-épithéliaux. C. R. Soc. Biol., 74:54043.

— 1913b. L'involution physiologique de la bourse de Fabricius et ses relations avec l'apparition de la maturité sexuelle. C. R. Soc. Biol., 75:638-40.

__. 1915. La bourse de Fabricius et les organes lympho-épithéliaux. Arch. Anat. Micr., 16:363-547.

-, and S. LEvin. 1911. Sur les modifications de poids des organes lymphoides à la suite du jeûne. C. R. Soc. Biol., 71:320-23.

Kalurus, E. 1905. Beiträge zur Entwicklung der Zunge. 2. Teil: Vögel. Anat. Hefte, 28:305-586.

KaupP, B. F. 1917. Poultry diseases. 2nd Edition. Amer. Vet. Pub. Co., Chicago.

- 1918. Anatomy of the domestic fowl. W. B. Saunders Co., Philadelphia.

1921. Alimentary canal of birds. Vet. Med., 16:23-26.

Kersten, August. 1912. Die Entwicklung der Blinddarm bei Gallus domesticus unter Berücksichtigung der Ausbildung des gesamten Darmkanals. Arch. mikr. Anat., 79:114-75.

Kullan, G. 1888. Über die Bursa u. Tonsilla pharyngea. Morph. Jahrb., 14:618711.

Kingsbury, Janet W., Virginia G. Allen, and Barbara A. Rotheram. 1953. The histological structure of the beak of the chick. Anat. Rec., 116:95-116.

KingsLex, J. S. 1917. Outlines of comparative anatomy of vertebrates. Blakiston, Philadelphia.

Jatein, E. 1871. Osophagus und Magen. In Stricker's Handbuch der Lehre von den Geweben des Menschen und der Thiere, 1:497-559.

Kovacs, Julius. 1928. Comparative histologic studies upon the oral and anal parts of the intestine of the domestic fowl. Közleményck az osszehasonlító élet-és kórtan köréböl., 21:400-405. Abstract in Jahresbericht veterinar. Med., 1:56.

Krause, Rudolf. 1922. II. Mikroskopische Anatomie der Vögel und Reptilien. Verl. Gruyter, Berlin-Leipzig.

KupFer, OTto. 1908. Uber Kropfoperationen bei Tauben and Hühnern unter Berücksichtigung der anatomischen und histologischen Verhältnisse. Inaug. Diss. Bern.

LARoche, N. and R. 1926-27. Contribution à l'étude des glandes de l'estomac. Arch. d'Anat. d'Hist. et d'Embryol., 6:187-99.

Latimer, Homer B. 1924. Postnatal growth of the single comb White Leghorn. Jour. Agric. Res., 29:363-97.

1928. Growth changes in the body and some of the organs of the chick at time of hatching. Anat. Rec., 39:215-28.

and John L. OsBorn. 1923. The topography of the viscera of the chicken. Anat. Rec., 26:275-89.

Leasure, E. E., and R. P. Link. 1940. The saliva of the hen. Poultry Sci., 19:19134.

LOOPER, J. B., and MARGARET H. LoOper. 1929. A histological study of the colic caeca in the bantam fowl. Jour. Morph. and Physiol., 48:587-98.

LUCAS, A. M. 1947. Intranuclear inclusions in the islands of Langerhans of chickens. Amer. Jour. Path., 23:1005-21. 
Magnan, A. 1911a. La surface digestive du ventricule succenturié et la musculature du gésier chez les oiseaux. C. R. Acad. Sci., 153:295-97.

1911b. La surface totale de l'intestine chez les oiseaux. C. R. Soc. Biol., 71: 617-19.

Mallory, F. B., and J. H. Wrisht. 1924. Pathological technique. W. B. Saunders Co., Philadelphia.

MAngol. E, E. 1931. Reported by W. P. Blount of Royal Vet. College, Edinburgh, in Continental Notes. Vet. Rec., 10:475.

Marschalx, W. 1895. Der Bau der Vögel. J. J. Weber, Leipzig.

MARSDEN, S. J. 1940. Weights and measurements of parts and organs of turkeys. Poultry Sci., 19:23-28.

MARSH, O. C. 1881-82. Birds with teeth. U. S. Geol. Survey, 3:45-88.

Maumus, J. 1902. Les caecums des oiseaux. Ann. Sci. Nat., Zool., Series 8, 15:1-148. and L. Launoy. 1901. La digestion coecale chez les oiseaux. Bul. Mus. Hist. Nat., 7:361-65.

Mayberry, M. W. 1935. Origin and development of the crop in the chick. Trans. Kans. Acad. Sci., 38:325-35.

McLeoD, W. M. 1939. Anatomy of the digestive tract of the domestic fowl. Vet. Med., 34:722-27.

Michalica, Josef. 1924. Uber das Vorkommen von Pflasterepithel in den Schleimdrüsen der Hühner. Wiener tierärztl. Monatschr., 11:55-67.

MILLER, R. A. 1942. Effects of anterior pituitary preparations and insulin on islet cells of the pigeon pancreas. Endocrinology, 31:535-44.

Moog, FLoRENCE. 1950. The functional differentiation of the small intestine. I. The accumulation of alkaline phosphomonoesterase in the duodenum of the chick. Jour. Exp. Zool., 115:109-29.

Moore, C. A., and Rush Elliotr. 1944. Numerical and regional distribution of taste buds on the tongue of the pigeon. Anat. Rec., 88:119-31.

MuthmanN, E. 1913. Beiträge zur vergleichenden Anatomie des Blinddarmes der lymphoiden Organe des Darmkanales bei Säugetieren und Vögeln. Allat. Hefte, 48:67-114.

NAGELSCHMIDT, L. 1939. Untersuchungen über die Langerhansschen Inseln der Bauchspeicheldrüsen bei den Vögeln. Jahrb. f. Morph. u. mikr. Anat., 45: 200-255.

Nrwton, Alfred. 1893-97. A dictionary of birds; Assisted by Hans Gadow with contributions from Richard Lydekker, Charles S. Roy, and Robert W. Shu. feldt. Pp. 16-17, 27-69, 189-90. A. \& C. Black, London.

OAKBerg, Eugene F. 1949. Quantitative studies of pancreas and islands of Langer-

w hans in relation to age, sex, and body weight in White Leghorn chickens. Amer. Jour. Anat., 84:279-310.

OPPEL, A. 1895. Uber die Muskelschichten im Drüsenmagen der Vögel. Anat. Anz.., 11:167-72.

1896-1914. Lehrbuch der vergleichenden mikroskopischen Anatomie der Wirbeltiere. Fischer, Jena.

OrR, Harry W. 1931. Personal communication from Dr. H. W. Orr, Stillwater, Oklahoma.

OsawA, G. 1911. Uber die Bursa Fabricii der Vögel. Tokyo Mitt. Med. Fac., 9: 299-841.

OTte, W. 1928. Die Krankheiten des Geflügels mit besonderer Berücksichtigung der Anatomie und der Hygiene. Richard Schoetz, Berlin.

OWEN, Richard. 1866. Comparative anatomy and physiology of vertebrates. Birds and mammals, 2. Longmans Green \& Co., London.

Pasin, A. 1930. Personal communication from Oskar Seifried of the Rockfeller Institute of Medical Research, Princeton, N. J.

Prluet, A. H. 1886. Sur quelques réactions des cellules glandulaires du gésier des oiseaux. C. R. Soc. Biol., 38:290-92.

Pugnat, C. A. 1897. Recherches sur 1'histologie du pancréas des oiseaux. Jour. Anat. et Physiol., Paris, 33:266-82.

Retrerer, E. 1885. Contributions à l'étude du cloaque et de la bourse de Fabricius chez les oiseaux. Jour. Anat. Physiol., Paris, 21:369-454. 
RETTERER, E. 1893. Sur la part que prend l'épithélium à la formation de la bourse de Fabricius, des amygdales et des plaques de Peyer. Jour. Anat. Physiol., Paris, 29:137-42.

and A. Lelièvre. 1910a. Bourse de Fabricius et plaques de Peyer des oiseaux. C. R. Soc. Biol., 69:114-17.

- 1910b. Modifications évolutives et régressives de la bourse de Fabricius. C. R. Soc. Biol., 69:169-72.

1910c. Structure et évolution du troisième caecum du canard. C. R. Soc. Biol., 69:394-37.

1913a. Nouvelles recherches sur la bourse de Fabricius. C. R. Soc. Biol., 74:182-85.

1913b. Homologies de la bourse de Fabricius. C. R. Soc. Biol., 74: $382-85$.

RIDDLE, O. 1928. Studies on the physiology of reproduction in birds. XXIII. Growth of the gonads and bursa Fabricii in doves and pigeons, with data for body growth and age at maturity. Amer. Jour. Physiol., 86:248-65.

RöseleE, M. 1929. Die Bedutung der Blinddarm des Haushuhnes für die Resorp. tion der Nährung und die Verdauung der Rohfaser. Zeits. Tierzüchtung und Züchtungs-Biologie, 13:281-310.

Rosenstadt, B. 1912. Untersuchungen über die Histogenese des Eizahnes und des Schnabels beim Hühnchen. Arch. mikr. Anat., 79:612-36.

Rubeli, T. O. 1890. Uber den Osophagus des Menschen und verschiedener Haustiere. Arch. wiss. prakt. Tierheilk., 16:1-28; 161-97.

Schauder. W. 1923. Anatomie der Hausvögel. In Martin's Lehrbuch der Anatomie der Haustiere. Schickhardt and Ebner, Stuttgart.

SChilling, S. T., and W. L. BLEecker. 1928. The absorptive rate of the reserve yolk in baby chicks. Jour. Amer. Vet. Med. Assoc., 72:618-26.

SChreiner, K. E. 1900. Beiträge zur Histologie und Embryologie des Vorderdarmes der Vögel. Zeits, wiss. Zool., 68:481-580.

Schumacher, Sifgmuno von. 1903. Uber die Entwicklung und den Bau der Bursa Fabricius. Sitzber. Akad. Wiss., Wien, 112 Abt., 3:163-86.

1926. Die Entwicklung der Glandulae oesophageae des Huhnes. Zeits. mikr. anat. Forsch., 5:1-22.

SHORE, T. W. and H. L. JONEs. 1889. On the structure of the vertebrate liver. Jour. Physiol., 10:408-28, 25:166-97.

Siufeldt, R. W. 1890. The myology of the raven. A guide to the study of the muscular system in birds. Macmillan Co. Ldt., London.

Sisson, Septimus, and J. D. Grossman. 1953. The anatomy of the domestic animals. W. B. Saunders Company, Philadelphia.

SjöGren, Sven Johan. 1945. Úber die Embryonalentwicklung des SauropsidenMagens. VI. Uher die Embryonalentwicklung des Vogelmagens. Acta Anat., Supp. II, 1:69-218.

StIEda, Ludwic. 1880. Uber den Bau und dic Entwicklung der Bursa Fabricii. Zeits. wiss. Zool., 34:296-309.

Strong, Reubin Myron. 1939, 1946. A bibliography of birds with special reference to anatomy, behavior, biochemistry, embryology, pathology, physiology, genetics, ecology, aviculture, economic ornithology, poultry culture, evolution, and related subjects. Zoological Series, Field Museum of Natural History 25: Part 1, Publ. 442; Part 2, Publ. 457, 1939; Part 3, Publ. $581,1946$.

Stirkie, P. D. 1954. Avian physiology. Comstock Publishing Assoc., Ithaca, N. Y. Sivenander, Gust. 1902. Studien über den Bau des Schlundes und des Magens der Vögel. Danske Selsk., pp. 1-240.

Thomson, J. A. 1923. Biology of birds. Pp. 98-110. Macmillan Co., New York.

WARD, A. R., and B. A. Gallagher. 1926. Diseases of domesticated birds. Macmillan Co., New York.

WEnckfBach, K. F. 1889. De Ontwikkelung en de Bouw der Bursa Fabricii. Nederl. dierk. ver. Tijdschr., Ser. 2, 2:19-138; 139-42. 
1896. Die Follikel der Bursa Fabricii. Anat. Anz., 11:159-60.

Wiedershem, R. E. 1872. Die feinern Strukturverhältnisse der Drüsen im Muskelmagen der Vögel. Arch. mikr. Anat., 8:435-52.

and W. N. PARKFr. 1897. Comparative anatomy of vertebrates. Macmillan Co., New York.

1907. Elements of comparative anatomy of vertebrates. Macmillan Co., New York.

Wilczewskr, Paul. 1870. Untersuchungen über den Bau der Magendrüsen der Vögel. Inaug. Diss. Breslau.

ZietschmanN, O. 1908. Uber eine eigenartige Grenzzone in der Schleimhaut zwischen Muskelmagen und Duodenum beim Vogel. Anat. Anz., 33:456-60.

1911. Der Verdauungsapparat der Vögel. In Ellenberger's Handbuch der vergleichenden mikroskopischen Anatomie der Haustiere, Paul Parey, Berlin, 3:377-416.

\section{ADDITIONAL REFERENCES}

The following citations are not included in the review of literature and have not been examined in all cases. It seems desirable, however, to make the compilation of literature as nearly complete as possible. Therefore, the following list of citations is included as an appendix to the list of reviewed literature.

Alesi, Vicenzo. 1875. Sulla borsa di Fabricio negli uccelli. Atti Soc. Ital. Sci. Nat., $18: 133-69$.

Arvey. 1651. Exercitationes de generatione Animalium. Amsterdam. Exercitatio VII (De Gallinge aliarumque avium ventre). P. 71.

Aulmanx, G. 1909. Mundrachenwand der Vögel und Säuger. Morph. Jahrb., 39: $34-82$.

Baistrocchi, E. 1886. Sopra un granuloma del proventricolo di una gallina con nota istologica sulla struttura normale dell' organo. $13 \mathrm{pp} ., 1 \mathrm{pl}$. Parma.

Balli, Ruggrero. 1907. Sul connettivo di sostegno dei muscoli lisci dello stomaco degli uccelli. Ricerche istologiche ed embriologiche. Monit. Zool. Ital., $18: 19-36$.

BaRkow, H. C. L. 1843. Disquisitiones recentiores de arteriis mammalium et avium. Acad. Caes. Leop. Nova Acta, 20:607-720.

1829. Von der Kloake verschiedener Vögel. Arch. Anat. Physiol,, Leipzig, $4: 443-50$.

BAsslinger, J. 1854. Untersuchungen über die Schichtung des Darmkanals der Gans, über Gestalt und Lagerung seiner Peyer'schen Drüsen. Sitz. Akad. Wiss., Wien, 13:536-55.

1858a. Die Peyer'schen Inseln (plaques) der Vögel. Zeits. wiss. Zool,, 9: 299-300.

1858b. Die Chylusgefässe der Vögel. Zeits. wiss. Zool., 9:301-3.

ВАтH, W. 1905. Untersuchungen über Geschmacksorgane einiger Vögel. Sitzber. Ges. naturf. Fr. Berl., 225-31.

1906. Die Geschmacksorgane der Vögel und Krokodile. Arch. Biont., 1:1-47.
BEDDARD, F. E. 1885. Notes on the visceral anatomy of birds. On the so-called omentum. Proc. Zool. Soc., pp. 836-44.

Belocolowy (BelorolovyJ), J. A. 1910. Une branchie préspiraculaire chez le triton. Sur la bouche chez les vertébrés. Biol. Zh. Mosk., 1:68-89; 90-92.

Berganann, C. 1862. Einiges über den Drüsenmagen der Vögel. Arch. Anat. Physiol. wiss. Med., pp. 581-87.

Berlin, W. 1852-53. Bijdrage tot de spijsvertering der vogels. Nederl. Lancet, 2: $57-68$.

Berthold, A. A. 1828. Uber den Fabricischen Beutel der Vögel. Acad. Caes. Leop. Nova Acta, 14:903-18. 
Bittner, Heinrich. 1925. Die Nasenhöhle und ihre Nebenhöhle beim Hausgeflügel. Berlin. tierärztl. Wochenschr., 41:576-79.

1925. Beicrag zur topographischen Anatomie der Eingeweide des Huhnes. Zeits. Morph. Oekol. Tiere, 3:785-93.

Вӧнм, L. 1835. De glandularum intestinalum structura penitiori. Inaug. Diss. Berolini.

Botezat, Eugen. 1910. Morphologie, Physiologie und phylogenetische Bedentung der Geschmacksorgane der Vögel. Anat. Anz., 36:428-61.

Boyden, Edward Allfin, 1919. The digestive tract of the five-day chick. Anat. Rec, $16: 143-44$.

Braitmaier, Heinrich. 1904. Ein Beitrag zur Physiologie und Histologie der Verdauungsorgane bei Vögeln. 42 pp., 1 Taf. Diss. Tübingen.

Brandt, J. F. 1885. Anatomie der Vögel. St. Petersburg, Russia.

BRENDEL, F. 1859. Anatomische Mittheilungen über verschiedene Vögel. Zeits. ges. Naturw., 13:449-52.

BruUn, A. voN. 1893. Verdauungsorgane. Ergebnisse Anat. Entw., 3:238-62.

Bunge, J. 1847. Einige Bemerkungen über den Ductus vitelli intestinalis bei Vögeln. Müllers Arch. Anat. Physiol., pp. 14-16.

BUJARD, E. 1908-09. Villosités intestinales; types anatomiques; variations expérimentales. Anat. Anz. Erg., 32:212-22.

1909. Étude des types appendiciels de la muqueuse intestinale, en rapport avec les régimes alimentaires. Morphologie comparée. Sitiomorphoses naturelles et expérimentales. Int. Mschr. Anat. Physiol., 26:101-96.

Campana, Artere. 1874. Essai d'une détermination par l'embryologie comparative, des parties analogues de l'intestin, chez les vertébrés supérieurs. C. R. Acad. Sci., Paris, 77:217-20. Ann. Méd. Vét., 23:43.

Carus, C. G., A. W. Otto, and J. S. E. Alton. 1826-1855. Erläuterungstafeln zur vergleichenden Anatomie, Barth, Leipzig. In 9 parts.

Cattaneo, G. 1883. Sull' istologia del ventricolo e proventricolo del Melopsittacus undulatus. Jour. de micrographie, Paris, 7:508-12; 571-76.

1884. Istologia e svilluppo dell' apparato gastrico degli uccelli. Milano, Soc. Ital. Atti, 27:88-175.

1885. Sulla struttura e formazione dello strato cuticolare (corneo) del ventricolo muscolare degli ucceli. Bol. Scient., 7:87-92.

1888. Intorno a un recente lavoro sullo stomaco degli ucceli. Pavia.

Chaine, Joseph. 1905. La langue des oiseaux. Étude de myologie comparative. Bul. Sci. Fr. Belg., 39:487-504.

Corti, Alfredo. 1912. Studi sulla minuta struttura della mucosa intestinale di vertebrati in riguardo ai suoi diversi momenti funzionali. Arch. Ital. Anat. Embriol., 11:1-189.

1923. Contributo alla migliore conoscenza dei diverticoli ceichi dell'intestino posteriore degli uccelli. Ricerchi di Morfologia, 3:211-95.

1923. Sul significato morfologico e funzionale dell'intestino ceco. Rivista di Biol., 5:187-205.

Curschmann, Heinrich. 1866. Zur Histologie des Muskelmagens der Vögel. Zeits. wiss. Zool., 16:224-35.

Custor, J. 1873. Ueber die relative Grösse des Darmkanales und der hauptsählichsten Körpersysteme beim Menschen und bei Wirbelthieren. Arch. Anat. Physiol., pp. 478-504.

Cuvier, G. 1805. Leçons d'anatomie comparée. 2nd edition, 8 vol. Crochard Paris.

DantschakofF, Wera. 1909. Untersuchungen über die Entwicklung des Bluts und Bindegewebes bei den Vögeln. Das lockere Bindegewebe des Hühnchens im fetalen Leben. Arch. mikr. Anat., 73:117-81.

Davidoff, M. v. 1887. Untersuchungen über die Bezichungen des Darmepithels zum lymphoiden Gewebe. Arch. mikr. Anat., 29:495-525.

Eberth, J. 1860. Uber flimmer Epithelium in Vogeldarm. Zeits. wiss. Zool., 10:379-82.

1861. Uber die Follikel in den Blinddarm der Vögel. Wurz. Natw. Zeits., 2:171-76. 
1862. Neue Untersuchungen über Flimmerepithel im Vogeldarm. Zeits. wiss. Zool., 11:95.

Fleischmann, Albert. 1924. Der Rumpfhang (Splanchnon) der Wirbeltiere. Untersuchungen zur vergleichenden Systematik der Eingeweide. Zeits. Morph. Oekol. Tiere, 2:505-66.

FLower, W. H. 1860. On the structure of the gizzard of the Nicobar pigeon and other granivorous birds. Proc. Zool. Soc., Part XXVIII pp. 330-36.

Forkes, W. A. 1888. Remarks on Dr. Gadow's papers on the digestive system of birds. Jbis, 4:234-37.

Forssner, H Jalmar. 1907. Die angeborenen Darm- und Oesophagusatresien. Eine entwickelungs-geschichtliche und pathologisch-anatomische Studie. Anat. Hefte, 34:1-163.

Fraisse, Paul. 1880. Uber Zähne bei Vögeln. Wurzburg. Phys. Med. Ges., 15:iii-ix. Fürbringer, M. 1888. Untersuchungen zur Morphologie und Systematik der Vögel. 2 Bande. G. Fischer, Jena \& Amsterdam.

GaDow, H. 1869-71. Vögel in Bronns Klassen und Ordnungen des Tierreiches. C. F. Winter, Leipzig. Bd. 6, Abt. 4.

Gallen, W. 1871. Ueber die Bursa Fabricii. Inaug. Diss., Dorpat.

GARDINER, E. G. 1884. Beiträge zur Kenntnis des Epitrichíums und der Bildung des Vogelschnabels. Arch. mikr. Anat., 24:289-338.

GaSSER, E. 1880. Die Entstehung der Cloakenöffnung bei Hühnerembryonen. Archiv Anat. und Entwicklungsgesch., pp. 297-319.

Gegenbaur, C. 1874. Grundriss der vergleichenden Anatomie. Engelmann, Leipzig.

Geofrroy St. Hilaire, E. 1821. Système dentaire des oiseaux. Ann. Gén. Sci. Phys., 8:373-80.

Gieber, C. 1858. Die Zunge der Vögel und ihr Gerüst. Zeits. ges. Naturw. 11:19-50.

GILLETrE, E. P. 1872. Description et structure de la tunique musculaire de l'oesophage chez l'homme et chez les animaux. Robin, Jour. Anat. Physiol., 8:617-44.

Goette, Alexander Wilhelm. 1867. Beiträge zur Entwicklungs-geschichte des Darmcanals im Hümnchen. 82 pp., 4 Taf. 8vo. Laupp'sche Buchh., Tübingen.

GreschIK, JeNö. 1913. A madarak allalatti mirigyenek (Glandula mandibularis) szovettani, vizsgalata. Adlek a mucinkepzodes ismeretehez. Histologische Untersuchungen der Unterkieferdrüse (Glandula mandibularis) der Vögel. Ein Beitrag zur Kenntnis der Mucinbildung. Aquila, 20:331-74.

1914. A keratinoid-reteg keletkezese a madarak izmos gyomraban. Die Entstehung der keratinoiden Schicht im Muskelmagen der Vögel. Aquila, 21:99-120.

Gurin, G. I. 1911. Die Anatomie der Vögel. Moskva, Russia.

GurLt, E. F. 1847-1848. Anatomie der Hausvögel. Mag. ges. Tierheilk., 13:484-94; $14: 51-77,204-23,261-77,422-43$.

1849. Beiträge zur pathologischen Anatomie der Hausvögel. Mag. ges. Tierheilk., 15:72-84.

HaHn, E. 1830. Commentatio de arteriis anatis. 2 Taf. Hannover.

Heidrich, Paul Kurr. 1908. Die Mund- und Schlundkopfhöhle der Vögel und ihre Drüsen. Morph. Jahrb., 37:10-69.

Hellman, A. 1853. Einiges über das Zungenorgan der Vögel. Naumannia, 3:139 46.

Henry, K. M., A. J. MacDonald, and H. E. Magee. 1933. Observations on the functions of the alimentary canal in fowls. Jour. Exp. Biol., 10:15s-71.

Hrlzheimer, Max, ANd O. Haempel. 1913. Vögel, in Handbuch der Biologie der Wirbeltiere, 2 vols. F. Enke, Stuttgart. Vol. 2, Vögel.

Hомe, E. 1810. On the gizzard of grazing birds. Philos. Transactions, 100:184-89. 1812. On the different structures and situations of the solvent glands in the digestive organs of birds according to the nature of their food and particular modes of life. Philos. Transactions, 102:394-404.

1814. Lectures on comparative anatomy. J. Lect. 3 \& 4 (On the digestive organs of birds). Lect. 5 (On the bills and gizzards of birds). G. \& W. Nicol and Longman, London. 
Huschke, Aemruus. 1838. De bursae Fabricii origine. Progr. Frommann, Jena.

[hNen, K. 1928. Beiträge zur Physiologie des Kropfes bei Huhn und Taube. I. Bewegung und Innervation des Kropfes. Arch. ges. Physiol. (Pflügers), 218:767.

IstVanfF, G. (Schanaschmidt). 1891. Recherche histologique comparée de la partie moyenne de l'intestin chez les oiseaux domestiques. Közlem. az összehason. élet-és kórtan köréb öl., 23:Fasc. 5-6.

Jä́kEL, A. J. 1873. Ueber das Ausstossen der inneren Magenhaut bi den Vögeln. Zool. Garten, 14:225-27.

Jefrries, John Amory. 1883. The epidermal system of birds. Proc. Boston Suc. Nat. Hist., 22:203-40.

Kahlbaum, C. 1854. De avium tractus alimentarri anatomia et histolgia nonnulla. Inaug. Diss. 29 pp. Gedani. Berolini.

Kaden, L. 1936. Uber Epithel und Drüsen des Vogelschlundes. Zool. Jahrb. Abt. Anat. Bd. 61 .

KAISER, H. 1925. Beiträge zur makro-und mikroskopische Anatomie des Gänse- und Tauben-Darms. Deutsche tierärzt\}. Wochenschr. 33:729-31.

Kashchenko, Nikolal Feofanovich. 1887. Das Schlundspaltengebiet des Hühnchens, Arch. Anat. Physiol, (Anat. Abt.), 258-300.

Keibel, Franz. 1921. Der Schwanzdarm und die Bursa Fabricii bei Vogelembryonen. Anat. Anz., 54:901-3.

Krdd, Walter Aubrey. 1907. The sense of touch in mammals and birds with special reference to the papillary ridges. $x+176$ pp., 164 figs., London. Zoologist, (4) ,11, 278 ,

KLein, JAcob TheODORE. 1759. Stemmata avium; accedunt nomenclatores: PolonoLatinus et Latinus-Polonus. A. H. Holle, Leipzig.

Klug, Ferdinand. 1891. Zur Kenntnis der Verdaụung der Vögel, insbesondere der Gänse. Zbl. Physiol., 5:131-35.

1892. Die Darmschleimhaut der Gänse während der Verdauung. Arch. Med., 1:114-17.

Krüger, AlFred. 1925. Beiträge zur makro- und mikroskopischen Anatomie des Darmes von Gallus domesticus mit besonderer Berücksichtigung der Darmzotten. Diss. Hannover. Deutsche tierärztl. Wschr., 1926:34, 112-13.

KuнL, H. 1820. Beiträge zur Zoologie und vergleichenden Anatomie. Hermann, Frankfurt.

Kutsuna, M., and Teruwo Kuriyama. 1932. Die Lymphgefässe des Kropfes der Hühner. Folia Anat. Jap., 10:423-27.

Lentitius, Rosinus. 1690. Gallina patulae ingluvies. Leopoldina (2), 8, 555.

I.EUCKART, F. S. 1841. Ueber zusammengesetzte Magenbildungen bei verschiedenen Vögeln. Zool. Bruchstïcke, 2:64-71.

Luvan, M. 1951. Lo sviluppo della ingluvie nell'embrione di pollo. Arch. Ital. Anat., 56:93-102.

LUCA, Ulderico DE. 1904. Ricerche sopra le modificazioni dell'epitelio dei villi intestinali nel periodo di assorbimento e nel periodo di digiuno. Boll. Acc. Med. Roma, 31:249-61.

LONNBERG, E., and L. JÄGERSKIOLD. 1890. Über das Vorkommen eines Darmdivertikels bei den Vögeln. Biol. Foren. Stockholm, 3:31-36.

Ludwig, Ferdinann. 1884. Ueber Endorgane der sensiblen Nerven in der Zunge der Spechte. Sitz-Ber. bayer. Akad. Wiss., 14:183-92.

1884. Zur Anatomie der Zunge. Eine vergleichende-anatomische Studie. 108 pp. 53 Taf. 4 to. T. Riedel, München.

I und, P. W. 1829. De genere Euphone, Praesertim de singulari canalis intestinalis structura in hocce avium genera. C. H. Roberti, Havniae.

Macartiney, J. 1811. An account of an appendix to the small intestine of birds. Philos. Transactions, 1:257-60.

Maccilluvray, W. 1837. Observations on the digestive organs of birds. Mag. Zoul. and Bot., 1:125-36.

Mangold, ERNST, 1906. Der Muskelmagen der Körner-fressenden Vögel, seine motorischen Funktionen und ihre Abhängigkeit vom Nervensystem. Arch. ges. Physiol., 111:163-240. 
Maumus, Jean. 1902. Sur le troisième caecum des oiseaux. Bull. Mus. Hist. nat. Paris, 36-38.

MAurer, F. 1902. Die Entuicklung des Darmsystems. Handbuch der vergleichenden und exp. Entwicklungslehre der Wirbeltiere, von O. Hertwig. 2, Teil I, p. 109. G. Fischer, Jena.

MAYER, A.F.J.C. 1841. Zähne im Oberschnabel von Vögeln, Krokodilen und Schildkröten. Notiz. Nat. Heilk., 20:69-70.

Meckel, J. F. 1821-1828. System der vergleichenden Anatomie. 6 Theile. 8vo. Renger, Berlin.

Mingazzini, Pio. 1901. Cambiamenti morfologici dell'epitelio intestinale durante lo assorbimento delle sostanze alimentari. Ricerche nel Lab. Anat. Norm. Università di Roma, 8:41-64.

Molin, R. 1852. Sugli stomachi degli uccelli. Denkschr. Akad. Wiss., Wien. 2 Abt., 3:1-24.

Monro, A. 1783. A treatise on comparative anatomy. London.

MüLlER, S. 1922. Zur Morphologie des Oberflächenreliefs der Rumpfdarmschleimhaut bei den Vögeln. Jenaische Zeits. Naturw., 58:533-606.

Nefrgand, Jens W. 1806. Vergleichende Anatomie und Physiologie der Verdauungswerkzeuge der Säugethiere und Vögel. $273 \mathrm{pp}$. Realschulbuchhandlung, Berlin.

Nuнn, A. 1875. Lehrbuch der vergleichenden Anatomie. C. Winter, Heidelberg.

Oppel, Albert. 1896. Die Magendrüsen der Wirbelthiere. Anat, Anz., 11:596-601.

OWEN, R. 1835-1836. Aves. Todd's Cyclop. of Anatomy and Physiology, 1:265-358.

Pensa, Antonio. 1906-1907. Della struttura e dello sviluppo dei gangli linfatici degli uccelli ("Anser domesticus") . Richerche nel Lab. Anat. Norm. Università di Roma ecc., 12:287-302.

Pilliet, Alexander Henri. 1889. Note sur la glande sébacée des oiseaux et sur le type glandulaire dans cette classe de vertébrés. Bull. Soc. Zool. Fr., 11522.

1893. Note sur l'appareil salivaire des oiseaux. C. R. Soc. Biol., 43:349 52.

1893. On the salivary apparatus of birds. Ann. Mag. Nat. Hist., 12:473-76. 1894. Sur les conditions qui determinent la forme du gésier des oiseaux. C. R. Soc. Biol, 46:639-40.

Postma, G. 1887. Bijdrage tot de kennis van den bouw van het darmkanal der vogels. Diss. Leiden.

Rapp, W. V. 1843. Ueber die Tonsillen der Vögel. Arch. Anat. Physiol. wiss. Med., 19-23.

RAwitz, B. 1894. Grundriss der Histologie. Karger, Berlin.

REICHEL, P. 1883. Beiträge zur Morphologie der Mundhöhlendrüsen der Wirbelthiere, Morph, Jahrb., 8:1-72.

Riuter, Fridericus Ludovicus Julius. 1820. De lingua mammalium et avicum quaedam. Diss. Köningsberg. 40 pp. 8vo. Regiomonti.

ROSENBERG, L. E. 1941. Microanatomy of the duodenum of the turkey. Hilgardia, $13: 623-54$.

SAINT-Remy, C. A. 1893. Recherches sur le développement du pancréas chez les oiseaux. Rev. biol. Nord Fr., 5:449-57.

Schumacher, Siegmund von. 1921. Darmzotten und Darmdrüsen bei den Waldhühnern. Anat. Anz., 54:372-81.

1922. Die Blinddärme der Waldhühner, mit besonderer Berücksichtigung eigentümlicher Sekretionserscheinungen in denselben. Zeits. ges. Anat., I Abt. 64:76-95.

1925. Ueber die Entwickelung der Oesophagusdrüsen beim Huhn. Verb. Anat. Ges. Jena, 34:58-62.

SEESSEL, A. 1877. Zur Entwicklungsgeschichte des Vorderdarms. Arch. Anatt. Physiol. (Anat. Abt.), 449-66.

SrYFERT, G. 1897. Beiträge zur mikroskopischen Anatomie und zur Entwicklungsgeschichte der blinden Anhänge des Darmkanals bei Kaninchen, Taube and Sperling. Inaug. Diss., Leipzig. 
Shufeldt, R. W. 1890. Myology of the raven. Macmillan \& Co., London.

SuPpeL, W. 1907. Das Mundaach der Vögel und Säuger. Gegenbaurs Morph. Jahrb., 87:490-524.

SJöGREN, S. J. 1941. Uber die Embryonalentwicklung des Magens beim Huhn. Morphol. Jahrb. Bd. 86.

Sol., UGo. 1906. Sulla struttura delle fibre muscolari liscie dello stomaco degli uccelli. Anat. Anz., 29:586-91, 1 fig. Bigliogr. anat., 1907, 17:25-52, 2 figs.

Stannius, F. H., and C. Siebold. 1846. Lehrbuch der vergleichenden Anatomie der Wirbeltiere. II. Teil. Veit u. Comp., Berlin.

Swenander, G. 1899. Beiträge zur Kenntnis des Kropfes der Vögel. Zool. Anz., 22: $140-42$.

Szymonowicz, L. 1926. Sur une nouvelle variété des corpuscles de Merkel chez les oiseaux. Bull. histol. appliq. Lyon, 3:225-29.

1930. Sur les terminaisons nerveuses de la langue du perroquet. C. R. Soc. Biol., 103:431.

Teichmann, Max. 1889. Kropf der Tauben. Arch. mikr. Anat., 34:233-47.

Tiedemann, F. R. 1810-1814. Anatomie und Naturgeschichte der Vögel. Bd. I, II, III. Heidelberg.

and Leopold Gmelin. 1831. Die Verdauung der Vögel. Verdauung nach Versuchung, Bd. II: 96-272; (Nachschrift) : 273-79. 4to. K. Gross, Heidelberg and Leipzig.

TовıAs, L. 1869. Uber das Ausstossen der inneren Magenhaut bei den Vögeln. Zool. Garten, 10:189-90.

Torukata, Y., and T. Shindo. 1923. Uber die Entwicklungsgeschichte der Darmzotten beim Hühnerembryo. Verh. jap. anat. Ges., 28-30. Jap. Jour. Med. Sci., 1925:2,21.

Trautmann, A. 1907. Beiträge zur vergleichenden Histologie des Dünndarmes der Haussäugetiere. Inaug. Diss. Zurich.

Unzertig, H. 1912. Über die Einwirkung der Röntgenstrahlen auf die Bursa Fabricii und einige Organe junger Hühner. Anat. Anz., 42:22-24. Arch. mikr. Anat., 1913, 82:380-407.

VAN Campenhout, E. 1933. The innervation of the digestive tract of the 6-day chick embryo. Anat. Rec., 56:111-18.

VaughN, V. D. 1876. Osteology and myology of domestic fowl. Sheehan and Co., Ann Arbor, Michigan.

Vigorita, Domenico. 1906. Sulla costituzione e genesi dello strato cuticolare dello stomaco muscoloso degli uccelli. Boll. Soc. Nat. Napoli, 19:193-216.

VIRCHow, H. 1891. Der Dottersack des Huhnes. Internat. Beiträge zur wiss. Med., $1: 223-53$.

VoGT, C., and E. YUNG. 1888-1894. Lehrbuch der praktischen vergleichenden Anatomie. 2 Bd. F. Vieweg and Sohn, Braunschweig.

WAGNer, R. 1837. Beiträge zur Anatomie der Vögel. Abhandl. Bayr. Acad,, 2:271308.

WERER, E. H. 1850. Uber die periodische Farbenveränderung, welche die Leber gewisser Hühner und der Frösche erleidet. Ber. Verhandl. K. Sachs. Ges. Wiss. zu Leipzig., 50:15-28.

Werer, M. A. 1902. Quelques faits concernant le développement de l'intestin moyen et de ses glandes annexes chez les oiseaux. C. R. Soc. Biol., 54:1268-69.

Wiedersheim, R. 1885. Lehrbuch der vergleichenden Anatomie der Wirbeltiere. Jena.

G. Fischer, 1909. Vergleichende Anatomie der Wirbeltiere. G. Fischer, Jena.

Wiktorow. Zur Morphologie des Muskelmagens der Vögel und über den Bau seiner Muskulatur. Uvon Sapiski Kasansk, weterin instit., 21:294.

Willink, TJEknk. 1899. Die Zahnleisten und die Eischeiden bei den Vögeln. Nederland Dierk. Ver. Tijdschr. Ser, 2, 6:243-54.

Wor.FF, C. F. 1768. Uber die Bildung des Darmkanals in bebrüteten Hühnchen. (Uebersetzt von J. F. Meckel, Halle, 1812.)

YARRELL, W. 1826. On the small horny appendage to the upper mandible in very young chickens. Zool. Jour., 2:438-37. 